\title{
TWRS Safety Program Plan
}

\author{
Linda M. Calderon
}

Caw Ratirinod

August 1996

Prepared for the U.S. Department of Energy

Assistert Secretary for Ervirommental Management

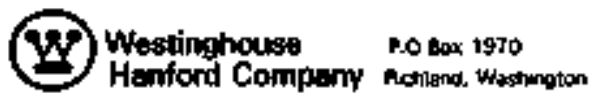

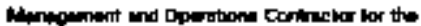

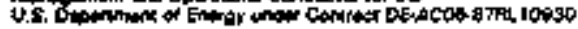

Approved for public release; distribution is unlimited 
THIS FAGL AN FENTIONALLY

LETT BLANK. 


\section{RELEASE AUTHORaZATION}

Dooumen Number: $\quad$ NHK-SP- 1185

Document Jite: Twas safety Program Plap

Rollest Cott: $\quad 8 / 30 / 96$

This document was reviewed following the procedures described in WHC-CM-3-4 and is:

APPROVED FOR PUBLIC RELEASE

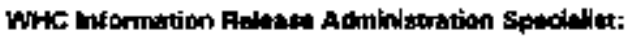

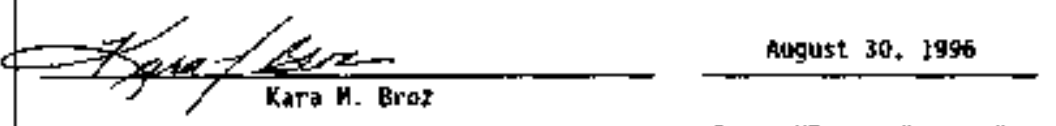




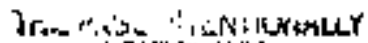
LE Y Y BLAN 


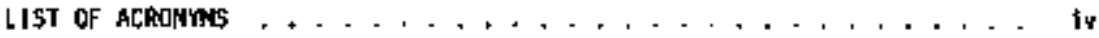

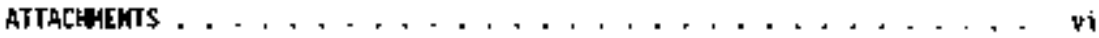

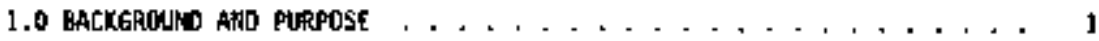

2.D STANDARQS HO IMPLEMEKTIKG POLIEIES , . . . . . . . . . . . . . ?

2.1 DRIVING STANQARDS $\ldots, \ldots, \ldots \ldots, \ldots, \ldots, \ldots$

2.2 IHPLENENT INW POLICY - . . . . . . . . . . . . . . . . . . . . . . 2

2.3 TNRS SAFETY CHARTER. . . . . . . . . . . . . . . . . . 4

2.3.] Charter Statement.................. 4

2.3.2 TWRS Safety Responsibilities . . . . . . . . . . . . . . 4

3.0 MAYOR PROCRAH ELEMENTS $\ldots, \ldots, \ldots, \ldots$

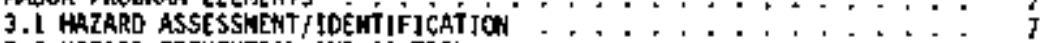

3.2 HARRRD PREVENTIOM AMO CONTROL . . . . . . , , . . . . . .

3.3 RECOROXEEPIHG . . . . . . . . . . . . . . . . . g

3.4 SAFETY ALARENESS AND PRONOTION . . . . . . . . . . . . . . . . . I]

3.4,1 Safety Counc115......., . . . . . . . . . . 11

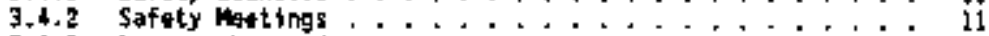

3.4 .3 Lessons Learnęd . . . . . . . . . . . . . . . . . . 12

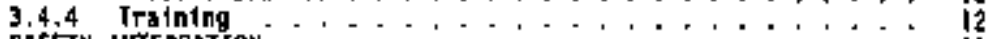

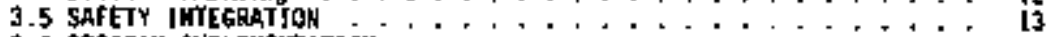

3.6 PAOGRAM JNPLENENTATIOH ....................... I

3.7 SPEC]AL PROGRAMS - . . . . . . . . . . . . . . 13

3.7.1 DOE Voluntary Protection Program (VPP) : . . . . . 13

3.7.2 Reduct ton of Worker Risk through Enhanced Hork PJanning. J4

3.J.3 Occupational Safety and Health S1 andards/Requirenents Identification Dociment (OSH $5 / R I O) \ldots . . . ., 14$

3. T.4 Nanagement Assessment Progran.............. 14

3.7,5 Faclitity Evaluation Board [FEB]. . . . . . . . . . . . . is

4.0 ORGAWIZATIONAL STRULTURE AND RESPOKSIBILITIES , . . . . . . I

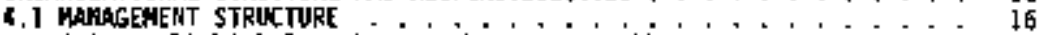

4.1.1 Field Safety Groups $\{$ East, West, top . . . . . . . . 16

4.1 .2 Thes Safety Core Group . . . . . . . . . . . . . . , , 17

4.1 .3 Safety Center of Expertise . . . . . . . . . . . 18

4.2 QUALIEICHTIONS AND RESPGNSIBILITLES . . . , . . . . . . 18

4.2.1 TARS Safety Managers . . . . . . . . . . . . J

\$.2.2 Safety Tean leads....................... 19

4.2.3 Industrial Hygiene Professionals and Technticlans.... 20

4.2.4 Industrial Safety Professionals , . . . . . . . . . 23

4.2,5 Fire Protection professionals .............. 25

4.2.6 Nuclear Safoty Professionals . . . . . . . . . . . . 26 
5 O PAOGRAM INTERFACES

5 I SAFETY CENTER OF EIPERTISE (COE)

52 HAMFORO EMYIROHEEMTRL MEALTH FOUROATIOH (HEHF)

5 3 ThRS LESSANS-LEARHEO PROGRAH

$5 \$ 00 E-R L / H Q \quad 30$

5 S COAPORATE MESTIMGHOUSE

56 DEF ENSE WUELEAR FAC ILITIES SAFETY COARD \{DWFSB〉

57 STHTE AND FEOERAL REGULATORY AGENTIES

5 B WORKER SAFETY ALD HERLTH SUB-PAHEL COWITTEE (SUb-TAP) \$\$

59 HANFOAO FIRE DEPARTHEMT

6 O RESOURCES

61 EQUIPNENT RESCURCES

62 STAFFIMG

63 GULGET/MORK BREAKDOWR STRUCTURE (HBS)

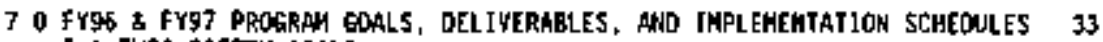

7 I TWRS SAFETY GQALS 33

72 TEL IVERABLES

73 SAFETY PROGRAM JHPLENENTATION PLANS/SCHEDULES

8 O PATH FOAWHAS

81 PROGRAH EMPHASIS 34

8 1 Document Review 34

6 12 Carcinogen Cantrol Progran 34

a 3 Hazard Compunication

1 4 Lead Control

1 5 Ergonomics

a 16 Mase/Hearing Consarvation

Q 17 Confined Space

6 18 Chẹmical Hygiẹne Plạn 36

82 THRS SAFETY CORE GMOUP PATH FORLARD

Q 2 \& Adrinistratiof and ONersight Activities and Deliverables 37

a 2 Industrial Hygrene Activitios and Del iverables

823 Industrial Safety Activities and Deliverables 3

824 Fire Protection Activities and Peliverables

B 25 Nuçear Safety Activities and Deliverables

826 Heaith and safety Progras Euphasis 40

B 3 CHARACTERIZATLGN OPERATIONIS (SAHPLING) PRTH FORWARD

8. ANGLYTICAL SERVICES SAFETY PATH FORWARD

841 Fundimg and terrient Workload

a 4 Path Fonward Activities 47

6. 5 UEST AREA SAFETY SEPPORT PATH FORWABD

8 G EAST AREAIEYAPARATOR SAFETY SLPPORT PATH FOANARD 
9.0 TRANSITIDN ISSUES /IMPLEKENTATIAN \$CHEDULES . . . . . . . . . . 55

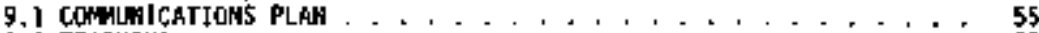

9.2 TRAINING

9.3 PRQNECT OMERSHA . . . . . . . . . . . . . . . . . . 56

9.4 RECOROS MANABEHEMT . . . . . . . . . . . . . . . . . . 56

9.5 BACK-UP RESOURCE5 , . . . . . , . . . . . . . . . . 57

9.6 IORKSCOPE PRIORITIES - - . . . . . . . . . . . . . . . . . . . 5 7

9.7 OVERT IRE - INDUSTRIAL HYGTENE TECHALCIANS . . . . . . . . . . . 5]

9.8 ON CALL LIST = JNDEASTRIAL HYGJEME . . . . . . . . . . . . . . . . . 58

9.9 DISSERINRT [ON OF EQU]PHEKI . . . . . . . . . . . . . . . . . . S\$

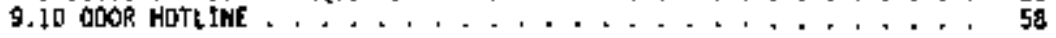

10.9 PRQGRAY PRIORJTIES . . . . . . . . . . . . . . . . . . . 54

11.0 REFEREHCES .......................... 60 


\section{$\therefore$ A AZSE INTENTIONALLY}

LEFT BLANK. 


\section{LJST af MCROHYHS}

\begin{tabular}{|c|c|}
\hline 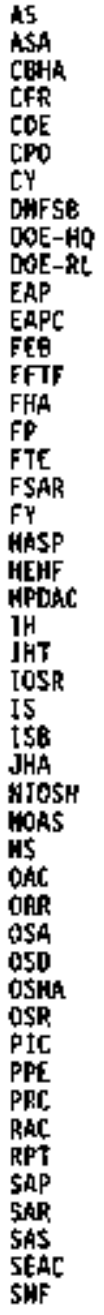 & 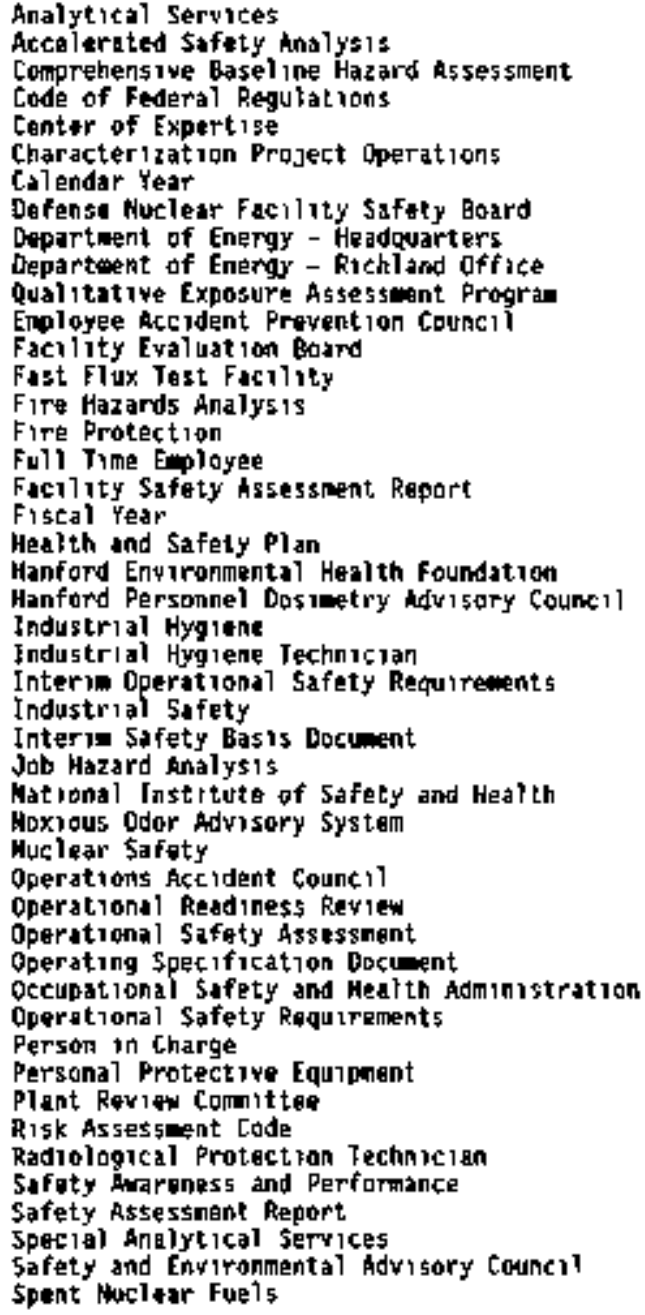 \\
\hline
\end{tabular}




\section{C[ST OF ACROHIHS (CONt)}

S/RID Standards/Raqu1 rements Identification Document.

Sub-TAP Work Safety and Health Subpanel of Waste Tank Adrisory Panel

SYF

TAP Synthetic Witreats Fiber

Inx

TSR

TFTP

ThRs

USO

vPP

NBS

MHC

USCF

High Level Waste Tank Advisory Panel

Training thatrix System

Technical Sofety Requirenents

Tank Far Transition Projects

Tank Wasto Reagdiation Systems

Upreviewed 5afety Question

Voluntary Protection Progran

Mork Breakdon Structure

Hest inghouse Hanford Company

Waste Sampling and Characterization Facility 


\section{ATTACHEETS}

Iank Waste Renediation 5ystems Organization Chart TWRS Safely Chain of Camand Organizalion Chart Industrid Mugfone Commenicstion Interface Chart industrial Safety Comunicat jon Interface chart fire Protection comuntcation Interfaçe chart Nuclear Safery Conimunication Interface chart Safoty Center of Expertisp Support Group Organtzation chart 7 Equlpeept Resources Document Revien Matrix ThRS Safety Core Group Administration and oversight sthedule 10 Core Group Industrial Hygiene Ioplementation Plan/Schedule i]

Core Group [ndustrial Safety Implewentation Plan/Schodule 12 tore Group Fire Protection Implementstion P1 sn/Schedula is Core Group Neclatar Safety Japlenenlation Plan/Schedu?e j4 Analytical Sorvices (AS) Safoty Profected Baselithe Narklaad - Frg? AS Safely Path Forward Activitios Implementation Plan/Schedule A5 Safety full Time Equiralęnt Sumary ל Safety Cosmunicat pons flow chart Cawounication with External Organizations Flow Chart 19 safety Center of Expertise Comunication channels flon chart 20 Docuent Review Floir Diagram 


\section{HO PAGE INTENTIONALLY LENT BLANK.}




\subsection{BACKENOUND ALD PURPOSE}

Manłgewent of Nuclear Safety. Industrial Safety, Industrial Hygigns, and Fire Protection programs, functions, and figld support resources for Tank Waste Remediation Systems (Thks) has, unt 1 ) recently, been centradized in ThRS Safety, under the Emergency, Safety, and quality organization. Industrial hygiene technician services were al so provided to support operational needs related to safoty basis compliance bue to $H C$ decentralization of safety and reanglneering efforts in West Iatak farbs staffing and safety responsibilities have been transforred to the facilities

Under the naw structure, safety personnel for IHRS are assigned directly to East Tank farms, Wost Tani Fares, and a core Safety Group in TURS Enginasing. The tharacterization Project Operations (CPD) safety organization wip reain in tact as it currentiy exists Personnẹl assigned to East Iank Farns, West Tank Farms, and $[P 0$ will perform facilily-specific or project-specific dutios and provide field implementation of prograns Those assigned to the core group will focus on activities having a TuRs-wide or orogramat ce focus. Hanford-wide attivities will bo the responsibility of the Safoty center of Expertise In order to ensure on effective and consistent safety program for This undar the new organization program functions, gaals, organizational structure, roles, rosponsibilities, and path forward aust be clearly established

The purpose of the TNR5 Safety Progran Plan is to define the oyerall safoty program, responsibilities, relationships, and comitunicalian linkages for safety parsonelel under the new structure ln addition, issues associated with reorganrzation transition aro addressed, roclading training, project omership, records nanagement, and dissewination of equipunint

For the purpose of this docunent "Thas Safety" refers to all safety" orofessionals and techolcians \{lndustriai Safety, Industrial Hyglene, Fife Protection, and Nuclear Safety) within the ThRs organization, regardiess af theor location in the organization 


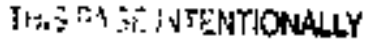

EETT BLANK, 


\subsection{STMOARDS NO LHPLENENTIMG POLJCIES}

\subsection{DRIVIMS STALOARDS}

The mission of Tank Maste Rewediation Systems is to store, treat, and

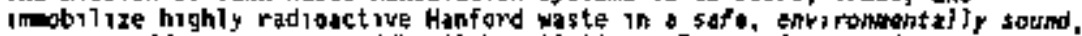

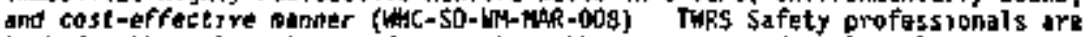
tasked with implementing and supporting the prograns and applicable requl rements of Industrial 5 afety, Industrial Hygiene. Fira Protection, and Nuclear safety withrn Thats to support this mistion in accordance with requirements and regulations as set forth in the DOE-approved TNRS Standards/Requirements Identification Docubent \{S/RIO\}.

\subsection{JPLLENETT Tha MOLICY}

The inglementing policy for the above standards is defined in Hestinohouse

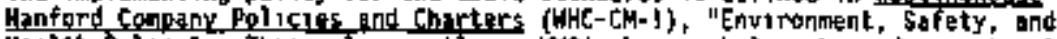

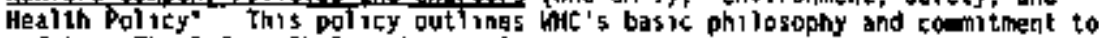
safety. The Safety Philosophy and tamitment stateoents (below) provide. basis for Thes Safely responsibajities, and give diroction to what the overall organization is trying to achieve Mussions and risions of safety organizations within HiC stem from these rdeals, and melp to define the path formard for the TWRS Safety Progran

\section{Wik sofoty Philosophy}

- If Its not safe, don't do it

- All oceupationd injuries and plinesses are preventable

- Safety is everyone's responsibitity

- Working safely is a condition of employment

\section{Wilc Combent}

- Conduct aill actuvities safely

- Comply with safety and environeental requirenents

- El relisate undue rist to people or the onviromanst

The TWRS Safety Charter (Section 2 3) inciudes the charter stateant, autharity, and orerall responsibilitits of TWFS Safety The responsibilities and suthority are genaral gundel jnes and apply to safety personnol in both the core and fietd organizations. The Core Safety Group prouldes cagrdination to ensure oragrans and actirities are consistent throughout TWRS. 
Specific Industrial Safely, Industrual Hyglene, Huckear Safety, and Fire Protection prograns and policies are furlher developed and defined in the following Nest inghouse Hanford Manuals

- Industrial Safety hanual (hat-Ch-1-10)

- Fire Protection hanual (Wic-C(k-4-4I)

- Huclear Criticality Safety Nanual (inC-CM-4-29)

- Safety Anabysis Handal (WhC- $(\$-4-46)$

- Industriaj Hugiene Manua75 [WHC-CH-1-1] and MHC-CM-4-40) Marual

WHC-CH-d-40 will be Incorparated into WHC-CH-1-II during 1995

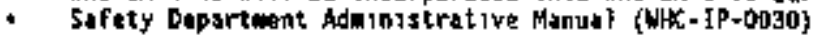

While it is not expected that any hit requirements conflict with the Turs $5 / R I D$, it such s case, the $5 /$ AID governs 


\subsection{TURS SAFETY CHARTER}

\subsection{Charter stateant}

The Thas Safety organization (Core, East, West, and [PO) provides profossiona) sufety servicas to tha TWRS Project throwgh integration, oversight, and support to creste and wantaln a safe and healthy working onvirosment while achleyrng suctess in the characterization, treatment, 5torago, and disposal of waste Through identifying. evaluating, and conlroli ing risk, the safety. protection, and well-being of personnel will be managed at acceptable levels in compliance wh appropriate Federal, DOE, State, and local statutes. regulations, orders, and contractual obligations

\subsubsection{TWRS Sufaty Responsibilities}

TWRS Safaty is responsible for maintaining an organization staffed and qualified to implenent the requiremenls and/or recomended practicas based on the U 5 Departeent of Energy [DOE] 5400 and 5480 Order Series, WHC 5 afaty Requirements, Safety basis foccuents, and the applicable sections of the Hanford 5ite Mandgement systes plans and documents (1 F Fiscal Year Workplans and TWRS Nulti-Year Program Plan) To fulfill this responsibility. Turs 5afety is responsible for tha following

1) Provide safety and health expertise, assistamie and support for TNRS operations and octivities

(a) Ant icipate tarards through independent safety reylen and approval af safoty documentat ion (plans, procedures, new or codified designs, safety analysts, work packages, purchase requisitions, safety requirenents) prepared by WHC, Project $A / E^{\prime}{ }^{\prime}$, and sub-contractors Nake reccemendations to mangement rugsrding appropriate controls for anlicipatted hatards

(b) Provide gerdance, consulization, and interpretalion of safety related orders, national standards, desıgn criteria, and impltanenting prograns and procedures

(c) Rssist TwR5 fanagement with development and Impleatent at on of health, safety, nuclear, and fire prolection plans, systems, controls, procedures, and trsintiag, and conduct hazard avaluations, risk and yses, and self-assessments

(d) Participate in safety integration activities such os safaty councils, lessons learned, task tears, and awareness activities to proxote safety and health implentation and performance

(e) Provide guidance, review, and approval in the developnent of peisits (1 E , Job Hazard And lysis, Conf ined Space Entry, Excavat 1on, and Asbestos) 
(f) Prouide technical expertise to assist in the preparation of accident/incident investigation reports

(9) Provide consultation to Thas on all aspects of tank waste rewediation efforts upon request.

2) Provide Inderstral Hyglene and Safety lechnical assistance and 5 upport through quslitat 7 ve and quant itative assassmants

(a) Ensure safety and health records are properly alnialned, coordination betweęn organizations and subcontractors occurs. employetes and subcontraclors are notified of results of inspections. industrial hyolene monitoring is provided, and applicable investigations are perforeed

(b) Hssist in the procurament of services for health and safety engineerimg, chenical exposure nonitoring, rospiratory protection, and safety traing Anticipate chemical exposures through procurement request resiew of all hazdrdous chencicals

3) Monitor TRRS safety and health to assess progran effectiveness and define performante and trends

(a) Participate in aodits, appraisals, inspections, and survelllances of plant facilities, operations. subcontractor activities, and equipont to assess compliance to ostablithed standards and requirements

(b) As approprate, resolve coeplaints, eaplayed concerns, and adyerse conditions related to safety and heal th through advice, investigat ions, andior direct resolution

(c) Prepare and issue summery roports ind trend aralysets

4) Provide Nuclear Safety expertise, assistance, vuer\$ight, and support for Tuhs operations and activities

(a) Ensure raste tank and support facilities have institutod an effective Unreviewed Safety Question (USO) Program

(b) Ensure raste tank façlities have a carrent and adechately defined safety bases

(c) Provide an independent detereination of wether a proposed nuclear activity involves an 050

(d) Participate in readiness reviews

(e) Ensure Technical Safaty Reowirenents TSA5 (curręntly operational safoty requirewents (DShs) are effectively icolonented 
(f) Ensture that nuclear critucality safety is maintained in Thas operations

(9) Proulde drect support in the impleantation and developinent of the Twh5 Finai Safely Analysis Report which complies with DOE Order 5460 23, Nuclear Safety Andiysis Aeports

5) Admister prograns to contral and ornieize hoslth snd safely hazards and promote continuous improvenent in health and 5 afety performance throughout INRS operations

(a) Advise management of the resources dpersonnel, budget, equopoent, time, heded to maintain an adequate safety profram

(b) If authorized, conduct research and developmint in areas essential or beneficidi to the TURS safety program and subalt the resuits for peer evaluation and publicat ion

(c) Coordinate the safety progran and proyide support to the programs of other Twhs and Safety departments, wajntain a professional rapport with these departments

(d) Prescribe appropriate hazard provention and conlral measures, and interpret data to assess and define acceptable levels of worker axposure to potentialiy harardous waterials or conditions

(e) 1nterface, as needed, with on-site contractors, subconeractors, and DOE-RL on safaty-related issues

\subsubsection{This Safety Authorjty}

Twas Safely authority includes l) access to records, Inforeation, property or plans to form good industrial safety, industrial hygiene, and nuclare safety judgemants, and 2) physical accass to all areas of the site to perform surveys, inspections, or other industrial safety and health related activities This includes access to managenent to recomiend adopting policios or actions detmed mecessery or dasirable for achieving the objective of the program (NOIE TNRS Safety persornel will abrda by the special qualifications or trajuing requirenents for entry into controlled areas )

In addition, ThRS Safely has the authority to assess the compliance of Thits organizations, operations, ard facilities, and subcontractor activitios with heslth and safety standards, to idenlify and document deficiencles that require corrective actions, and to follow-up for assurancB that corrective actions are taken if imeinent danger exists. TWAS Safety staff, 11k all ewpioyees, are authorized to direct that activities be stopped until the 155lues are reselved 
TME PLOSE INTENT:SNALLY

UEFT BLANKK. 


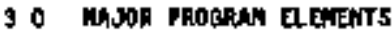

Sufoty profossionals for This are tasked with the responsibility of establisting a safe worksite through a combination of work controls. monitoring, and communication which are focused on achieving IwR5 objectives cost effectively, safety, and in compliance with established mic raquiroments The essential functions of the Thas Safety Program include

- Hazard k5 sossment/Jdent i fication

- Hazard Prevention and tontrol

- Recorokeeprng

- Safaty hwarent5s and Promotion

- Safety lntegration

- Progran Jepienantation

These elements are descrubed in the following subsections

\subsection{WLZAPO ASSESSIET/IDDETIFIEATION}

The purpose of hazard issessments in the work place is to qualitatively and quant thatively exaluate the extent of exposure and effectireness of control of accupat lonal safety and health hazards Ihis is required by DOE, OSHA and goad industrial hyglene and safaty practices Hazad assotstent: will be performed or essisted by a meater of ThRS Safety and includs the following

1) Analysis of new operations, prace5ses, watorials, or equipant. bofore insical use to detervine potential hazards These analyses w11 be performed in conjunction with Procurement, and the TNRS Enginger ing and operations organizations

a) Anatysis of any changes in operations, processes, materials, control oquipmont, work practices or porsonse] that have the potent ial to cawse new or additional hazardous exposures

3) Comprehensiye Baseline Mazard Assessengnts [CBHA\} of all areas and operations identified as having occupational he日lth apd safety hazards CBHA's are a systematic approach to ldentify work place hazards, evaluate controls and their offectiveness, and rerify inglementation of applicable 5 afoty and health ropulrements withan facility Facilities are reviewed by an integrated team potentialy consisting of Industrial Safety. Industrial Hograne, Fire Protection, Heath Physics, Dperations, and Safety Council Heabars

4) A conprehensive, qualitative characterization of the work place to recognize significant potential physical, biological, and ergonoeic exposures to workers Results of the analyses, professiond judgement, and trends IdenI Ifred through the characterization process will be used for prioritiang orogram emplasis, identifying 
further studies usugg the Qualitative Exposure Assessment Program (EAP), and establishing an induslrial tuggene moniloring schedufe

The pręliminary qualitative review of the EAp canșists of a survoy of an arganization The suryoy defines, through an inventory of stressors and tlme withis a workscope, how personnel are rated in respect to risk The exposure group 15 then defined and a risk assessment assigned An EAp and industrial hygiene monitoring schedule using a graded approach 15 then campleted

5) Quantitatiue monitoring of potentidiky hazardous exposures

(a) Personal montoring and sampling will be performed using brathing zonesupies that roflect the 8 hour Time Helghted Average, Short Term Exposure limit, or celling exposure of enployees as approprtate Sampling and analys 15 will be done in accordance with sampling and analylical methods specified by OSHA or HIOSH Analysis will be by a laboratory actredited by Ihe American [ndustrial Hyguene As $\$$ aciation for the general class of hezardous substance being analyzed

(b) Source wortoring idantifies potential sources of personnel exposure

(c) Area Monitoring is used to dotoraine exposure levels in the general work envaronment If a worker's pattern of potential exposure is well-defined, then knowledge of a worker's activity is sufficiant to estingte oxposure since this is not the case in tank fares, this is a qualutative tool that is a part of a conlete momioring program kroa monitoring may be used as ont of the indicatars to deteretne perssannel monitoring requirements

5) Spacific program audits, surverllances and self-assetsibents ( 1 e, crane safety, electrical safety, hazard communication) conducted to congrehęnșively rẹview isplementation and effect, irẹness of safety programs

7) Eraluation of compliance with safety, health, and fire protection requirements through both scheduled and unannounced field surveys of the work place

\section{HAZARD PREYEMTIOH AND CONTML}

The purpose of hazard prevention and controi is to timinate or mimmoze exposures or risk to occupational gafety and heatth hazards identified in the work place Thts is accomplished through substitution, engineering controis. use of work practuce controls, porsonal protective pquipand, or administrative controls TURS Safety will infore faciliky anagement of the 
control measures required to reduce $r i s k$ or exposure Control measures are recomemended in accordance with the fallowing hierarchy

1) Changling the procoss to less hazardous process or substituting the hazardous naterial with a less hazardous materrol

2) Isolating ar anclosing the process or operation

3) Implewesting engingering controls ( 1 e, ventilation, installation of sound absorbing material, otc )

4) Using adpintrative controls such as work practices or proceduras (1 6 Iimited access or rolating personnel to etnimize exposure)

5) Using personal protective equipment.

(a) Ust of respirstory protection during the time poriod nectssary to instak1, oyaluate, or repar engineering controls

(b) Use of personal protect ive equipment in work situations such as maintenance and repalr activities in wich frponesing controls are not feasibla

(c) Use of Dersonil protective equipment in work situations in whch engineering contrals and supplointal work practice controls are insufficient

(d) Use of personal protact uve equpment in energencses

Review of control effectiveness ustally occurs during the hazard assessment. phase of the baseline, special, or annual surveys lin addition to the traditional contrals described aboue, control of the workers' beharior through procedures, awareness training, and discidine $7 n$ mork performance is also necessary Hot all controls can be implemented inmadiately and reman within budgetary constraints of operations and site support organizations Using CBHA risk assessment codes (RAC 5 ), as $\$$ Decified in the CBhi procedure. nanegonent can ut 11 ize probabolity and frequency determinations as criterio natched againt the hazard severity for hazard abatement

\section{HECOROXEEPLH}

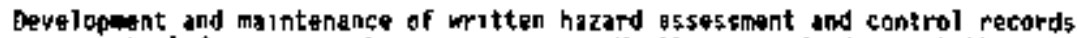
15 essential for a comprehensive progran Hriteen records document the operations descriplion and the results of hazard assesshents, including references to other documents used in the characterization of the work place, facility or enoloyee task They can also be used to ipform the staff of orevious studies or findings, determine trends, and wal idate effect iveness of controls Complete, accurate, and retriovable docueantation is essontial to prowade progf of hazard control 
Thas Safety wil ensure that hezard assessment, control, and site suruey records are accurate, coeplete, factual and in accordance with site documentation standards. Conclusions and recommendations oust be comunicatrod to the appropriate facility management and afferted personel for correclive attians. Exposure anitoring results aust be provided to affacted amployets whthn 15 days of recelpt of analysis result5 Der NHC-CH-4-40, Section 4,4, "Workplace Hazards Monitoring Requiremants."

As out lined in the OSHA field operating Manual, hazard assessment and control records should anclude the following'

1) Description of the operation, facility, or task and the results of the hazard assessment. including references to all docuastiotion usad to assist in choracterization of potential hazards.

2) Exposure monitoring records will identify emlayes considerad to be representative of the task being nonicored. Records should also include: location, date, duration, and nawer of sanples taken;; description of procedures used to deternine reprosentative sampling; description of saroling and anslytical wethods used; and a notation of any fonditions that way have influenced the sompling results.

3) A description or the spesific ne uns of compliante with applicabie OOE prescribed ardęs, OSHA and IHC requirements

4) A description of the control technology in place, to be installed, or that was considered, but not inplemented A schedule of abatement control measures should be recorded.

5) A progress report to affected organizations and DOE for the impleantation of hazard prevention and control neasures.

6) For those work operations and facilities whech do not represent a hazardolas exposure, the following should be provided to the affictod organization

(a) Doscription of any operation and results of the hazard assessment, including referente to docunentation used in the characterization and umque identifiers for all eaplayes essigned to the operation, and

(b) Awallable exposure monitoring records that contain the information listed in [2] above.

Field data generatad by industral hygiene technicians or plant industrial hygienists are reviewed for accuracy. comigleleness, and signed off by the TuRs 1ndustrial Hyg1enisl responsible for the facility or sctivity. Once reviowed, it 15 entered into a database, repprted to the organization and enoloyes anitored, as applicable, and then submitted to Industrial Hyglene Central safaty Group or filed with Tuks Safety according to type of form, survey, or 
site area Inspection reports will be generated as the surveys are conductod and trends w11 be identifiad gartorly

\subsection{AFETY MWRRELESS AHT TIONATION}

foployee accountability for safety in their workplace is established thragh offective safety awareness and promation Awareness of safety and health

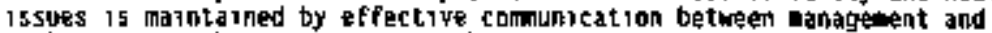
employees, and by gotting the enployoss involved in safety prograns It is a so promoted through employe recognition awards for gafety inyolvent, wheh are handled primarily through the safety councils The following subsections describe some of the wathods used to wantain safety wareness and pronote salety in the workplace

\subsubsection{Safety Counçi1s}

Each Twhs omploye is represented on one of the nune Employee Accident Prevention Councils, based on their organization and work area The purpose of the safety councils is to increase safety knowledge and awareness and instill sofety values through taployee participation the councils sre run by the eaplayess, and allow direct employes involvewent in safety activities and initiatives such as housekeptng inspections, safety improvements, sabediling safoty motings, and commumication/awareness activities some racent examles of safety coupicil accomplistiments include participation in the 1996 Safety Expo, initiating and performing personnel safety work package trending. initiat ipg walkway, steir, and llohting improwements, and prongting seat belt. usage The safety councils foster infomation exchange by providing forue for safety concerns to be volced, potenlial solutions addressed, and safety statistics provided to employess In addition, the counci15 spansor enployes recognition arards for excellence in safety and outstandimg participation in safety activities Additional tratining for countil pepbers 15 presently being proyzded in order to prowote are toumell involvenent in fundamental safaty issues such as hazard recognition

\section{3 d.2 Safaty Hotings}

Safety meetings are held each month for all Twks employees The mottings: promote safety by addressing a different hedith or sufety topit each month. including information on basic issues, control athods, and established progras Employees are encouraged to ask questions and participate in oach neeting by sharing their ideds on safoty isiues. The employed safety councils are responsible for schedviling the meetings, and aaking work tean assignments for sponsaring/developing the wonthly metings It is an expectstion within Twes to attain 100\% attendance at the safety meetings each month 


\subsubsection{Lessons Learned}

Conmunication of ingortant 5 afety inforeation 15 also provided through the lessuns learned program safety nolrces of lessons learned are publishead and distributed to facilities to inform parsonnel of aceidants or events that coukd potentially have a direct bearing on their workplace. The bulletins are based on it ems from within TWRS, areas around the Hanford site, and from external DOE and comercial sites, and include information on how 510 lar incidents could be prevented in the future. Section 53 contains additionsl infornation on the TuRs safety interface with the lessons leamed program.

\subsubsection{Training}

Iraining is the maln method of colmunication of safety information Iraining requirewents are established for each employee, bașd on the typo of work, work aras, and potential exposura to varlous hazards The requirements follow the precepts of the OSHh safety and heal th managenent guidelines and the implefuentation strategy of the site Voluntary Protection Program, and oro

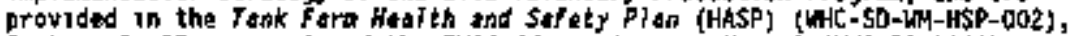

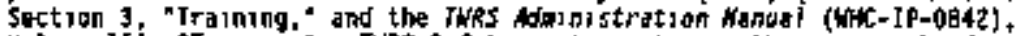
Yolume lil. "Traintig". TNRS Safety participatos in the process by developing and proylding training on heslth and safaty issues, and by onsuring safety profes510mals reain cognizant of current issues and changes/revisions to prograns and requirements. Some examples of training recently developod and provided to TWRS persomel include fall Protection, requirenent changes in the Industrial Safaty Maneal (Wik-(H-1-10), and Heat strest. In addition, every manager is requirad to attend Hanagenant Safety Iraining ovory year, Fequirod tratning for each employte is identified in tha Training Hatrix (JNX) Systea.

\subsubsection{J This Perșanntl Traitilng}

TWRS Safety recomends training to 1 ino eanagers on occupational safety and health hazards and nethods avallable to control exposure associated with various jobs Eeployees are trained in the detalls of the industrial safety. fice protection, and industrial hyglene programs and in the safoty and hoalth hezards associated with any job-related hazardous exposure Required Reading Prograns are al $\$ 0$ in piace for each line organization to ensure employees are kept current on pertinent issues such as manual updates, lessons laarnod, ind other safety related infureation

\subsubsection{Sufety Professional Training}

TWRS Safety staff are tranod in the anticipation, recagnition, evaluation, and controf of risk to ensure a level of competency to protect warker health and safety and ieplement all applicable provisions of draft oOE Order 5480.10A, Contrector Jndistrial Hyguene Progran, DOE OTder 5483. IA, Cont ractor

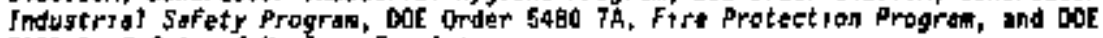

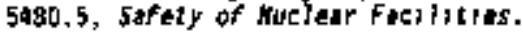


TKRS Safety prouides the nocessary support roquirod to maintzin and enhance stalf proficiency through continuing required site training and professional development Professional Deyelopaent Plans are developed for Thas safety professionals and technicians by their ling manageant The plans describe the courses or seminars suggested for each staff menter to enhance his/her growth as a professional during the year hecords shouing individuals' training and qualifications are verintained by the organnzation managetent.

\subsection{SAFETY JNTELRATIXW}

Safety lategration will occur through ownership and accountabjlity within al level 5 and departments of the TNRS organzation Visibility and participation at scheduled wetings and interfacing with key planning organizations is an essent ial elenent in safety involvewent [nnovatiqe awareness activities, ruports of safety perfornance, and fieid presence encourage integration This Progra: Plan seerves as a yehicle whereby TWRS Safety for East, West, cTo, and the 2225 jabs have an opportunity to establish a concerted affort to support Tuks safety The establishont of goals and objectives whereby we can achieve success as a unified effort are presented within the contents of this plan

\subsection{PROGKAH JMPLaMEGTATIOH}

The purpose of progran implementation is to ensure spplicable requirenents, regulations, and good safety principles are applied in the work plate. including dally work activities in the office or field and as\$oclated planming and follom-up activitios jt involves developing and iaplenenting training, providing guidance to employees in the basic pronciplas of safety prograns, performing hazard assessments and controls, and performing inspections and docuent reulews to ensure those principlos are applied Descriptions of some of the safety programs currently being emphasized within TNRS are proyded in section 80 , under the path forward for each group

\section{$3+7$ SPECIAL PROGAMVS}

The following subsections outline 5 pecial prograns ThRS 5 afety is participating in to enhance the safety progrant

\subsubsection{DoE Voluntary Protection Program (VPP)}

The DOE WPP 15 a recognition program built on the OSH4 Safety and Halth Progran Management Guidelines which represent a model for a proven effective safety progran WiL applied for nerlt status under the UpP in Mareh 1994 by subwiting an application which outlines the site initiatives that wet the critoria in the IPP guldelines Further information was requested by the coumittee, which was resubmitted in December 1994 To adrance the vpp princioles within This, a VPP stearing comittee is actively pursuing awarenes9, education, and integration initiatives To prepare for the DOE-RL 
Starbaso Hanford program, an application for local Ypp recognition for THRS facilleles will be propared and subulted during 199?.

\subsubsection{Roduction of Morker R1sk through Enhanced Mork Planning}

A phlot in 1995 for West Tank farns was designed to test and desunstrate basfi copabilities and practices that identify, address, and provide foedback on experience with work place hazands as part of a routine work planning process. Thes safety provided technital services to support this progran, Dering 1996 , this program was oxpanded to fit into the West Tank Farm Re-Engineering nodel for work olanning and is being tested within East Tark farms for decontaninat fon werk.

\section{J.3 DCcupational 5afoty and Health standards/Requiremonts Identification Docuent (OSH S/R1O)}

The Defense Nuclear Facilitios Sefoty Board (DWFSB) issued Reconmendation 90-2 whtch rocomonded that the ODE 1) identify specffic standards applicable to the design, construction, operation, and decomissioning of defonse nuclear facilities; 2) assess the adequacy of these standards for ansuring publy health and safety; and 3] for those standards that have been implenented, assess the extent of compliance.

Tank Fares has developed an S/RIO. The OSH S/RIO document, approved by OOE-RL in February 1996, identlfies the fac17tty and site level requirements in each of 19 functional areas necessary for protecting the health and safaty of the publite, the workers, and the environment. (The $5 / R 10$ does not cover the 2225 laboratories.') A Phase I assessment of the OSH $\$ / R 10$ inrolved revlewing thins and HaC docuentation for compliance with identified regulations, and was completed by TWAS safety on Narch 31, 1996. Phase II is a fie1d assesseant of conpliance, and is anticipated to be conducted during cross. Clarification of issues and responsibilities arlsting from the assessments will be addressed in โY96.

\subsubsection{Managenent Nasessment Program}

The Thes Hanapement Assessment Program was developed in accordsnce with Title 10 CFR 830,120 , which requires mangers to assess thejr maingement process. The progran is designed to integrate assessment schedules and uș restulting assessment data from prograns such as Operations and Haintenunce Champions, wanagemant observations, surveillances, and assesseents to provide the mans for effective trending andiysts. This aptimizes continuous taprovements in safety, qual ity. and operal iona 1 effictency throughout Thas activities. FWRS Safoty and huality assurance provides oversight of the TuRs Hanagenent issessment Prograe, and assists managers in ensuring duplication of assessments is eliminatod. TwRS Safety personnel participate in assessaents as requested. 


\subsubsection{Fatil try Evaluation Board (FEB)}

Factlity Evaluation has been eslablished to perform a11 WHC רodependent oversight using Facility Evaluation Bards (FEB). The FEB provides UHC facility and senior management with accurate, time $7 y$, snd consistont information to wasure a facility's effectiveness in coapleting its aission while assuring adherence to applicable conduct-of-operations, enviranmental, safeity, health, and quality assurance requsrements. Infornstion is obtarned through performance-based independent assessments of inc facilities, direct support activitios, and a comprehensive review of the facility's awn selfassessment proces5. In addition, facility Evaluation waj epssure that othar independent assessents, required by regulation or cont ract requirements, are porforned. TWRS Safety personnel ass $15 t$ FEB eaners with facility așessments. 
Th: = 1 r Blakk. 


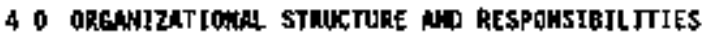

\section{MNAGEWEIT STRUCTURE}

Safety responsibilities are carrjed out at three levels for ToRS The Safety Center of Expertise (COE) mantains a site-wide (Hanford) perspect ive, responsible for development and maintenançe of coegany manua 15 , sns acting at the interpretive authorlty for requirewents and regulations The Ths Safety Core group trmlements safety polucies and programs at a ThRS-wride level, and helps coodinate faciljty-wde activities Fteld safety personnel twin East and west Tank Farh Projects) provide safety support to all facility-leval activities Field safety personnel withe CPO provide safely support to all 2225, NSCF, and 5A5 laboratory facility-leve\} (Analytical Servites 5afaty) and sappling (Characterization Project Safety) activities conducted at the Tank F a

\section{I F1010 5afoty Groups (East, West, CP0)}

Field-level personnel repart directly through the operations management chain in each area These are East Tank farms Safety and Quality Support under East Tank Farm Projects and Environmenta1, Radrologica1, and Safety Support under West Tank farm Projects Both support arganizations are matrixad to Thes Safely and Qualty assurance CPO safety professionals report to cPo Safezy and Quality Assurante, as part of the CPD line organization

The fleld safety groups w11l prougde technical safety support at the field leval The fieldulevel safety professiangls will support the facilitias in ioplewentstion of programs, mentor operational leavs in hazard recognition, support site specific document review (work packages, procedures, Jiks, and project documatation). but wore laportantly assure ihat safoly is initially bult into each docuent, Derfori facility inspectionsfwalkdowns, and provide general site safety support such as $1 \mathrm{H}$ field montoring, providing guidance on tralning and safety issues, and assisting with assessuents

The field-level safety professionals will be responsible for the activities listed below 0iscipline specific octivities are shown in Section 42 . Qualificalions and Responsibilities

- Provide facilily or Characterization Project-specific safety traingng and Hanford safety program trainung

- Participate in deveiopment/revien of faciilty-specific or Characterization Project 5pecific procedures, wark packages, support dorcumentation, and design reviews and projects

- Darticipale in fiejd-leyel Operational Readiness Reviews (ORR's)

- Perform hazard evaluations [including inspections, surveys, and walkdawns)

- Rssist anagoment with jncident/accident investigations

- Participate in lessons iearmed evaldations, and comunicate information to TwRS safety cora group 
- Provide facility-specific or Charactarization Project-specific information as necessary to support the Twhs Safety cors group ifor reports, trending, HASP updates, etc

- Provida inputiparticipate on monthly safaty meetings

- Prorida representatives as requested to internal camnittees (PAC, Safety Counc175, OAC)

- Assist in performing baseline and other apolicable assessments

- Assist management in implementation of TWRS Safety progracs at the facility and tharacterization Project levels

- [nterfaco with internat organizations on safety actirtties specific to ThRS facilities

\subsection{TNRS Safety Core Aroup}

Core group personnel report to the Tฟhs Safety Manager, under Thes safety and Quality Assurance ThRS Safety and Qubity Asturance and TaRs Safety are part of the Engineering line nanagement

The TWRS Safety Core Group wall coordinate deyeloponent of progran implewentation strategies, act as an interface with external organizations, coordinate fachlity-wide or progranitatit safety activitios, and provide firt protection engineering services to all Thas facilicies the core group wil also perform faciluty-wide safety oversight functions in the areas of data trencting, report coordind ion and development, and records managempnt

The This safety Core Group wil take the lead role in the actiyities Inted below Discipline specific activities are shom in section 2 . qualifications and Responsibilities

- Coordinate workable implementation strategies and impacts for COE

- Develop TuR5-wide training on safety prograns, 1ssues, and topics

- garticipate in development and raviaw of TWRS-wide docunents ard procedures (FSAR, S/RIB's, Safety dociments\}

- Malntain the Tank Fark Health and Safety Plan (HASP)

- Act as the Oxcupational Safety und Health \$/RIO and Fire Protection \$/RID functional area oumer, and perfore assaciatod assessoents as nectssiry

- Coordinate facility-wide project attivities

- Coordinate and perfore baseline assessuments

- Assist with invostigations of programatic issues (e 9 investigation of problen areas ident ified by trending'

- Coordinate TuRs-wide reports (Quarterly to DOf-RL and TwaS Managenent.

* Perfarm trending and develop and atinlain performance indicators

- bissaminste pertinent safaty information to field organizations

- Malatain rocords [?H monitoring records, trending inforwation] centrally with input proyided by field oroups

- Represent Tanks Fams and Enginaering on the Safęty Canter of Experlise

- Provide representalives ta interrnal cosal thees (EAPC, VPP, PRC, \$EAC, and the steering comaltee for Developing Operating Procedures)

- Interface with external organizations (\$ub-tAP, DOE-RL, EH Mentors)

- Provade Safely Awareness Award Coordijation 


\section{1.3 Safety Center of Expertise}

The Safety COE is external to the TWRS Drganization, but is an integral part of the This safety progran ks previously stated, the Safety cof mainlains a Hanford-wide focus, responsible for developing and maintaining company safety anuals and interfacing with requlatory agencies This includes the deuelopment of overall safety programs which are ralemented by core group and field personnel, and communication of new and rerised requirements

httachnent I depicts the managenent structure of the TARS Division At tachwent 2 shows the Thits safety chain of comand and personnei in Industrial Safety. Industrial Hrgiene, Fire Protection, and Nisclear safety Comaumication charts for each safety discipline are oroyidod as attachments 3 - 6

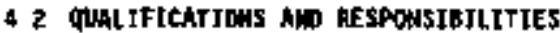

(Thas Safety Manaqur. Tean Londers, Industrial Hyolene, Industrial Safaty, Fire Protection, Maçloar Sofaty)

\subsection{Thrs safoty Mahagers (East/Mest/Cpo/Core)}

\section{2.1.1 Quepificakions}

Safety Nanager positions require a Bachelor of Sejence degrea in anginearing or science len (10) yedrs experlence in nuclear environment and at least 5 years of management experiance are needed In gddition, the Hanagers nust. have a clear understanding of 5 afety regulstions and their rolationships to nuclear and industrial safety and industrial hygene, have excellent communcation skilis, and the ability to identify problems and develop possible courses of action

\subsection{1+2 Responsidilities}

The Safety huagers provida managenent direction to the TNRS Safecy progran and profossionals in support of the oyerall TWRS wission This includes providing opportunities for effect pve integration and involyenent of professonals from Industrial safety and Fire Protection, Industrial Hygleng, and Muclear safety in dally Tank Farm activaties to idenlify and control hazards, and ensuring that all applicable DOE orders and regulations are 10p?emented In this capdeity. the mdnager enstres that there is an adequats number of professional staff in the various disciplines to carry out the oroanizational responsibilities outlined in the Tuks Safety Charter (Section 23 2], "TNAS Safety Responsibilities" The responsibilities listad below apply to Nanugers of East/Eycporator 5afety and Quality. Environnental, Radiological, and Safety Support, CPu safety and Quality, and the Tins Safety Core Group Nanagers Rasponsibilities that are not directly related to the rins Safety Prograg are not included 
- Implewent and maintain risk mamagent and safety awareness programs to establish a strong saFety culture and to keep eaployees informed of and alert to methods for winimizing occupational health and safety risks

- Assist Tank Farm facilities and attivities in achieving safe and compliant operations This is accomplished through the provisions dof industrial hyglene, safety, nuclear safety, and fire orotection expertise, assistante and servicas

- Recomend prograns to ldentify, control, and minimize or el upinate industrial, fire, nuclear, or recognizablę hẹith hązards

- Proyde hosith and safety serulces and support to the Safety cot for timely and effective resplution af safety incidents Ths includes investigating and reporting health and safety incidenț and concerns (as requestod), maintaining appropriate health and safety records. Crending and analyzing reports regarding health and safety experisnce, and directing or effectively recomending corrective and improvement setions

- Interface as needed with on-5ite contractors, subcontractors, and Dof on Tant Farm safety and health related program implenentation, experience, and records

- Recomend specific safęty goals and objectives for the group and measure the group's progress towards ach revements

- Develop professional staff expertise through supporting 5pecific traning and axperience and attending and participaing in continued education opportunities to mantain proficiency in the functionsi disciplines

- Recomand orogran polvey and guidance with advice provided by staff and senior anagement

- Recomend scope, schedule, and budget to achieve excellence in TuRs safety's functional responsibilities

- Act as the Tank Farm Safely and Health Representalive 5upervisor, as destribed it the Jank farm HASP

\section{2 sofety Tean Loghts (tast/Wast/cro)}

\subsubsection{Quplifications}

TWRS safoty Jean Leads must have Bachelar of Scaence degree in pccupational safety and health. fire protection, engineering, or a related field plus five (5) years experience, or equiralent edusation and experience Professional certification in the Tpa. Leaders' respective disciplimes, where applicable, 15 वाभ as\$et, but is not required Knowledge and understanding of applicabre regulations, orders, and standards, and how they apply to TwhS activities are a wust, in addicion to gaod camulication and problem solying skills 


\subsubsection{Responsibitities}

Ieab Leads provide project leadership and technical expertise to safety professionals and technicians as they support the ougrall TuRs mission This includes effectire integration and involyement of safety professionals in daly Iank farm activitias to identify and coatrol hazards, recomend effectlue correctsue and iaprarement actians, and winerze occupational health, safety, and fire risks Teat loads are responsibia for safety integration, inlementing safety and monitoring programs, mantaining progrạn records, and proyiding subcontractor oversight

In addition. Tean Leads support personnel developnent by establishing training plans of continued education, experience opportunities, and specific training to weet the orerall FWhS mission and commiteent to safety They also ensure personnel arg trained. knowledgeable and capable of performing the job requirements, and marntain proficiancy in thoir functional disciplines

\subsection{Industrial Hygiona Professignds ond Tochnicians}

\section{2.3.1 Quei ifications - Industriai hogiend Professionais}

Entry level requirenents for an industrial hygienist include a eachelor of Scietace Degree from an accredited college or university in engineering. chemistry, physics, medicine, ar rolated biological science Requrentents for being a fully quslified Safety Professiand include completion of the

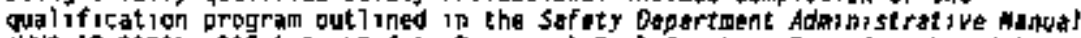
(Wt:-IP-0030\}, SAF-1 2, 'Safety Personnel Qual ification Procedure,' and two years of related experience

\subsubsection{Industrial Hygien Profossional Mesponsint1ities - General}

The fallowing are responsibilities of all TuRs Jndustrial Hyglenists, regardless of their posicion in the organization structure Specific dutieg assorclated with field and core tean industrial hyglene personnel are 1isted separately

- Eratuate and document potential exposures and assess effecliveness of control mathods

- Conduct surveys, assessments and self-assessments to identify, document, and evaluate potential wark place hoalth hazords

- Communicate recormendations to Jine managenent and other support organizations to protect morkers frce chemical, physical, biological and erg̣onomic work stressors

- Attend and participate in continuing education opportunitues to maintain proficiency in the discipline 
- Retomend compliance strategles with current corporate and governithental regulations, and accepted industrisl hygrene practice in ali the aross of responsibilities listed Industrial Hygremisis must provide for the mainlenance of adequate records of such surveys and inspections and for reparting the results to the appropriat personnel and other interested parties, and not ify the organizations of any conditions obseryed requiring the ir at tention

- [aplewent and revise as needed a progran for periodit suryey and inspection of Tank farm Transition Projects (TFTP), wheh covers both physical facilities, programs, pracedures, and operations to vdentify and address any hazards, conceris, or undestrable conditions.

- Assist manageant whe and follow-up on investigations of accidents and incidents

- Conduct field surveys of designded areas in response to requests or complalnts from managenent. TWRS personnel, OOE, or other governmental regulatory agencies

- Maintain records of inspections and surveys in order to report results and followup on compliance and correclive actions and to prounde trend andlyges to determine areas of concern and monitor performance indicators

- Evaluste the adequacy of prescribed health and safety procedures and the levels of protection provided for the acturl condituons in the field

- Participate in multi-diseipline sofoty reviews of designis and documents to as5e5s compliance with andated standards and recommended practices

- Participate in pre-job pianning through imvolvement in work site eqaluations, job control documentation preparation and review, and prejob briefings

- Integrate and promote safety within TWAS, supporting TNAS safety counci15. committeos, and reylew boards

\subsubsection{Qualifications - Industrud Hygiene Technicians}

Industrial Hyglęne Technicran's (fHTs) must haye a high school diplona, and one (j) year of experience in hatith and safety relatad orograms An As socinte of Aris/Scipnces degree in Industrial Hygiene or related tople ay be substituted for experience $1 \mathrm{HT}^{\prime}$ 's wust a1 \$o pass all phases of a comprehehsive training progran as spectified in the Sefety Department adennistrativo Handa) (NLC-IPD030). Twas-1 1. "JWRS Safety Industrial Hygiene Technician Qualification Plan," prior to morking independently in the field 


\subsubsection{IHT Rosponsibilities - Genorsl}

The folkwing are responsibilities of all TWRS IHTs, regardless of their location in the organization structure specific duties as50ciated with ficld and core team tadustriai hyglene petsonnal are listed separately

- Qperate a variety of industrid hygiene dirett reading instruments, including those used for detecting framable gases, oxygen, total organic yapors, ind specific chemical contaminants

- Collect eeasurements for physgcal and chemical hazards such as norse, 11 umination, ventilation, chemical vapors, and gases

- Perform routine industrial hyglene surveys to anticipate, identify, eraluate, and control potential hẹalth hazards

- Record and compute moatoring and samping measurements and results

- Perfore mantonsnce on instrunents, includimg cleaning of psrts and replacement of defective compononts

- Respond to urgent heulth and safoty conterns on an on-call basis

- Work with TWhS schedulers and field personnel ta provide industrial hyglene and sofety field support for Tank Farm work activities, inciuding dally demand work and spectal projects

- Wark with TWAS Safoky proftssionals to help develop strategles for ar oonttoring and sampling, provide timeiy colitction of data. submit wonloring sumbarles and reports, and comomicata field issues that affecl worker health and safety

- Attend, support, and participate if the industrial hyglene and safety technologist training prograc in arder to continesily improve efficiency.

\subsubsection{Cort Tean Inderstrial Hyglene Mctivities}

- Implement the IH Iechnician Iraining Prograe

- Develop Iraining for JH prograss and sile-wide issues

- toordinate PIC tralsing with TFTP Iraining organization

- Coordinate development of JH progran loplgeentation stratagies

- Parlicipate in derelopwent/perform 1H review of ThRs-level documents (S,PIOS, FSAR)

- Revien Thers-wide procedures and project docunentation

- Nantain the Tank Farm Hasp

- Participate in tochnical safety 15sues/review (05Ds)

- Develop/astribute temperature extreme alerts

- Restarchireview potential new instrumentation/technologies

- Provide IH suppart seruices for ThRS administration inon-ared specific personnel) 
- Coordinate or assist in performanco of baseline assessments isaurce monitoring. identification of personnel wh exposure pokential, and personal sampling

- Perfor 1H trending

- Perfor source swaps

- Proulde IH Eonitoring for [PO and Disposal organization actirities

- Provide backug resources for field groups

\subsubsection{Freid Industriel Wrgione Aetivitios}

- Provade facility or tharacterization Project-specific training on IM prograns and is aus

- Review alintenance and operating procodures and facility or Characterization Project-specifit project docinent ution

- Prowde fH input to work package planning and revien [JHAs and job walkdowns)

- Perform Occupancy Readiness Revions

- Participace in facility or Characterization Project-specific Operational Readrness Revrews

- Perform Dermitting activities/aporayal (esbestos, confined spaces)

- Assist with accident/incident invęstigations

- Prescrube respiratory prolect ion

- Interact with IH Core group in baselimng effort

- Maintain compl lance pragram 〈squrçe monitoringfotrsonnel sanplingł

- Perform breatbing zone sampling and job-specific IH eonitoring

- Interpret and roport monitoring and sampling measurements and results

- Inpul monitoring data to database and perform data reviek

- Notify employees, their superyisurt, and the Thks safety Core group of personal montoring results

- Participate in facility safety councils and the oAC

- Participate inforovide input for onthly 5 afety metings

- Provide miscellaneous IK support le g providing gurdance on hygiane issues and resolving concerns)

\section{2,4 Inddistriat sofety Professianals}

\subsubsection{Qualifications}

Entry leyel requirements for an industrial 5 afety (IS) professional include s Bachelar of sciente degree from an aceredited collepe or university in engimeering or rulatad scientific discipline Requrements for being a fuly qualifiod \$afaty Professional include congletion of the qualification program putlinad in the safety Departient dininistrative Nanual (WHC-IP-0030), SAF. 12 , "Safety Personnel qudlificalion Procedure." and two years of related experiance 


\subsubsection{Industriat Safety Professionsl Rosponsibilitios - Genera]}

The following are responsibilities of all TWR5 Industrial Safety orofessionals, regardloss of their position in the organrzation strutture. Specific duties as sociated with field and core tea industrial sofoty personnel are listed separately

- Inspect and evaluate plant facilities, operations, and equipint for compluance wath and enforcoment of applucable padustriaj safely codes. standards, and regulations

- Assist management with, and follow-up on investigations of accidents and incidents

- Conduct field surveys of designated areas in response to requests or complaints from manggement, ThiR5 personne1, DDE, or other govermwental regulatory agencies

- Hainta10 records of inspectrons and surveys in order to report results and follow-ep on compliante and corrective actions and to provide trend afalyses to determine areas of concern and wontor performance indicaters

- Evaluate the adequacy of preseribed hed th and safety procedures and the levels of protection provided for the actual conditions in the field.

- Participate in wulti-discipline safoty reviews of designs and dochents to assess compliance with wandated standards and recomended practices.

- Participate in pre-job planining through involvewent in vork site evaluations, Job control docimentation preparation and review, and projob briefings

- Integrate and promote safety wrthrA TWRS, support ing TWAS safety costactls and contait tees and rerier botards, as requested.

- Het as a Site Safety and Health Representacive as described in the Tank Farn HASP

\subsubsection{Core Tean Industrial Safaty hctivities}

- Develop training for I5 programs ard site-wide issues

- Coprdjnate PlC trajming with IfTp Trasning organizaljom

- Coordinate development of 15 program implenentation stratagies

- Particidate in development/perform 15 revien of TwRS-level documents (S/R]DS, FSAR)

- Rev lew THRS-wide procedures and project decumentation

- Maintarn the Tank Farmo HASP

- Perform independent Qperatigaal Radipess feriews (ORR)

- Research/roview potential nę instrumentation/technologies 
- Astist with investigatians (e g prestigation of problem arpas ideritified by 15 (rending)

- Perform is trending

\section{4,2.4.A Field Industrial Safety Activities}

- Provide facility or characterization Project-specific Iraining an t5 prograns and is5ues

- Provide PfC tratising

- Roview maintenante and operations procedures and facility or Chorasterization Project-spec if ic project documentation

- Provide is infut to work package planiting and revier

- Perform Occupancy Resdinoss Roviows

- Participate in facility or Characterization Project-specific Operational Readinęs Repulews

- Perform Is field surveys and conslruttion site walkdowns

- As5ist with accident/incident investigations

- Participale in facility safety coumctis and the OAC

- Participate inforovide rnput for nonthly safety neetings

- Provide miscollaneous IS suppart le g providing guidance on safety issues and resolving concorns?

\subsubsection{Fire Protection Professionals}

\subsection{5.) Quslifications}

Entry level requirements far fire protection professionals include a Bachelor of Science Degree from an accredited college or university in engineering or related techrical field [f not a graduate, six years of experience in fire protection engineering wich demonstrate a working knowledge of fire protection principles and technical requirements eas be substituted Requirenents for being a fully qualified Safety Professional thelude completion of the qualification progran outlined in the safety oepartment Afarnistrative Mandal (WHE-IP-0030), SAF-] 2, Tafety Persannel Qualification Procedure "

\subsubsection{Fire Protection Rasponsibilities}

All Fire Protection \{FP\} actryities, both TWRS-unde and facility-specific, wll be perfored through the TARS Safety Core group Fire Protection responsibilities and activities include

- Revien englneered work packages, antenance work packgges, equipnent specificstions, project doc umentation, materiałs lists or other materials haring fire protection mplications 
- Raview propased changes to the functional use of buildings or structures to ensure "amproved risk" eriterid relating to conservation of life and property are mantained and upgraded

- Reriew all work control documents impacting fire protection equigent or comprents

- Provide an overview of the fire protection progran that includes 1 ife safery and equipment lesting, inspection, and maiptenance progran adequacy

- Perform fire protection as\$essmenls to meet the requirenents of Qde Order 3480 TR

- Prepare area andjor facility fire Mazards Analyses to camprehensively ussess the risk from fire within individeal fire aress in relation to existing or proposed fire protection

- Act as a Site Safety and Hedith Representative as describod in the Tank Fate HASP

- Develop traiting for fP programs and \$1te-wide $15548 s$

- Particigale in development/perform FP revigu of ThRs-level documents (FHAS, SfRIDS, FSAR)

- Perform independẹnt Operational Readingss Reyiews (dORR)

- Participate in Occupancy Readiness Reyjews

- Assist management wrth incident faccident investigations

\subsubsection{Muclear Safety Professionals}

\section{$4,2,6,1$ Qutilifications}

Entry level requirements for a nutleur safety (WS) profossional include a bachelor of science Degree from an accredited college or unryersity in engineering, chemistry, physics, or related science Requirquents for being a fully qualified Safety Professional include completion of the qualification

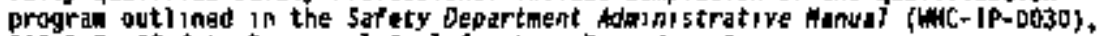
ShF-1 2, "Safety Persamel Qualification Procedure n

\subsubsection{Mucloar 5nfety Responsibulities - Eeneral}

Nucloar Safety personneT proyide expertise, as515tanç, orersight, and support for TwRS operations and activities The following are responsibilities of al1 TWAS lfuclear Ssfety professionals, regordless of their bosition in the 
organization structure Specific duties associatod with fiold and core coum nuclear safety personnel are listed separately

- Review design and plant operating procedures and related documentation for nuclear safety $15 \$$ sues, as recuilsed

- Reviaw work packages and rolatod documentation as appropriate

- Review and approye safety rebated documentation such as lnterie Safety

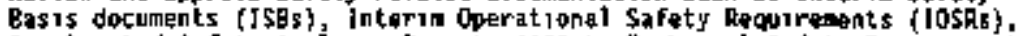
Accelerated Safety Analysis Reports (ASAs), Techn1cal Safety Reouirements (TSRs) and Safoty Assessment Reports (SARS)

- Assist waste tank facilities un maintaingng an adequately defined safoty Dasis

- Provide an independent determination of whether a proposed nut lear attivity involves an Unreviewed safety question (USp)

- Participate in operational readiness reviews and assessments to verify that the waste tank safety aspects of the facility, staff, procedures, and technical safety bases for operation are in pioce and rady for the defined operation

- Reviow operational safaty requirements (OSRs) for ieplementalion and reccemend correttive actions as needed

- Review nuclogr croticality safety and validate it is anintianed in ThRs operations

- Monitor safaty txperience to assess performance levels and trends, and propose aporopriale courses of action to improye the progran

- Verify nutlear facilities have instituted and continue to vtilize an effective prograth for U50 deternonations and analysis

- Participate in andfor provide oversight of Accident lnvestigations of events of slghificance to nuclear/criticality safety

- Invest igate and respond to nuclear safety related employee concerns

- Assist in determining or evaluating root causes of nuclear safety issues, and propose imediate and long-lerm correclive actions

- Participate in safety councils, comottees, and review coards, as required

- Perforn operations self-assessments and operational safety as\$e\$sment\$, and parkicipate in integrated audit appraisols 


\section{4,2.6.3 Core Teas Huclear Safety Activities}

- Participate on oral Certification Boards (criticality. shift managers)

- Review Twas-wide procedures and project documenlation

- Particigate ip FSAR development/rewien

- Perform operational safety Assessements

- Supgort usa process

- Participate in OSO to TSR conversion processs

- Coordinate resolution of erilicality \$afety 155 ues

- Provide representatives to conmiters relating to nuclear safety coefente Huclear Faf 17 ities Safety Baard (DAFSB), Plant Review Comm titen (PRC), Standard Reyser Comialtete, Emgineering standards Board, Hanford Personnel

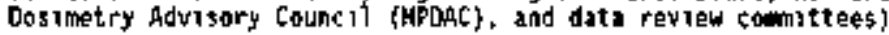

\subsubsection{Field Huclear Safety Activlties}

- Revigw ratantenanté and operating procedures and facility or Characterizalion Projecl-5pecifit project documentation

- Provide NS input to work package planting and review

- Perform post-reylews of activity documentation

- Participate in facility or Characterization Project-s,pecific Dopratianal Readiness Reriews

- Participate in Conduct of Operations 5 elf Assessments

- Parfor facility or Characterization Project-specific USO sereenrings

- Participate in QSD to ISR conuersion and maistanance

- Provide representation as requested to Pac and Iechnical Revian Group and Epard

- Proyide alscellaneous nuclear safety support fe g providong geidanse on nuclear safety issues and perforting walkdows? 
TH-13 IEFT Bi,A:AK. 


\subsection{PROBRNM IKTERFACES}

The following sections describe graups and organzations TWRS Safety interfaces with, prosides support or inforanation lo, or participatas in an a regular basis TWRS \$2foty also interacts with other organizations when neccessary for special projects Program communucation interface chains for Industrial Hyglene, Industrial Safety. Fire Protection. and Muclear 5afety Support are shawn in Attachments $3-6$

\section{S I SAFETY CENTER of EXPERT]SE [COE]}

The Safety Center of Expertise is a coard comprised of representatives from projects/teans throughout Hanford (IURS, FFIF, SHF, PUREX, Solid Waste, and Canstruction Projects\} to address site-wide safety issues Central sofety support grousps proylde expertise in Industrial Hygtene, lodustrial Safety, Nuclear safety, and Fire Protection and site-wide safety support functions Attachent 7 shows the central support groups, who report to the Safaty Director (Jinterpretive Authority for the Safely [DE)

The Safoly toe and support groups are responsible for progran and procedure deyeloperent for ragulatory comoliance within WHC, standard interpretation, maintaining safety eanugls, supporting conflitt resolution, developing sitewide training, and corordinating COE Board and safety disciplune meetings TWRS Safety assists in the development of procedures by providing input that will sapport practrcal iaplementation, rovituring dociments initially and when revised, provide day-to-day imterpretations of regurrements, integrate requirements whth planning and work teans, provide safety support and training to TuRS personnel, and provide expert guidance to the TwhS coE Representative

Some of the site safaty functions the caf support groups provide include initiat ives for safety awareness, accident statistics and invostigations, and developing safely performançe reparts They also proyide safety services \{LW. 1S, FP, MS s to those projects/facilities that of not support theis own full cose safety professional Aw'srenoss activities inclesde safaty articles in the Hanford Reach, posters, and copanumigues TWRS Safety provides information that may be of coupany-wide interest to the COE for publication, assists in and follows-up on TNFs accident investigat ions, and provides information regarding TNRS safety astiuities for performance reports

The primary intarface between TWRS Safety and the Safety COE Board is through the Thas COE Representatives The representatives attend cof Board meetings and dissemate appropriate information to TNRS Safety personnel They carry information and ideas from the field and core safaty personnel back to the COf COE support staff wark directly with TwRS Safety Dersonnel when conducting investightions, ar abtaning inpert on developwent of prograros, procedures, and publications 


\subsection{HAMFORD EMH[ROHGEMTAL HEALTH FONIMATION (HEHF)}

HEHF has bees contracted to provide wedical survelliance Pre-placement, periodic medical surveillance, and return to work or fitness for duty examnations are provided Tuns 5afety provides reccomendations to applicabie matagers for personnel to be included in a medicat survellilance progran and data regarding health hazards in the workplace to HEHF This data is based on hazards defined through assessments such as high molse, carcinogens, chemical exposure or temperature extrewes

\subsection{TMS LESSOMS-LESFHET PRGERAH}

The TWRS Project has a Lessons Learned Progran and Coordinstor to reviev incidents, actiwities and near-nis\$s that may have value to the project in improving and correcting managewent systems lessons-learted bullatins are published and distributed to the working groups for information and action. Twas safety rey rews the draft safety bullet jos as subject matter experts for accuracy, compliance information. and 1esson completeress priar to publishing. TNRS \$afety also prowndes subject information to the TiRS Project Lessonslearaed coordinator based on discoveries from reriews and ovarsight act.1vities

\subsection{DOE-RLAP}

TWRS Safety communcates and has a direct interface with the DOE-RL TNRS Prograd office The DDE Prograa 0ffice is proulded with status informalion of the Thas Safety program through wothly mettings and a quarterly raport. The quarterly reporl provides activities and 51 at us in meet ing the Work Braakdom structure (WBS) del iverables and progran implewentation The deliverables astablushed are a product of the joint effort in developing the fiscal year work plan The work plan sets the overall direction and scope of the TWRS Safety onganization The TuRs Safety Core Group acts as the interface with DOE-RL for reporting purposes. DOE-RL staff work direct1y with TwhS Safety personnel in areas such as audits, assessments, and investigations

The interface between TWRS safety and DOE-HO is through DOE-AL TWRS Safety has been used in deanstration or special projects and has been involved in DOE-HQ reylews and assistance prograns

\subsection{COUPORATE WESTIWEHOUSE}

The primary interface for commocation, inforiation and corporata suryeys with Corporate Wastinghause Environental affaits is through the Sefoty Cof. Information pert unent to implemenlation and the corporation is disserinated through this point of contact, and relayed to aperations organizations throwgh fachlity tof representatives This safety participates in corporate reviews and in surveys 


\section{DEFENSE NUCLEAR FACILTTIES SAFETY BOARD (DNFSa)}

The Daf 5 is is tharlered by Congress to review and evaluate the content and inplementation of the stasdards relating to the design, construction, operation, and decomissioning of defense nuclear facilities of the Department. of Energy The role of the board is to ensure adequate protection of pubitic and worker health and safety and the environnent at thesp facilities through site visits and assessments TwRS Safely provides information to the Board through the DalFSB Point of Contact as required, and assists in resoluing 15 sups related to tank farm safety

\subsection{STATE H:T FEDERAL RECULATORY AGEMCIES}

State and Federal regulatory agencles such as Occupatipnal Safety and Health Administration (OSHA] PTOY Ide diraction and guidelines for worker safety The Safety COE acts as the intarorative athority and interface with regulatory agencies The cot disseminates information an new or raysad regulations to facilities and makes appropriate changes to company-ride prograw manuals. Tuhs Safety 1 mplements the requirements and revisions as nocassary

\subsection{WORKER SAFETY AD HEMLTH SUP-PANEL COMITtEE (\$Ub-TAP)}

The Norker Safety and Health Sub-Panel 15 a sub-conmitteg of the High-Level Waste Tank Adyisory Pansl (TAP) The group, under contract through Battelle, FiL, 15 a group of renawnod professjonals chartered by DoE-AL to act as an advisory board on safety and health 15 sues related to the TuRs Program The c0matt of 15 responsible for reviewing and making recommendations on $15 \$$ les related to the safety and health of workers associatod with Tank farm activities, wasle handling, works ite hazards, hazard prevention and controt, risk assessaent methodology and apolication, tralning, and achiering WPP status They also provide input as neaded on now, updatod, or revised orders, regutations, and requirenents The TWRS Safety Core trowd with input fron fiald safety personnel, provides information through presentations and the Sub-TAP polat-of-contact) on curręnt safety prograns vithin TNRS, and

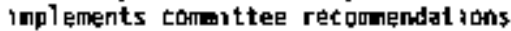

\subsection{NAIFOFП FIRE DEPARTMEMT}

The Hanford fire oepartment prowides fire suppression, eargeney nedical and abbulance services, specisl rescue support, hazardous material rosponse, fire prevention and fire systen testing and eaintenance with the proficiency to control and terminate emergency siluations that threaten the operations, enployees, or interests of the DoE-operated Hanford 57 te The fire safety prevention program includes fire protection system functional testing inspection and maintenance, self-contalned breathing apparatus maintenance, bulding tours and inspoctions, and pro-fire planning Thas Fire Protaction pergonnel proude engineering tethnical support to the Hanford fire Departoent to assist with iaplementation of the fire protection progras, fire investigations, and resolution of fire systew discrepancies 


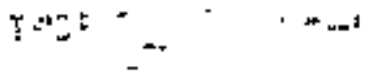




\subsection{RESOURCES}

\section{6.l EQUI PNERT RESOURCES}

Attochoent 8 contains a listing of equipment ayallable for use by TWRS Safety Dersannel, including equipment needed to perform inspections and air, noise, and light monitoring. All industrial hygiene monitoring equpanent is ouned, majntained, and çalibrated by the IH Equipment Laboratory. Howrver, anT sampling equapment used on a daly basis by the IH lecthreians 15 stored and field calobrated by the techricians. Such equipment is identified on the attachment.

\subsection{STAFFIMG}

Currently whin the TWhS Salety there are 24 exempt full-trme enployees \{FTE 5), 15 non-exempt, and 4 managers perspnnei are distributed among the field and core groups as shom in Table 6-1.

Table 6-1. Tufs Safaty Staffing

\begin{tabular}{|c|c|c|c|c|c|}
\hline & $\begin{array}{l}\text { IfFs spifty } \\
\text { \{care Groupl }\end{array}$ & $\begin{array}{l}\text { emt/ryme } 50 \\
\text { suppour }\end{array}$ & 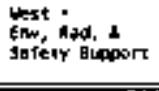 & 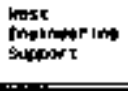 & 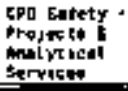 \\
\hline 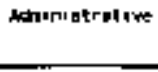 & 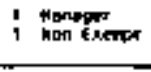 & 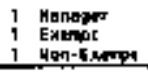 & 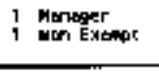 & & 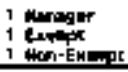 \\
\hline $\begin{array}{l}\text { Induatel } 1 \text { | } \\
\text { sefoly }\end{array}$ & 7 Intapt & 7 5xapt & J Inחpt & & $1 \mathrm{lmapt}$ \\
\hline $\begin{array}{l}\text { Fine } \\
\text { Protericturas }\end{array}$ & 2 EKmont & & & & \\
\hline $\begin{array}{l}\text { Industr bal } \\
\text { Nyaithe }\end{array}$ & 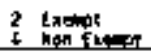 & $\begin{array}{l}1 \text { tants } \\
3\end{array}$ & 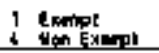 & & i lespt \\
\hline Hutlapr gutory & f Eltept & 3 Erenp! & & I Enempt & 1 Fherer \\
\hline
\end{tabular}

\subsection{BangET/MORX BAEAKDOHIN STRUCTURE (NES)}

Furiding for TNRS Safety groups is oirectly through the line arganizations. Field Safety groups are funded through operations and CPO, while the IWRS 5afety core is funded through Englneoring Det iverables and scope of work for THRs safety personnel are defined in the approved Nutt-Year frogram Plan (MYPP).

Marlagers of each prganization participate in the budget plaming process for fach fiscat year Specific budget information and tracking is the responsibility of a Budget Analyst in each line organizalion 


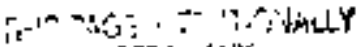

$$
\begin{aligned}
& \therefore \text { - }
\end{aligned}
$$




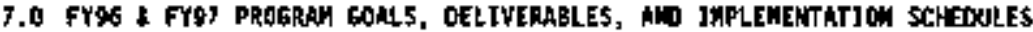

\subsection{TWRS SAFETY GOALS}

The gosls of the TWRS Safaty organization were established to protect enployees health and safety, waintain property, and safeguard the safety envelope coals were established (below), and strategles and action planning - lestones were detined for asnaging the transition and developing a path forward in excellence

- Continue to provide effectiva safety support services to ThR in Industrial Safety. Fare Protection. Industrial Hugaene, and Huclear Safety Support

- Maintain effective packaging and presentation of staff acconolishments and studies to take credit far our demonstrated excellente.

- Clearly defime and document the TWRS Sgfety Progran to include responsibilities, accountability, and processes

- Estabjish a sound Financra] Plan which supports the program and field needs to support the safety and health functions of TWRS, and is supported by each profossional

- Devel op a comalnicalion pracess to resolve difficult issues which affoct hepalts and safety

\subsection{DELIVERABLES}

Deliverables are specifically assecrated with managent of the cost actounts. astessing and assuring regulatory tompluance, analys is of the work site and hazard ideptification and control Mosl activities relate directly to 1mplementation of the Westinghouse Hanford Company Norkar Protection Program the uwbrella for the war octupational safety and health activitios. Spocific deliverabies and activitits for each group art provided in the paths formard (Soction 8 o)

\subsection{SAFETY PROGRAH IMPLEHETTATION PLAHS/SCHEOULES}

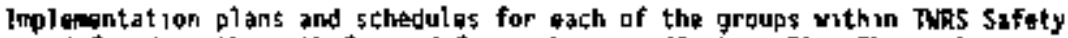
are defined in the path forward for each group (5ection B]. These vlans prorlde guidance and targit dates to meet del iverable and mlestone commitments These tasks also represent significant events in program implementation and continuing inprovenent Programatic deficiencies will be identified from foedback provided by progran audits, survelllances, salfassossments, etc These progran deficlencies will then be developed into tasks wich will be addad to the program implementation schadule. This will ensure facu5, campletion, and attention to recognized deficiencies. Marrative descriptions of various program elenents and activities being enphasized in FY95/FY97 are contained in Section 6 


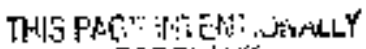

EFT TRLANḰ. 
In order to achleve the goals set forlh in Section $I$, the path forward, or melhad of athrowing those goals, wust be defined The path forward towards This Safety excelleace wil be achreved through the defustion delpuerables and milestones, schedules for completion of those itens. avallable resources (Saction 6), and clear definitions of rales and responsibslities (Section d) Jn addition, with the recent reorganization of the safety orgapization, transition issues are addressed in section 9

\section{a I PROERdH EHPHASIS}

The following are destriptions of some of the health and safety prograns and activities being emphasized during 5496 and $\mathrm{FY} 9$ ? All of the safety groups are involued in these sctivities/prograns to sone extont, whethor it is program review, training development, progran ieplementation, or field conitoring

\section{a I 1 Dactrantent Reviow}

Dorcument review is a major elewent of all THRS Safety professionals. responsibulities Doctuents are reviowed and approyed by professionals who ensure activitizes and operations will be carriod out in safe manner, ensure potentilal hazards are addressed in an appropriate manner, and nake reconondations for resolving safety lssues The following is a partial $115 \mathrm{t} i \mathrm{ng}$ of types of documents revieked by Safety profossionals horo complete listing and matrix of wo reviews them is provided in Attachment 9

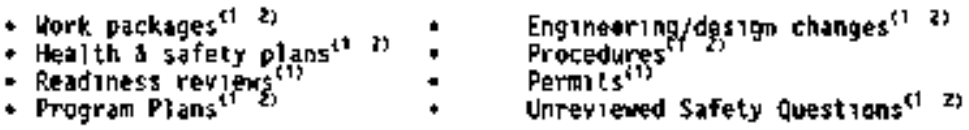

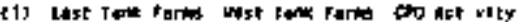

(2) Cor Golp decivity

\section{g 12 Carciongen Control Progran}

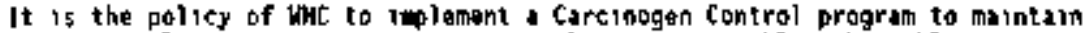
occupational exposure to careinggens as low as reasongbly achieuable Industrial Hygiemists identify, eyaluate, and effectively enșure control of all applicable carcinogens listed in 05HA 29 CFA 1910, the ACGIH TLY Mandbook, Notional Foricology Progran. and the International Agency for Research on Cancar The Cartinogen Control Program applies to operations where an industrial hygienist has determond that use of a carcinogen crestes a robsonable potantial for occupationat exposures Exposure shati be annimized by identification, eyaluation, control, periadic reyiex, and eaployed ewaluation and medical nonitoring in accordance with the fooustrif Hygent

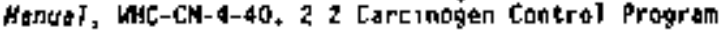




\subsubsection{Hazard Commnicution}

The Hazard Coranication Program is a developing progran within the CDE IH Support Group It has been proceduralized, mitial traing is prosant, and MSOSs are avallable for a majority of the chewlcals on-site This will be an area of focus for Fr96/FY97 to ensure consistency of implewentation within TWR 5

\subsection{4 toad Control}

The lead contral program is based on requirements of OSHA standards 29 tfFR 19101025 and 192652 Impleantation of kead control standards during FY's/fyg7 includes developing nectessary lead compliance plant, evaluat ing lead exposure potential, reviewing records and blood lead data, ensur'ing adequate persannol monitoring, and developing and conducting eagloyeg training

\section{B.1.5 Erganomics}

A program for ergonomics is in the development stage continuing worksite revlews for repetitive thotion studies are currently being schedulad through the coe th \$upport Group A reviaw of the current NHC progran will be conducted dhuring 1996, and In techncians are being trained to conduet ergonomics assessments In addition, ErgoSart softurare has been made auallable to enployees through the Hanford cocal Area Network, for use on conduct ing their awn workstation evaluations

\section{Q.1.6 Molse/thearing Conservation}

An outline of the noise/hearing conservation program was 15 sued into the

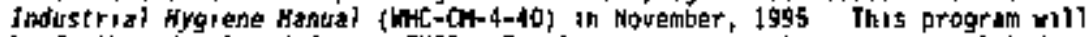
be further developed during FYg Basel int source monitoring is cospleted within THRS, and initial gudiometric testing is being performed The Hearing Conseryation Progran and Survey Procedure will be released into the fodustrid Hyglene Hanya? \{NHC-Ch-1-11\} during $\mathrm{F} Y 96$ leplement ation and further developasent of the noise/hearing conservation program woll include pergonnel monitoring and training of employes to increase amaremess of the problem

\section{1,7 Confined Space}

tonfined Space 13 a mature program used to ensure employee safety men morking in a conf ined space A new WHC Conf ined Space Procedure was deyeloped and 15sued during ty95, to be rovigwed by [ndustrial Hyglene The TWRS Copfined spaces Health and Safety Plan will also be reviewed during FYg6. 


\subsubsection{Cheaicol Hygrene P1an}

Wht Laboratories, including 2229 and HSCF have devetaped and implemented Laboratory Chenlesl Hyglene Plans in accordance with 29 CFR 19]0.1450. current progran eaphasis is in supporting the required annual review. In addition, one of the Analytical \$ervices path forrard activities for this and next fiscal year is to perform an assessment of potential chemical exposuras. Th1s assessinent will be done in accordance with the Chemical Hyglene flan Exposure Nonitoring requirements 


\section{; LEFT BLANK.}




\section{B.2 ThRS SAFETY tORE GROUP MATH FOFUARD}

Thrs section proyides the luts safety Core liroup path formard activitins to sddress key programs and lssues. Th15 psth forward 15 based upon the general inforaation provided in this Thes Safoty Prograw Plan, the current Iugs Safety mork load, and a protizization of issues that should be addressed in the near future. This section describes each TWA5 Safety activity and provides an inplementation plan/schedule for ath (Attachments 10 - Is). A150 included are Fur? Time Equaratent [FTE] estimates to better allow for plan modifications and prioritization

\section{2.] Adaind stration and dversight Activities and Oollverabies}

The following shows the planed This Safety core group adtanistration actryities and deliverables planned for the end of FY96 and FY97. Attachwont Io shows the implementation schodule for each activity.

1) Provide manageaent and auersight of the TWRS Safety tors group. (2.5 FTE\}

2) Hantain a program plan for definung the Twits safety tearh, charter, goals, and object aves, and path forward. (Contract support)

3) Provide guarterly and annual reparts on status of deliverables, -l lestones, trends of OSHA findings, performance moasures, trands, and program managewent to QDEE-AL. (D.J5 FIE)

d) Weet monthly whth DOE-RL TherS Tank bperations - (.05 FTE)

5) Develop and sutemit a Draft WPF Application for TwRS. (0.15 FTE)

6) Coordinale Safety Cof Issues as Repuirenents Representative for TWRS. (0.55 FIE)

7) Provide lechnical advisor on nuclear safely and criticality issues. (Contract Supart)

B) Perform trending on industrial health and safety survey findings, ergonomic assessment findings, employee safety cuncerns, manager safety trarning, and safety meet ung attandance. Report status qusrtarly. \{Cantract supporl\}

9) Fy96 - Support speciel projects such as the Enhanced Ugrk Planning Pilot Project.

\subsubsection{Indestrial Hyglene activities and Del trarables}

The following shows the glanned Thk5 safety core group Industrial Hytiene dictirities and delirerables planmed for the end of FY96 and FYg7. Rttachment 11 shows the roplementation schadule for eath activity. 
1) Proylde industrial hygiene progran support perfore TKRS-ride document reviews, participate in special task teans, implement new/revised standards, and implement ]H prograns [] 2 FTE)

2) Perforti IH monstoring to support TWRS 0perstions activities, inclading responding to investigations, collecting data, maintaining in equipment, field moniloring. supporting the respiratory protection program, and ar cylinder sampling (39 FTE)

3) Waintain Iank Fark Health and Safely Plan (HASP) Update as needed \{0 1 FTE $\}$

4) Perform 72 source monitoring sweeps annually and report status quarterly (0 25 FTE)

5) Develop an Industrial Hyglene Compliance Plan $\{0$ \&TE $\}$

6) Praride instructionftraining assistance to field personnel as needed (0 23 FTE)

I) Conduct 5 IH Assessments as a function of the Management Assessment Plan \{ 5 FTE\}

8) FY96 - 5upport OSA S/RIOS efforts and assessments

9) FY95 - Develop an on-going gas/rapor nonitoring plan

la) Fr95 - Condutt three (3) sets of nitrous oxide (No monitaring for tanks know to tusnate tank yapors

11) FY96 - Itplement the following prograns, report status of each at monthly DOE-RL interface meetings and in quarterly reports to management

- Exposure Assessment Program (EAP)

- Hazard Communication and Carcinogen Control Program

- Heat and Cold \$tress Progran

- Confined Space Progra.

- Hoise/Hearing Conseryation Prograd

- Asbestas/Synthetic Vitreaus Fiber Progran

- Lead control Progran

- Ergononics Program

- Man-lonizing Radialion Progran

- Bloodborne Pathogens, Sanitation, Bjohazard Program

\subsubsection{Industrial safaty Actirities and Ooliverables}

The following shows the planned Twhs safety tore graup Industrial Safety activities and deliverables planned for the end of fy96 and Frgy attechment 12 shous the implenentation schequle for each activity 
1) Provide industrial safely progran support. Perform TNR5-wide docunent reviaws, participate in special task teass/coukcils, roplement new and revised standards, implement [S prograns, and develop/provide tralning on IS is sues/toples. (0.4B FIE)

2) Develop Chapter 8 of the IWRS-FȘAR and perform is reylews of other ThRSFSAR chapters (D. DO FTE)

3) Prowide IS oversight on ICF-KH work besng performed on specific projects. (D.)向 FTE)

1) Assist management wh investigations as necessary. $\{0,1$ FTE\}

5) Astist with occupancy and operational readiness revious. (0.0) fif)

6. Conduct 6 Is assessments as a function of the Nanggement Assessuent Plan, $\{0.5$ FTE $\}$

7) Coordinate safety council activitues for TWRS Safaty

\section{g.2.4 Fire Protection activities and Delivarables}

The following shows the planned TWRS Safety care graup farf protection activities and delpurables planned for the end of FYgt and FYg?. attacherit 13 shows the implenentation schedule for each activity.

1) Provide fire protection program support. Perform TMRS-ulde document reyigws, participate in special task teams, impleagnt naw and revised s.tandards, and ieglonent FP programs, (0.7 FTE)

2) Perform and document Fire Protection Assassanents as schaduled (approximately 20 per year). (0.65 fTE)

3) Partifipate in FHd deyelopment, $\{0.65$ FTE

4) Assist with operationdloceupancy readiness reviews \{0.5 FTE\}

5) Assess classificalion of locations to National Fire Protection Association triteria, (Contract Support)

\section{B.2.5 Nuclear Safety Activities and Delivarables}

The following shows the planned TWRS Safaty core group activities and deloverables planned for FY97 and the end of FY96. Attachant lo shans the inplementation schedule for each activily.

1) Provide nuclear safety support to JWRS. Thrs racludes USQ support. particioation in review boards and comittes, resolution of criticality issues, etc. (Q.9 FIE) 
2) Participate in SSaR review and devęlopeent process (0 9 FIE)

3) Ravin TWRS-w1de work package5, ECH5, designs, procedures, and related documents for nuclear safety issues (I FTE)

4) Provide nuclear safety support to specific projects (0 75 FTE)

5) FY96 - Participate in 3 operational readiness reviews (0 2 fTE)

6) FY96 - Develop FSAR Review thecklist

3) FY95 - Conplete approxinately 8 operational safety assessmencs (OSA5)

\subsubsection{Wealth and Safety Program Enphasts}

As part of activities conducted during FY9B and planed acturitics for FY97, the TNRS Safety core group has had an emphasis on the programs below The following provide a deseription of the progran and tho current status (develophent, implemenlat ion, and forlow-up)

\subsubsection{J Vapor Monitorting}

A vipor monitaring program of the personnel exposure from tho tank farws is in progress The orogran will be basad on statistical analysis of historical data Maintẹnantę sampling will continuse, vith 72 samples scheduled to be gathered during Frg6 The purpose of the program is to assess whothar or not tank farm pergonnel are subjectad to yapor contaminants abaue the occupational exposure levels, with high risk tasks and work lacations targeted as high propity qualitative and quantitakive assessments before and duryng takk and tank content sampling and identification have increased canfidence in the rapor orogran

\section{Q.2.6.2 Temperature Extrenes}

A heat stress reduction progran was initiated within Thes for the 5 undir of 1994 and revised for 1995 lnitial review of the progra's effectiveness indicates an inçrease in employee and management awareness as whll as a reduction in heat stress illness cases A heal stress task team was fornad during the spring of 1996 to address heat stress 15 sues priar to hat weather The task tean has reported on a variety of strategies for mitigating the potential for heat stress, and their feasibility In addition to enployee training. those strategles expected to be most effective were implenented during the sumer of 1996 Reylew of the progran will be made during and after hot weather wonths ta deterimint its effectivents in reducing heat. stress, and make further inproyements to the prograt 
A cald skress reduction program was inituated during the fall and winter of 1995 to incresse employee awąreness, and potentially reduct lliness DCcurrences Jraining on symptoms of cold stress and how to recognize then is provided to workers, warw shaltars are provided, and stopping outdoor mork when temperatures reath $-25^{\circ} \mathrm{F}$ are several elements of the $t$ ald 5 tres 5 program. Folkow-up will continue duryng the fall and winter of Fig?.

\subsubsection{Trending}

Tranding defines areas to highlight in safoty awareness activities, audies, surveys, and self-assessments, and assists in providing focus to the Thifs 5afoty Program. Thas process cen quantify progra symptomatic weaknesses to help define root causes and identify safzty angagment systen deficiencles. Trending by the Twhs safety core group 15 currently being conductod on

- Industrial health and safety survey findings far East and lest Areas,

- Ergonomic assessnent findings for East and Hest Areas Tạnk farms;

- Employee safety concerns For al1 of Tias;

- Safety weet ing altendance for TuRS (by organization); and

- Complation of Manager's Safety Training by TWRS Management.

\subsubsection{Tank Farm Heaith ond Safety Plan (HASP)}

h HA5P was developed to provide requarewents and general guidel ines to minimize health and safety risk to the warkers and other personnef at the Tank Farins (WHT-50-4N-HSP-002, Tank Farn Heatth and Safety Piand Through the ust of assassments such as the CBłA, the HASP w1l be revised to reflect current informatron and controls

\section{Q.2.6.5 Mon-lonizing Kadiation Progras}

Th1s program is currently in the development stages. Reylew of data of nonionizing radiation and electro-magnetic fields and assessment df potential hazards from these fields with be performed during Flg.

\section{Q.2.6.6 Bloodborne Pathogens, Sanitation, Blohazerd}

The COE IH Support Group wll be 15\$uing a Blaodborne Pathogęn Program Plan durjing fYgs Tuts safety will revitu the plan, and assist in the implewentation daring the initial stages of the progran, including training. inyestigation of employee concerns, and an evaluation.

\section{B.2.6.7 Asbestos/Synthatic Vitreous Fibers (SVF) Progrä}

Th15 15 a mature program for working around and controlling asbestas and swf in the vorkplace. It is out 1 ined in the Industrial Hygiene Hanud, Wh-CH-410. Section 2, "chencical Hazards." FY95 aclivities include teview of new program documents and assessment of IWRS inglequentation of the program. 


\subsection{CHARACTERIZATION OPERATLON5 (ShHPLIHG) PATH FORUARO}

This section pravides the Characterization Operations (Sampling) path forward activities. This poth forward is based upon the general information prorided in this IHRS Safety Progran Plan, the current Characterization Operations work load, and a prtoritization of issues that should be addressed in the near future. The Jab]es 0-1 and 0-2 proydde objectives and activilies associated with two main goals for the group: 1) Pro-actively establish compl tance wth 29 CFR 1910 and 29 CFR 1926 to pragram characterization personnel, and achieve excellente in our hedleh and safety brograms, and 2) Lower the injuryftilness rate of characterization operations to no greater than the sile gofl of $0.85 / 200 k$ hours worked, Due dates and actiones for each 1 tem sro yet to be dẹteridinęd. 


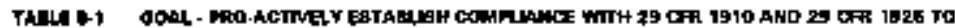

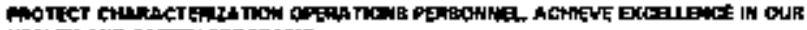

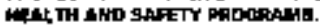

\begin{tabular}{|c|c|c|c|}
\hline Cipermer & Activinint. & 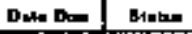 & Actimana|ur \\
\hline 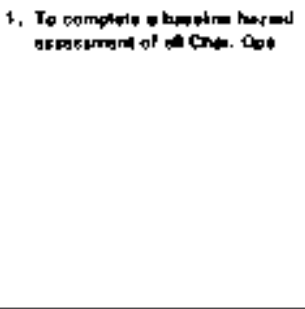 & 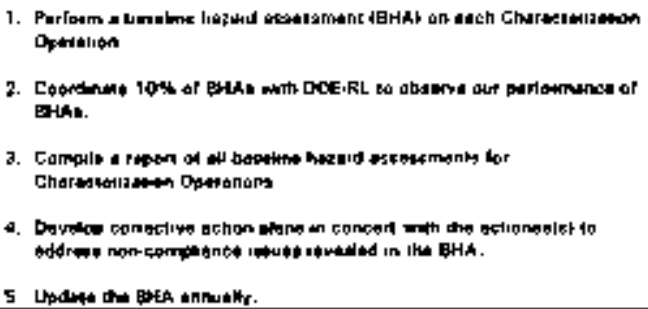 & & \\
\hline 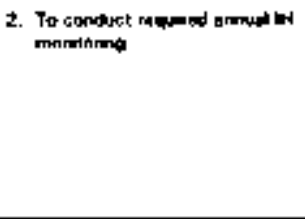 & 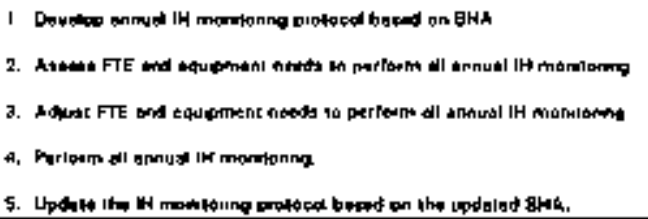 & & \\
\hline 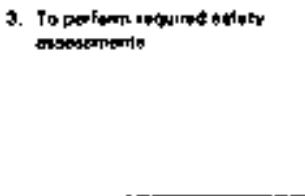 & 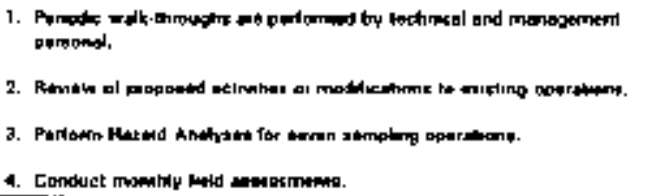 & & \\
\hline
\end{tabular}


TADLE \& 1 tCo-

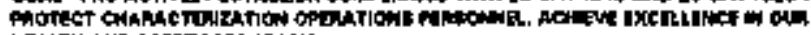

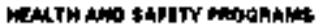

\begin{tabular}{|c|c|c|c|c|}
\hline Cosectiven & Mremitant & Den Oun & Inim & 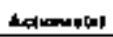 \\
\hline 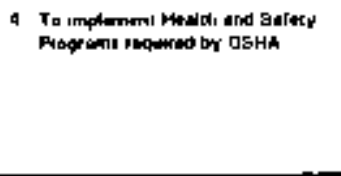 & 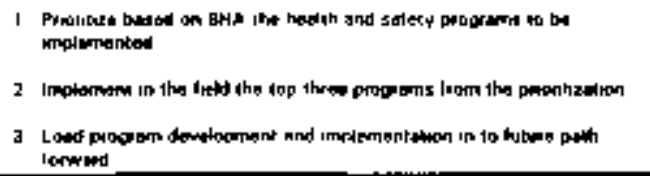 & & & \\
\hline 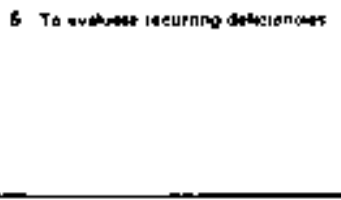 & 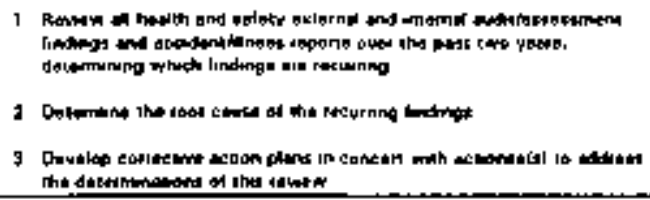 & & & \\
\hline 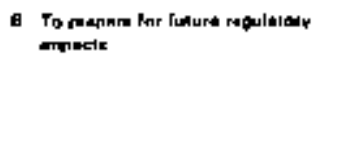 & 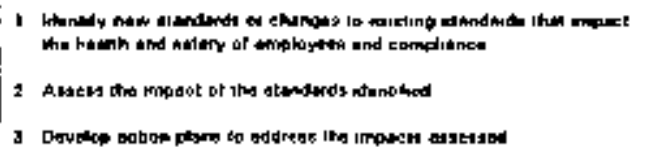 & & & \\
\hline
\end{tabular}




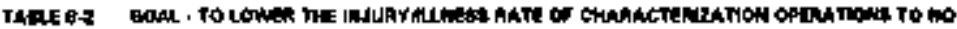

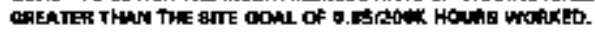

\begin{tabular}{|c|c|c|c|c|}
\hline 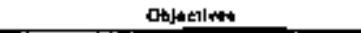 & Ammalest & Daw bua & Brabut & Ranlontaris] \\
\hline 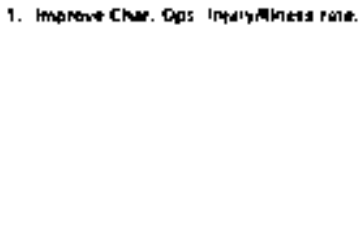 & 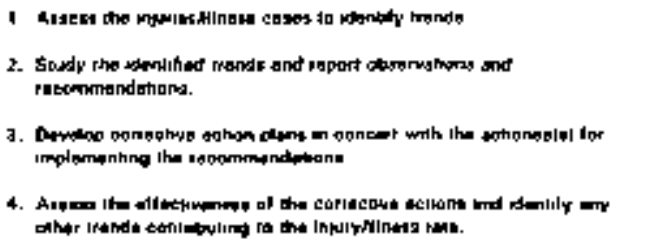 & & & \\
\hline 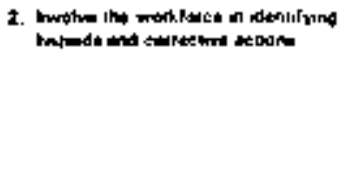 & 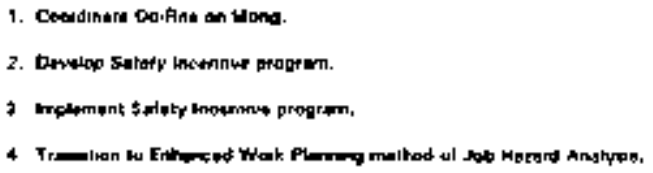 & & & \\
\hline 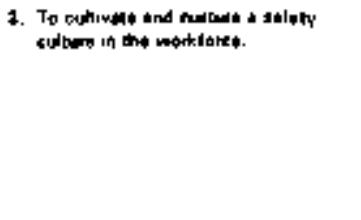 & 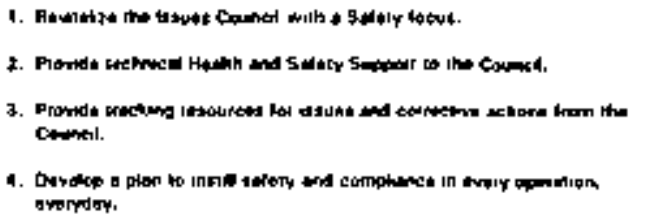 & & & \\
\hline
\end{tabular}




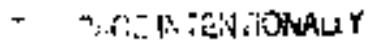
LEI ESANK 


\subsection{NHALVTICAL SERVICES SAFETY PATH FORUARD}

This section provides the Analytical Services Safety path forward activitias to address key programs and issues. This path forward is based upon the general inforeation provided in this IWRS safety Prograw Plon, the current analyt 1ta] Services Safety work load, and a prioritization of issues that showld be addressed in the near future. There are seven actions identified in the Analytical Services Safety path forward. This section describes each action and provides an inplementation plan/schedule for each. Al so included are Full Trme Equivalent (FTE) estinates to better allow for plan adifications and prioritization.

\section{4+1 Funding and Current Worklond}

The funding for analytital Services Safety personnel comes fron Anzlytical Services. A5 a result, direct support of Analylleal Serrices rill contipue to be the first prtority. In is section defines the major elenents of the current workload and estimates the FTEs turrently used. Most of this curront workload is not expected to change.

Analytieal Services Safety is responstble for 2225, WSCF, and 5AS. This support is cutrently funded for 2.Z FTEs. This int ludes I fTE Industrial Hyglene, I fTE Industrial Safety, and 0.2 fTE for additional support. The current wark load is estiested in Table 3-3. The projected basel ine morkload/schedule is provided in attactent 15. Th1s projected basel fime assumas that the Reduce Safety Papermork Review path forkard actiyity 15 successfully inphemented, rosulting in approximately 0.3 fTe available for path forward activities (Section 8.3.2\}). 
Table 8-3. Analytica] Services Safoty current Morkload

\begin{tabular}{|c|c|c|}
\hline Current Warklasd & Activities Included & $\begin{array}{l}\text { Current Estieated } \\
\text { FTEs } \\
\text { (Z.2 FTEs } \\
\text { Avallable) } \\
\end{array}$ \\
\hline Paperwork Reviews & $\begin{array}{l}\text { Docuent reviews including } \\
\text { "S" documents, JcSs, and } \\
\text { procurenopt, associatiod } \\
\text { personnel contacks and site } \\
\text { visits }\end{array}$ & 1,2 \\
\hline $\begin{array}{l}\text { Line Nanagement } \\
\text { Reques ted Support }\end{array}$ & $\begin{array}{l}\text { Commintee support, informal } \\
\text { field reviews, conf ined space } \\
\text { monitoring, elloloyee } \\
\text { concerns, ine managenent } \\
\text { requested projectg, accident } \\
\text { injury investigations, and } \\
\text { p) an of the day work reulews }\end{array}$ & 0.5 \\
\hline $\begin{array}{l}\text { Required Program } \\
\text { Revews }\end{array}$ & $\begin{array}{l}\text { Confined space, chemical } \\
\text { hygreng plan }\end{array}$ & 0.1 \\
\hline $\begin{array}{l}\text { Staff Meetings } \\
\text { JTtaining/Reports }\end{array}$ & $\begin{array}{l}\text { Safety staff neetings, all } \\
\text { Hanford training, and weekly, } \\
\text { monthly, guarterly reperts }\end{array}$ & 0.2 \\
\hline Aladit Support & $\begin{array}{l}\text { Respond to audits, appralsals } \\
\text { s survelllinces }\end{array}$ & 0.1 \\
\hline $\begin{array}{l}\text { Muclear Safety and Fir } \\
\text { Protection Requested } \\
\text { Support }\end{array}$ & $\begin{array}{l}\text { Additional document reviou } \\
\text { and on site support as } \\
\text { requested }\end{array}$ & 0.2 \\
\hline Total & & 2.3 \\
\hline
\end{tabular}

As tan be segn frow the table, reulowing paperwork regulures the largest anount of resources The total est imated workload is greater than the 2.2 FTE funded, causing sone activities 10 be deferred.

\subsubsection{Fath Forkard Activities}

This section describes each of the Analytical Services path forward activities and proyides an imlemenlation plan and schedule. At tachment 16 provides the schedules for each ectivity, including FTEs. Attachment 17 provides a strlomary of all FTE information. 
The seven Analytical Services path farward actavities currently scheduled are
1) Reduce Safety Paperwork Reyiens
2) Support Ergonamic Evaluations for Non-office Situations
3) Suppert the Lock \& Tag Pilot Program
4) Eqaluate Recurring Deficiancies
5) Perform AS Facility Baseline Evaluations
5) Establish IH Honitoring Protocols
7) Implement the Hex Hazard Communication 5tandard

\section{Q.4,2.I Meduce Safaty Paperwork Rorlaws}

Reducing paperwork revous is the key Analytical Serwices path forrard activity for 1995 currently over half of the arailable ftes for Analytical serrices safety is spent reviewing paperwork and the associaled comanicatians and site visits supporting these reviews In evaluating the other current achivities, it is apoarent that there is little rocu elsewhere to makB additional time avalable to support path forward octivities if this activity 15 successful, it 15 estimaled that 0 fTE may be avalable for wher path formard activilies

Helhods that will be eqaluated and impletuented as appropryate include finalizing a atrix ta felp engineers and docuent control personnel properly screen docutents to determine the need for safety roviek in accordance with $W H-C M-7-5$ criteria, training appropriale personnel, and evaluating procurement requirements to determint the acceptability for bilanket buthorizations for certain store stock 1 tems

\subsubsection{Support Ergonoeic Eyaluations for Hon-offico Situations}

Analytical Services has had a hogher than normal ergondalcs ręlated injury rate Many of these injuries are dus to boving heavy manowiators and other equipment. The HEAF is curreatly evaluating ard leading the health and sofety aspects of this activity Analytical Seryices Safecy will conlinue to support this effort

\section{9 z.3 Support the Lock S Tag P1lot Progrtion}

Analytucal Seruces has been tasked with plloting a new Lock \& Tag Program Line management is primarily responsible for this prograb The path forward For safoly support will likely include assisting line marigement in eyaluating the ability of $k 5$ oersonnel to implement the polot progran, eyaluating and ensuring compliante wh OSHA requiremenls. and haking conparisons with existing regulations

\section{4,2.4 Evoluate Reclurring Defiç!encies}

Based on recent audit results, audit findings in some areas appear to be carrected but the general progran and working phlotophles way nat be 
changing, resulting in recurring deficiencies. This path forward sctivity will review all health and safety audit findings in the last two years. determine which findings are recurring, determine if the recurring findings are a result of programatse fallure, and recomend thanges. Two prograns largeled for evalustion are electricsl and compressed gas storage.

\subsubsection{Porfon Facility Basel 1ne Evalustians}

A comprehensive fachity baseline evaluation is needed for all aS facilitias to better determine future path forward activities and assist in determining additional codustrial hygiene monitoring activities. The path forward far thrs activity includes deteriling the torrect protocol and inspection schedule, performing tho ovslustions, and determining the future activities. The goal of the baseline acturities will be to identify major areas of compliante and nan compliance to support additional avaluations and recomementions.

\subsubsection{Establish Industrial Hygione Monitoring Frotocols}

There is currently no progran ayalable that evaluates all laboratory themicals to determine and focuent personnel exposure monitoring

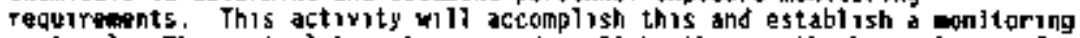
protocol. The initial target compounds will be those with chemical specific OSHA Standards \{a.k,a. "Yertical standards") All coropounds with established 0SHA Permissible Exposure Lioits will eqentually be evaluated. Apl chemicals wll likely be placed in one of three categories, those that have objective data indicating exposure greater than ituls is not feasible under current conditions, those that have histarical monitoring indicating acceptable exposura compared to 11 mits, those that require personnel exposure woticoring. Chemiçals with no exposure irets will also be evaluated.

\subsubsection{7 [mplement the new Hazard Cognmication 5tandard}

There is a new Hazard Comeunication Standard dee out in CYg?. This actiricy is currently deferred to future years due to lack of avaliable FIE. 


\subsection{WEST AREA SAFETY SUPPORT PATH FDRWAPG}

This sectron proudes the Hest Area Safely 5upport path forward activitias. This palh forward is based upon the goneral unformetion providad in this Thes Safety Progran P1ąn, the furrent West Area work load, and a prioritization of issues that should be addressed in the near future. The following table provides actuvities associated with each of the programatic focus areas, target dates, and personnel inqolued.

TABLE \&-4 Nest Area Safety Path Forvard Activities

\begin{tabular}{|c|c|c|}
\hline 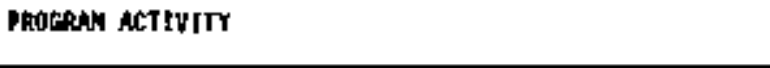 & $\begin{array}{l}\text { Thliakt } \\
\text { DATE }\end{array}$ & MCT tônEE \\
\hline 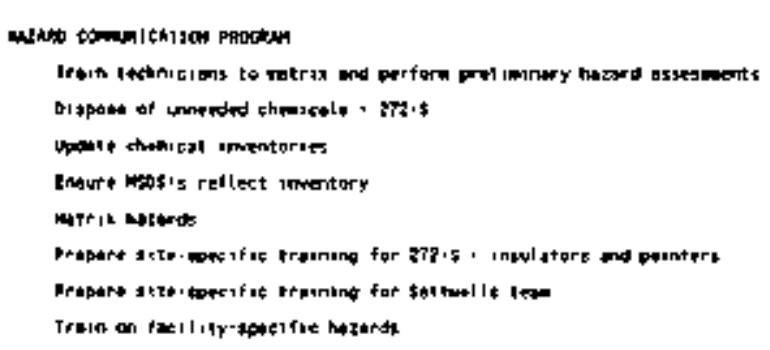 & 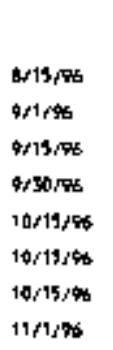 & 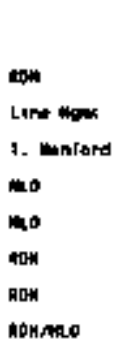 \\
\hline 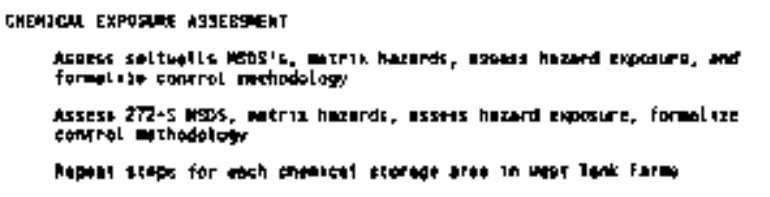 & $\begin{array}{l}12 / 1 / 06 \\
12 / 1 / 266 \\
9+0 / 96\end{array}$ & mingo \\
\hline 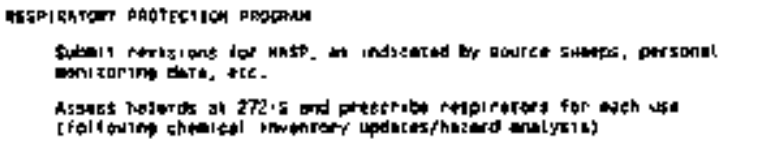 & 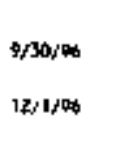 & $m$ \\
\hline 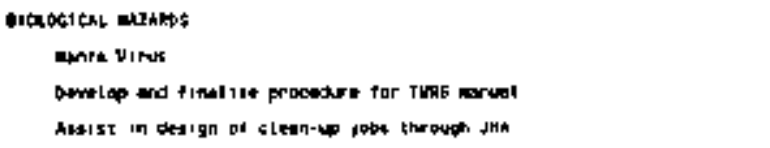 & 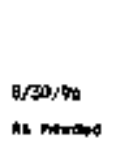 & 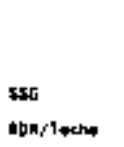 \\
\hline
\end{tabular}


IABLE 6-4 Nest Are⿴ Safety Path Fomard Act ivities

\begin{tabular}{|c|c|c|}
\hline PRDA,UM AGTIY]TY & $\begin{array}{l}\text { TAREET } \\
\text { OATE }\end{array}$ & ACTJONEE \\
\hline 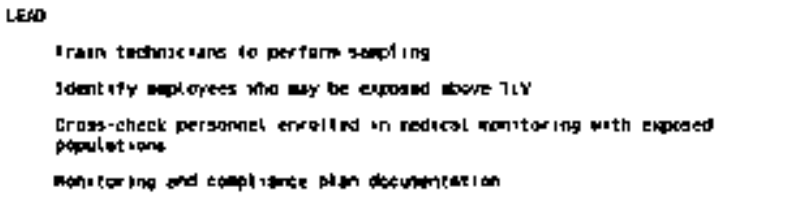 & 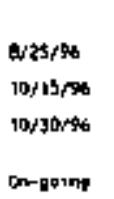 & 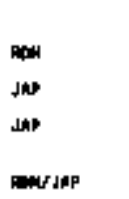 \\
\hline 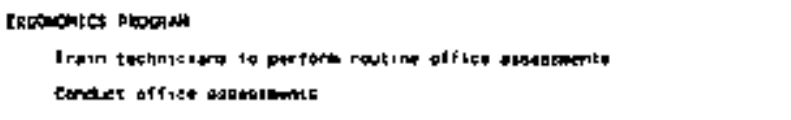 & $\begin{array}{l}\text { \$rish } \\
\text { 由. ntorthd }\end{array}$ & $\begin{array}{l}\text { SOM } \\
\text { Don }\end{array}$ \\
\hline 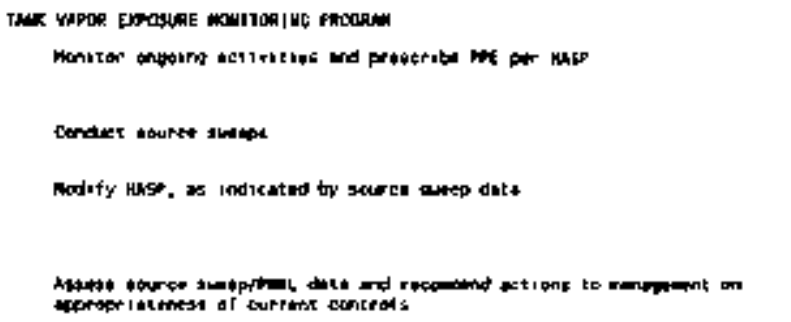 & 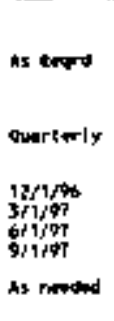 & 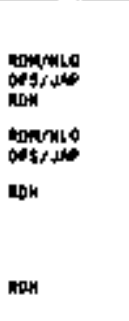 \\
\hline 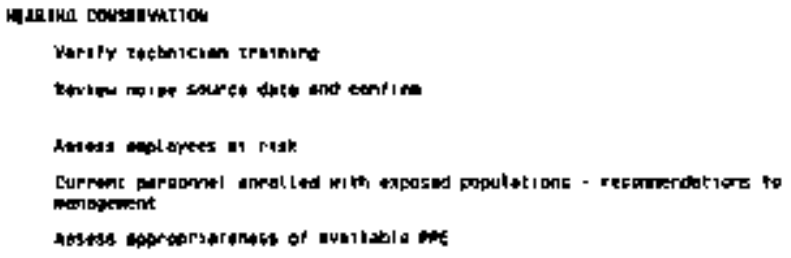 & 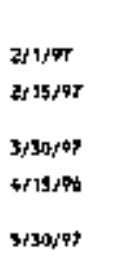 & 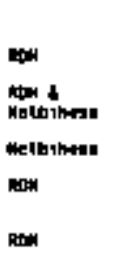 \\
\hline 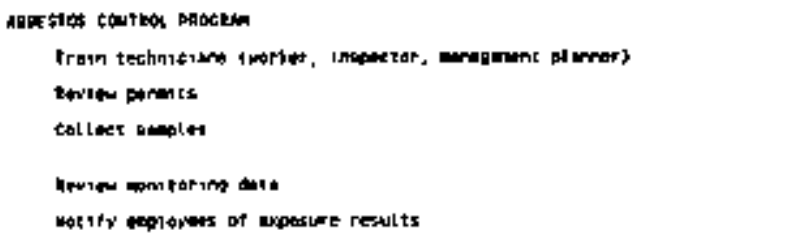 & 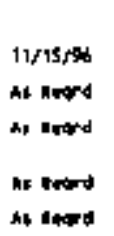 & 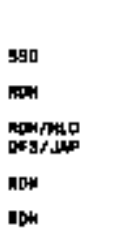 \\
\hline
\end{tabular}


TARLE 8-A Veșt Area Şafety Path Forward Activitios

\begin{tabular}{|c|c|c|}
\hline PROARA ACTIYITY & $\begin{array}{l}\text { TAREET } \\
\text { OATE }\end{array}$ & METIOHEE \\
\hline 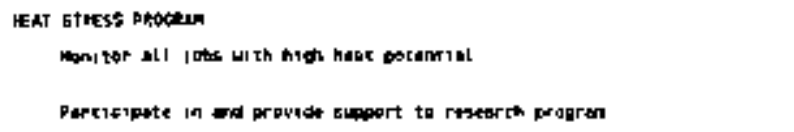 & $\begin{array}{l}\text { 1wk } \\
\text { orriyen } \\
0 / 30 r 97\end{array}$ & 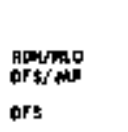 \\
\hline 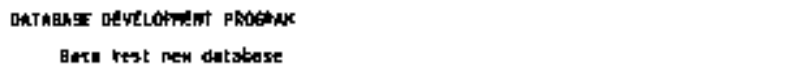 & 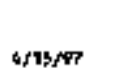 & and \\
\hline 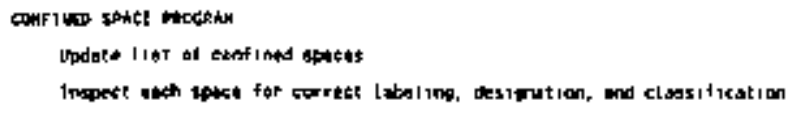 & $\begin{array}{l}12 / 15,47 \\
3 / 19 / 47\end{array}$ & 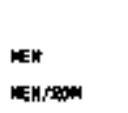 \\
\hline 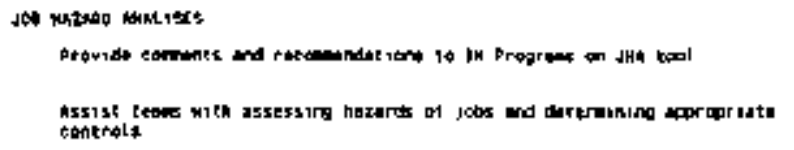 & $\begin{array}{l}\text { Dr14st7 } \\
\text { he tropts }\end{array}$ & 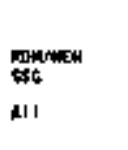 \\
\hline 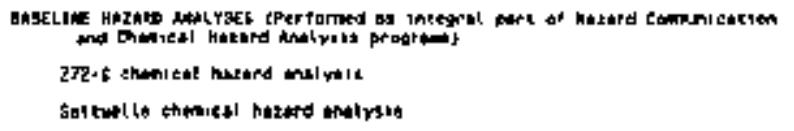 & & \\
\hline 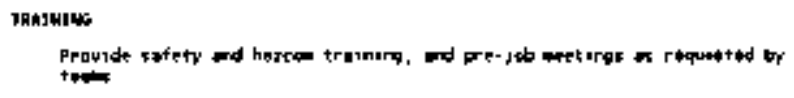 & As मeqred & PWTHEN \\
\hline 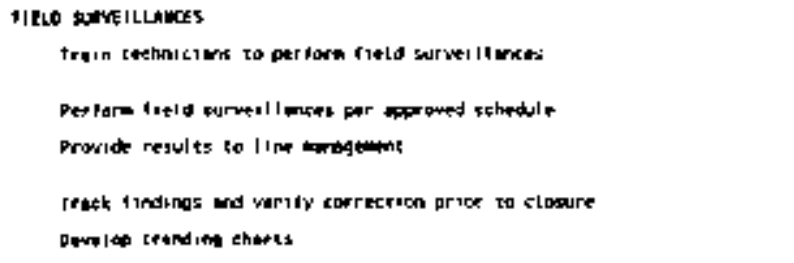 & $\begin{array}{l}\text { ari-guing } \\
\text { monthly } \\
\text { h5 } \\
\text { conplated } \\
\text { As raveded } \\
\text { Ouerterly }\end{array}$ & 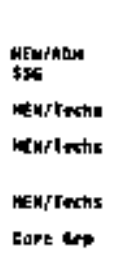 \\
\hline
\end{tabular}


TABLE B-4 Hest Area Safęty Pạkh Forward Activities

\begin{tabular}{|c|c|c|}
\hline 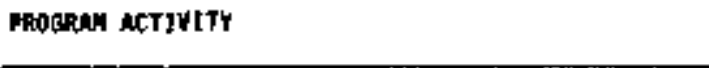 & $\begin{array}{l}\text { TABEET } \\
\text { DATE }\end{array}$ & ACTIOHE \\
\hline 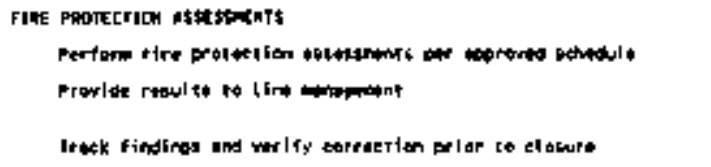 & 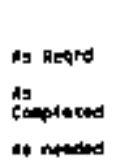 & $\begin{array}{l}\text { Ehn } \\
\text { Rann } \\
\text { Enn }\end{array}$ \\
\hline 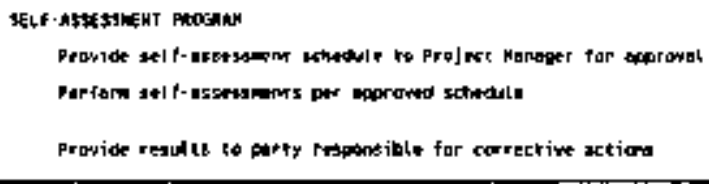 & $\begin{array}{l}\text { ounteriy } \\
\text { wominly } \\
\text { wonthly }\end{array}$ & 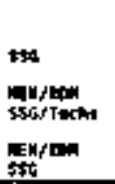 \\
\hline
\end{tabular}




\subsection{EAST AREN/EYAPORATOR 5NFETY SUPPORT PATH FOGWARD}

To Be Oetermined 


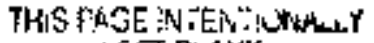
LEFT BLANK. 


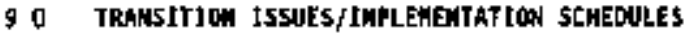

In order ta make the transition under the reorganizatiok essier, a transition plan for ach of the followng 155 ues has been dereloped or will be core fully addressed for those areas that are still being developed, a transition plan witl describe how each activity will be carried out, and how changes to the current way of business wil be carried out The plans will also contain a schedule for implewenting those changes

\subsection{COMnNICHTJUNS PLAN}

Hantalaing comanications will be critical to ensuring consistent and effective safety progran within TwkS The following are some methods that will be used to ensure adequate information exchange between disciplines and ThRs Safety as a whole

- The centralized Safety library resources will remain within the Core Gradp, but made aqailable to all safety personnel

- The quarterly report to Dof-RL will be writien by the core group, with input from field and CPO safety personnel

- Urgent inforation will be exchanged by phone and ce ail ct mall distribution lists will be devalopad for each safety discipline to ensure all personnel are notified of apprapriate anformation

- Thins safety personnel wathin each discipline (IiS. [5, JH) should malntain communication linkages to foster information exchange

- Centriz] Safety Groud (lianford-widel nonthly discipl ine meetings should be atcended by representatiyes froe each organization (field, core, and cPO)

- The monthiy 00E-RL interface metring will be organized and facilitated through the care group, with input frod the field and cporganizations on fac lity-specific activities

- Field safety personnel should attend/participate in monthly facility safety mettings to ensure appropriate safety information is disseminated to enployes

- Safoty parsonnel should attend site-wide foruns fa g, Hanfard occupational Safety and Health forun' to remain involved in the development of site-ride strategies and communicate needs from a field perspective

- COE information should be conveyed to the facility and field personnel through the COE Representatives for TuRs

- The tirs safety core group shall continue to be the min interface of the vorker Safety and Health Sab-iAp visits with participation frod field staff as approprlate

- Fow diagrams for information exchange vilb the COE, external agencies, and wrthin TrRs Safety are shom in Rttachments $18-20$

\subsection{TKAIHTHG}

\subsection{J Re-0rganization or iențatsoth}

Handgers, Team Leaders, Planners, ettc, need to remain informed of the changes taking place in the IWRS Safely structure This orientation should include 
changes in strueture, changes in warkstope, hơw business will be conducted, and haw the changes wil affect them and work in the fiold

\subsection{2 stoff Quplification}

TuRS Safety (Nuclear Safety. Industrial Safety, and Industrial Hygiene) staff nust warntain training and qualifications to perform their assigned function. Those training and qudjufication reoulrements are specified in WHC-IP-DS42 and MHC-]P-0030 Gualification and training folders for as\$igned individuals whll be transferred to line managenent for malntenance

An lnotutrial Hyglene Tecantelan Training Program has beẹn developed and is being inplewęnted at this time The progran is a result of RL findings that no forealized process existed to quatify technicians for performance of mork This program will be utilized to satisfy both core team and field IH technielan seeds The oragran will be overseen by the Core group

\section{Q.3 PRDNECT OMERSHIP}

Due to stbject matter expertise on spacific projects, a transition time will be required Short tern projects (expected completion in J - 2 months) will rombin with the current project owmer Long term projects shauld be transferred to the appropriate group (core or field) depending on the nature of the project The project transfer 15 expected 10 take several wonths, in order for the new project owner to gain the level of knowledge needed to properly ateinister the project

\section{T.1 RECOLDS MAHLGERETT}

\subsubsection{Document Revien}

Courdination of records eanagement will be essential for the re-organization to be effective Facility-specific docutents (T'siowed by field safety personnel) will be tracked by the facility document review coordinator The coardinator 111 coordinate docusents that need further revlew by other organizations A flow diagran showing the docunent review process is provided in At tachment 2]

\subsubsection{Survey Reports}

Trending is currently being perfored on office ergonowics findings and Is field and construction site surveys The This Safety Core group wil contibue this function under the new structure, and will recelve capies of survey reports from the saryeyors 


\section{$9 \$ 3$ Industrial Nygiene Monitoring Data}

Industrial hyglene monitariag data (personne) monitoring, alr sampling, source monitoringh is currently reylewed by an industrial hyglemist and entered into a database $A$ plan needs to be developed on wo will be entering infonation into the database, and how information can be retrioved when needed Who stores ar where original records are stored, and wo 15 responsible for notifying personnel of montoring results should also be defined

\section{I UKCK-UP RESOUACES}

A reciprocel program for sharing of resources is essenlial Instances $y$ ill accur where the field or core safety resources are insufficient lo address a specific need or proble. These instances could include staff yacations. trajning, unplanned absentes, or new work scope To inguire about back-up resources, a request should be made to tore or field group management. whichever is appropriate This request will be reviewed agarist current projects and proprities, and a decision adde as to the level of support that can be provided To the extent possible, every effort will be made to support these activities

\section{NORXSCOPE PAIORJTIES}

Priority and a redefined schedule of warkscope needs to be adjusted Due to reorganization, program implawintation tine frames and priarilies need to be reestablished for Characterizalion Project Operations (CPO), East and West jobs, and for cornlilance projects such as baselining efforts This transition item is addressed as detals on workstope and priarities are established

\section{OVERTIRE - IMUUSTRIAL, HYGIENE TECHIICIANS}

The resource pool for overtine will consist of all industrial hyglene tecbucrans in both the core and field organizations The pool mili be wataged by the core group First chocce of avert Ime will be given to the technician who (1) signed up on the overtime list for consideration no later than the first rorking day of edch mek, and (2) has worked the fewest total averlime hours compored to others on the list If the technician neet ing those eriteris chooses not to wark the overtime, then it will be offered to the next person on the list with the fowest arertime hours, and so on unt 11 the overtime is coyered

All oyertine requesled by the core group and CPO will be relayed to the field IH Technicians if there are any on the list Conversely, a field representative must contact the tore group as soon as overtine is requested so the process of obtaning couerage can begin 


\subsection{ON CALL LIST - MHDUSTRJAL HYGIEKE}

An on call list will be mantalned by the core group and cont inue as it curiently exists with changes to represent the new arganization. Esch InT wll be on sall for one weak at at $t$ me by sonlorlty. Our1ng the week, the IHI's warking backshift will be the primary responders. Ca weekends and holldays, the [HT on the call list will be the primary responder. For In assistance, the IHT on sall should contact the Industrial Hrgienist for the specific area

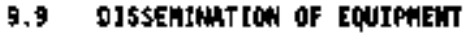

Disposable resources such as tygon tubing, sampling modis, and test equipment 11 be ayalable for use by ali IM technicions. Honitoring equipment w11) continue to be enrolled, calibrated, and supported by the IH Equipnent Laboratory located in zjola, $200 \mathrm{E}$.

\subsection{ODOR HOTLINE}

The Odor Hotline progran should be redefined to make the Operatigns \$\$ ıft Hanager the coordinator of tank yapor is 5 wes. 


\subsection{PROGRAM PALIORITIES}

Prioritization of the Thes Safety Section Program elenents is based on the priegry goals of proyiding worker protection fren rocognized hazards, meeting corm tments and establishing credibility and responsiveness to all TWAS Safaty cestomers, and providing definition to the safety progran so technical excellence and cantimuous improyement can bo recagnizad. Brogram priorices include the following:

1) Comoment to Deluverables / Goals

2) Hazard A5sossonent

3) Recordkeeping

4 Spectal Projects

5) Hazard Prewention and control

6) Field Surveys, Appraisals

7) Trending 


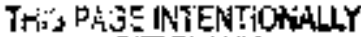

LEIT BLANK 


\subsection{REFERENCES}

10 CFR 630 120, Nuclear Safoty Munagoment

29 CfR 1910, occupationsi safety asd Heal th standards for Generai Indugtry

29 CFR 1926, Occupational Safety and Heatth 5tandards for censtruction

DAE Order 5460 5, sefety of Muelear Fecilities

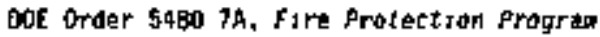

DOE Order SABO I0A, Contractor Industrial Myguene Pregrad

Dot Ordar 5ago 23, Neciear Safoty Andysss Reports

D0E order 54a3 IR, Industrial Safety Prograd for Govervment Orned - Contractor Operated facilities

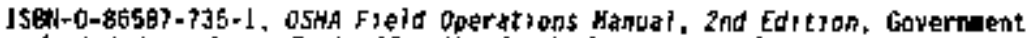
Institutes, Inc, Reckville, Maryland, October, 198?

WHC-GM-1, West Inghouse Manford Company Polic1es and Charters, "Enriroment, Safaty, and Hoalth Polyey"

WHC-CM-1-10, Indertrial Safety Masual

Wh- $[$ M-1-1], Industrial Hygrene Manual

Wha-CH-1-4D, finderstrial Hygreme Manual

wHC- $(M-1-41$, fire Protectron Nanual

WHC-CM-3-5, Docuwent Control and Record Management Wanual

WHC-CH-1-29, Notiear Critreatity Safety Manua?

NHC-CM-4-46, Safety Analysis Manuat

WHC-IP-0030, Safety Departaent Adrurastratuve Manua i

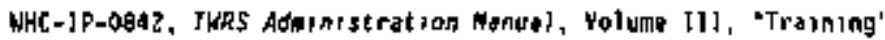

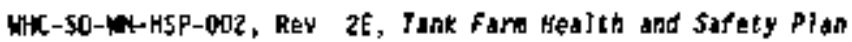

WHC-50-WH-MAR-000, ReY O. Tank haste Remedration 5ystem Wigsion Andiysis

Nigh Level waste storage Ianks/242-A Eveporator S/RJO, February 1996

Nulti-Year Progren plan 


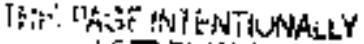 LEFT BDANK}




\section{TWRS SAFETY PROGRAM PLAN WHC-SP-1185}

ATTACHMENTS 


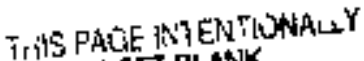

IEFT BLANK 


\section{Tank Waste Remediation System}

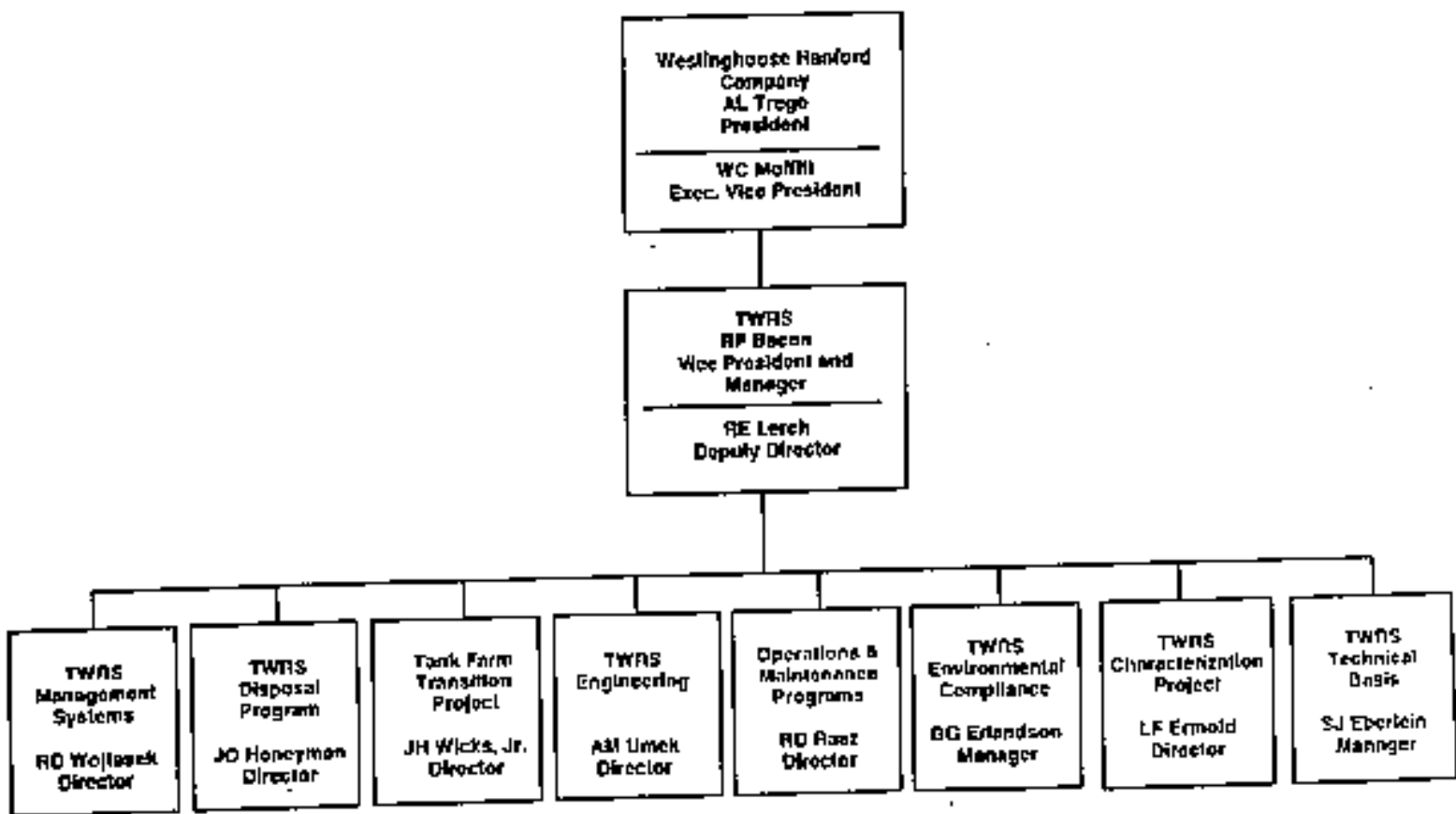




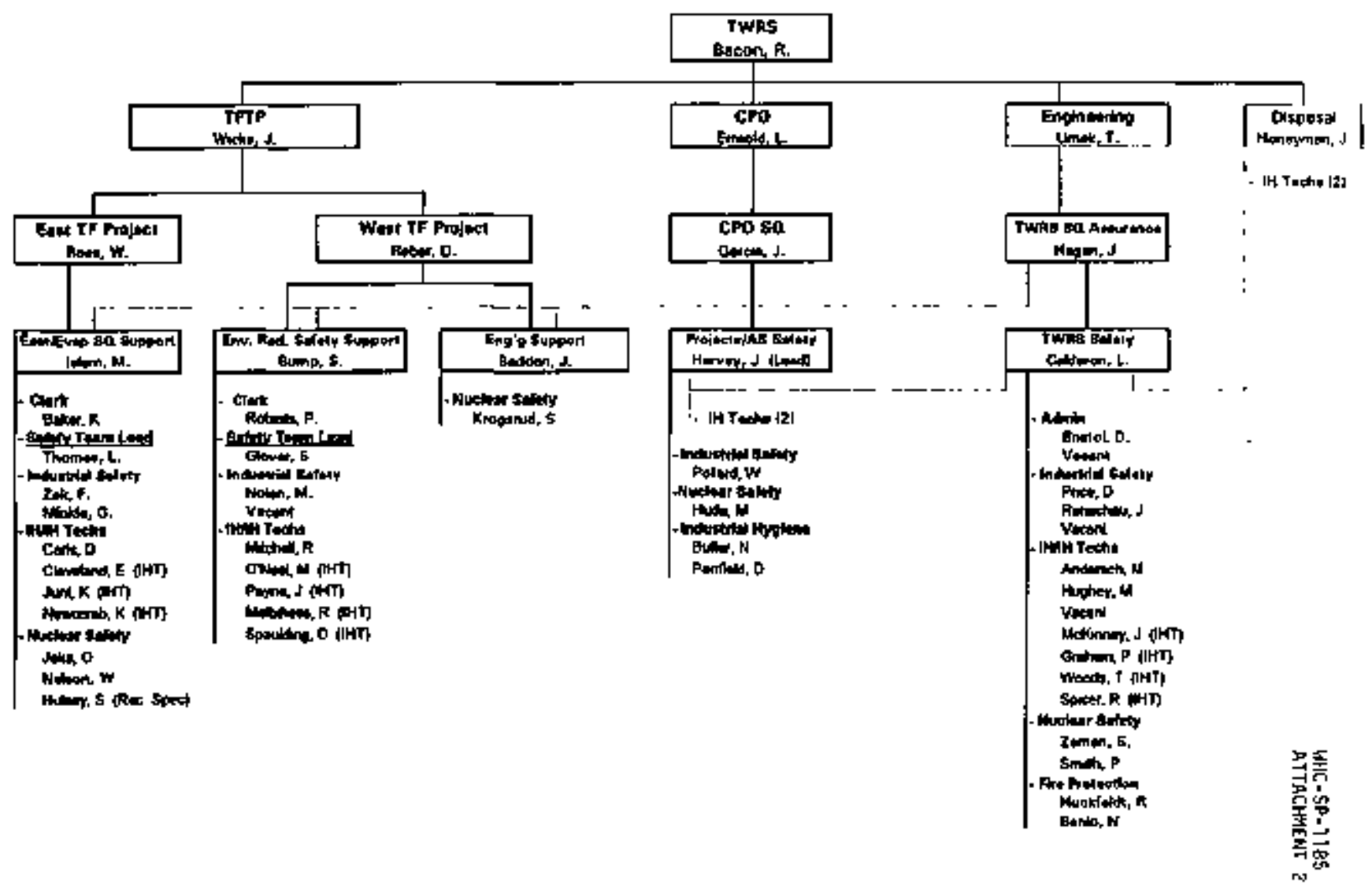


INDUSTRIAL HYGIENE

\section{TWRS Communication intertace}

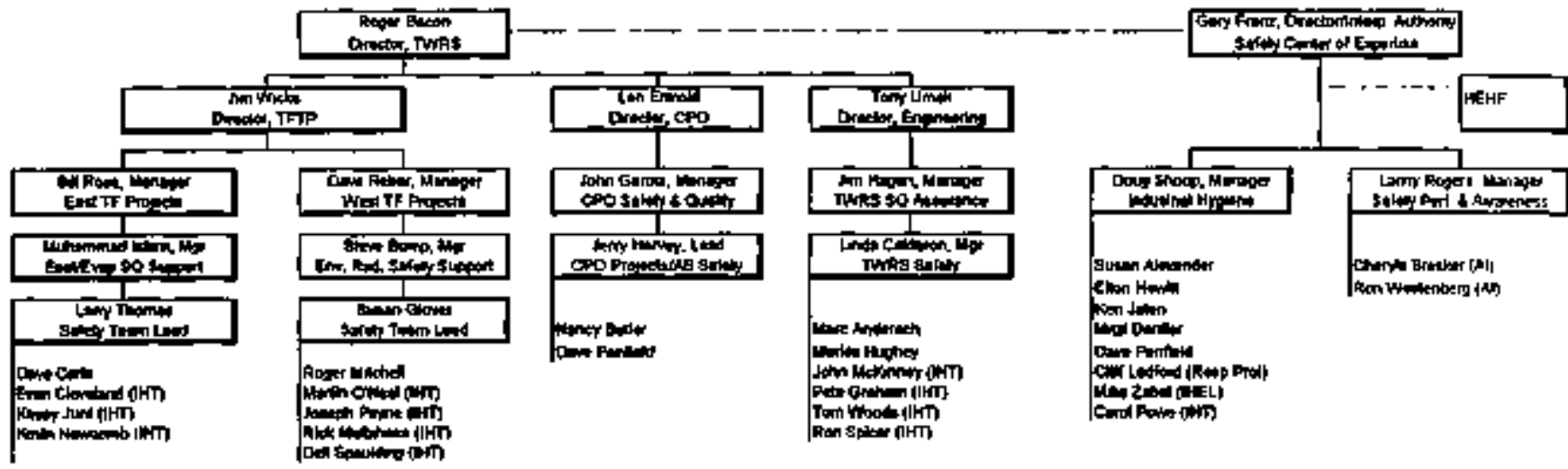

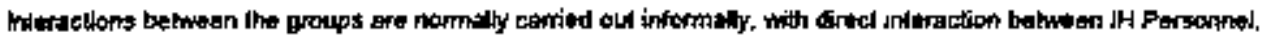

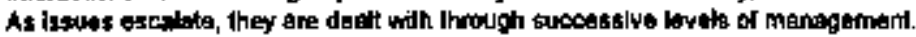

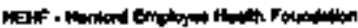

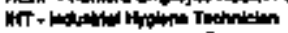

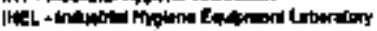

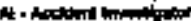




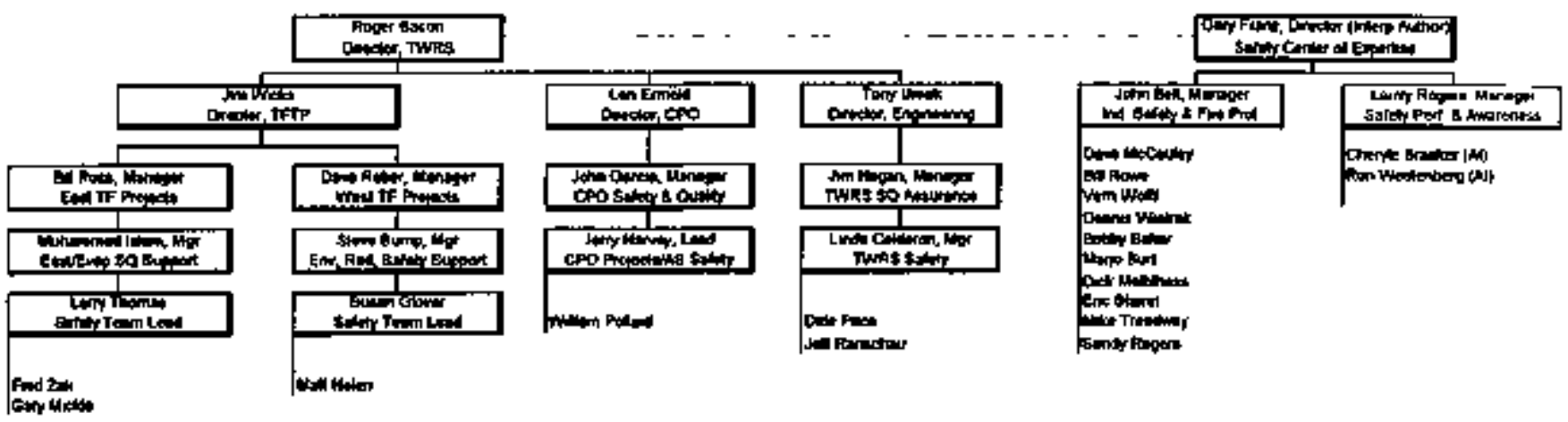

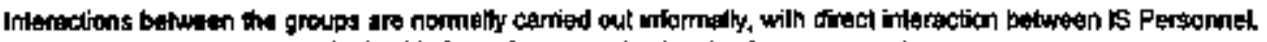

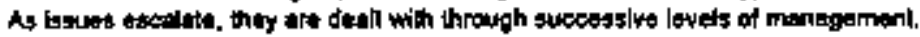


Fire Protection

TWRS Communication Interface

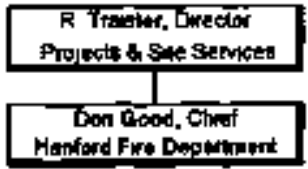

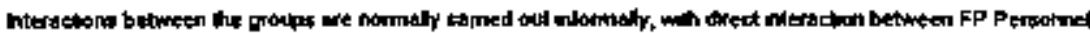

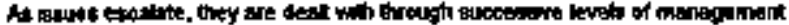

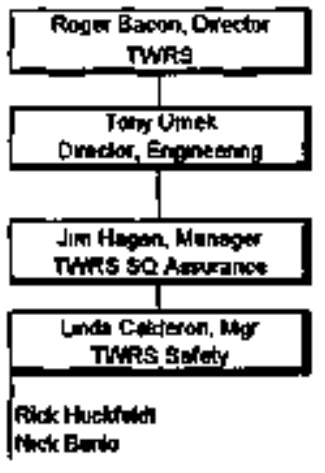

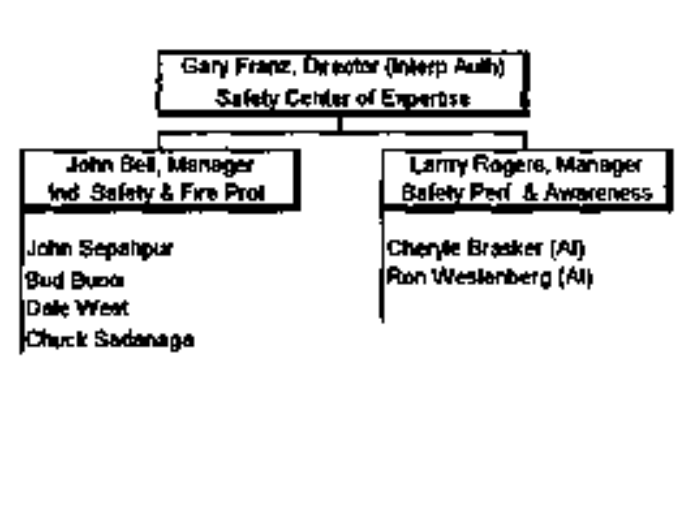




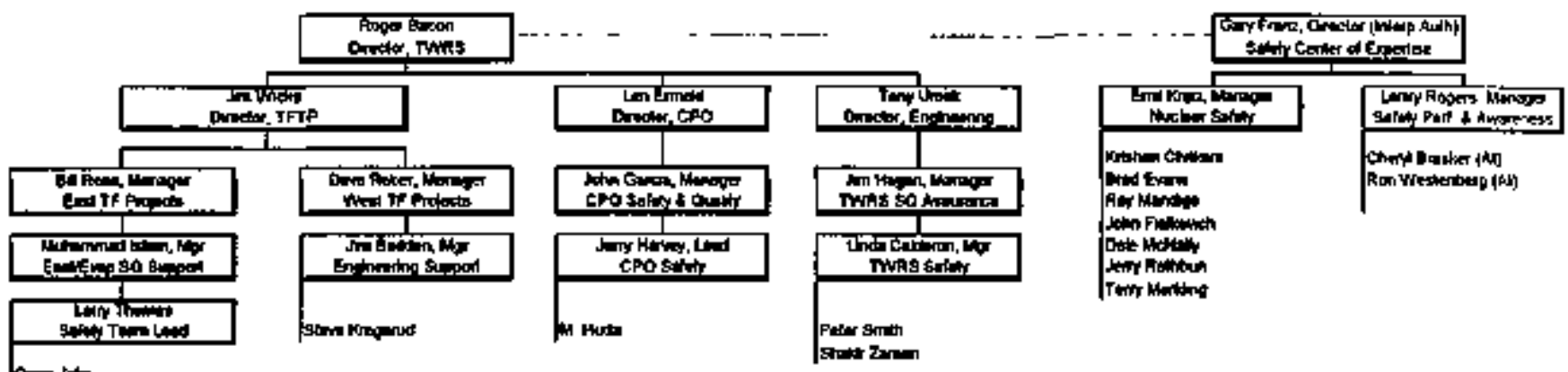

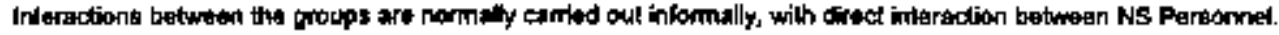

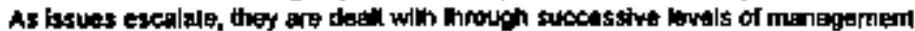


SAFETY CENTER OF EXPERTISE SUPPORT GROUPS

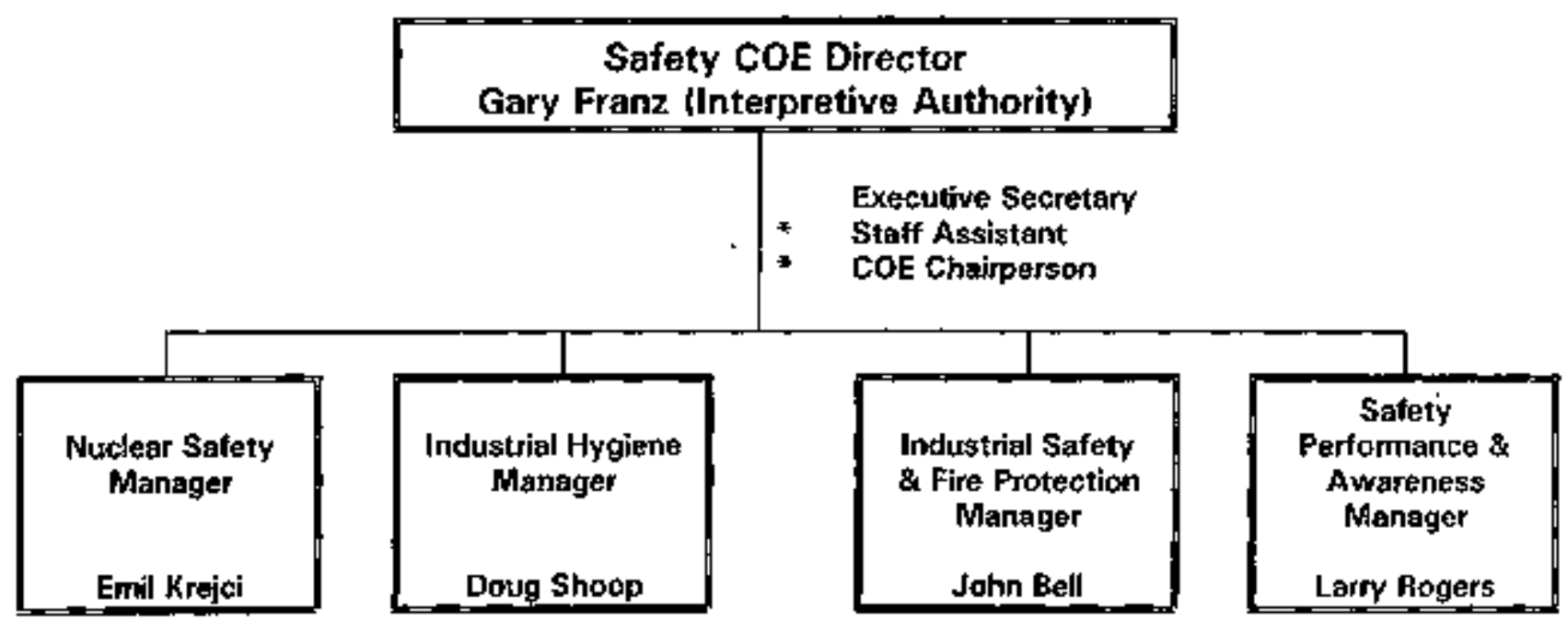




\author{
AWh]LABLE [HOUSTR]AL 5NFETY EQUIPMEST \\ Extendable mirrors with illumination \\ Hood head 3 prong testerfGfCl Tester \\ 25' 'Tape Measure \\ Conpass \\ Be?t Pac \\ Small, high totensity flashlight \\ Soft side chemical goggies \\ Solar Power Scientfic Calculator \\ Stopwateh \\ Șlurvoyor's Clipboard \\ 35 m Camera - Pentax 115 Zoom \\ Poloroid cacera - Captiva $5 E$ \\ WHS Vidon Camera - 8 am Sony
}

\title{
AYALLBLE JNDUSTR[AL HYGLENE EQULPHENT*
}

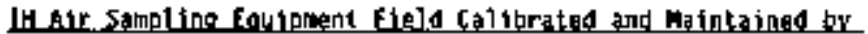

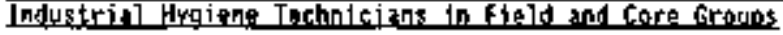

Industrial Sclentific 0,-LEL meter, Moddl MX 251

Industrial Scientific Sanpling Punp. Hodel SP-400

Thermo-Eny i ronmental Orgen ic Vapor Meter, Model 580

Industrial scientific Multigas Heter. Madel twX-4]0

पraeger \$ampling Puap, Nadel 31

Oraegar Sampling Pump, Model Accuro

Industrial Sclentific sanpling Punp, Model SP-202

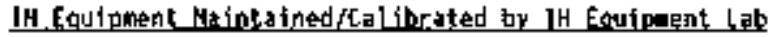

Therem-Enviromental Continuous Organic Atr Monitor, Model 52

Sentex Scentograph Gas Chronatograph

Foxboro Mirath Infrared Organlic antlyzer, Madel lax

Gilian Air sampling Pump

GenRed Sound Lave] Heter, Howdel 1980

GenRad Sound Leyel theter, hadel 1560

Quest Sound Level Meter, Madel 2700

Quest sound leyel Mater, Hodel 215

Simpson Light Meter

Extech Light Neter

Metrosonits Net Bulb 6lobe Thermoneter, Mods1 HS-360 (2)

Alnor Velomgter, Model 6000P

Hetrosonics Heat Stress Dosimeter (3)

Quest Heat Strest Dosineters

Metrasonies Wet Bulb Glabe Thermeneter. Mods1 HS-360 (4)

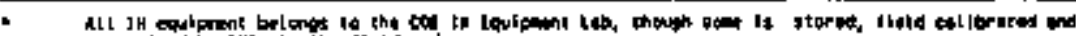

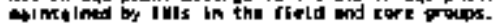




\begin{tabular}{|c|c|c|c|c|c|}
\hline 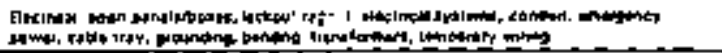 & & $x$ & & & \\
\hline 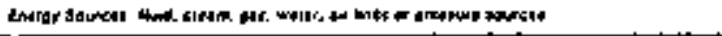 & & $x$ & & & \\
\hline 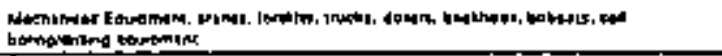 & & $-x$ & & & \\
\hline 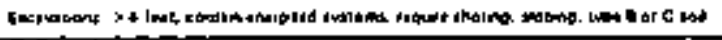 & & $x$ & & & 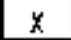 \\
\hline 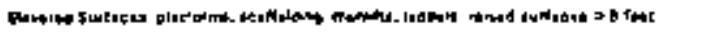 & & $x$ & & & \\
\hline 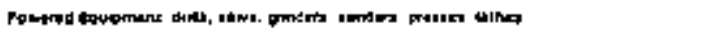 & & $x$ & & & \\
\hline 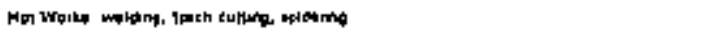 & & $x$ & $\alpha$ & & \\
\hline 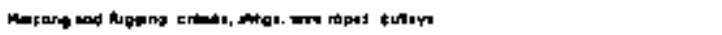 & & $x$ & & & \\
\hline 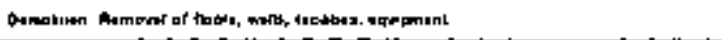 & $X$ & $x$ & $x$ & & $x$ \\
\hline 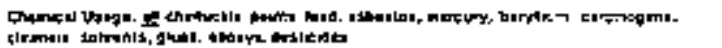 & $\chi$ & & $\mathbf{X}$ & & \\
\hline 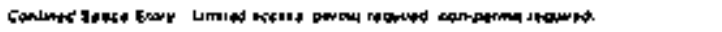 & $\not{h}$ & $x$ & & & \\
\hline 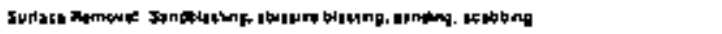 & \冖 & & & & $x$ \\
\hline 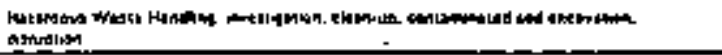 & ไ̌ & $x$ & & & $x$ \\
\hline 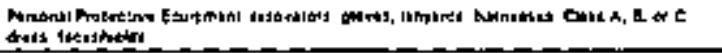 & $\mathrm{x}$ & X & & & $x$ \\
\hline 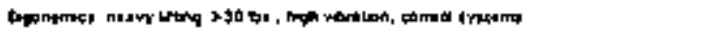 & $x$ & & & & \\
\hline 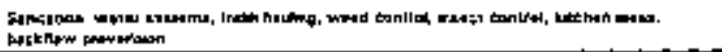 & $\mathrm{x}$ & & & & \\
\hline 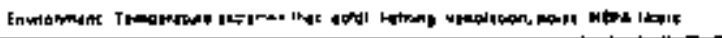 & & & & & \\
\hline 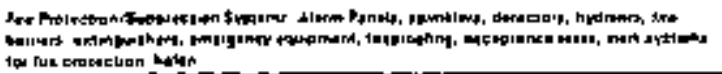 & & & 久 & & \\
\hline 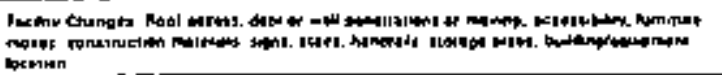 & & $X$ & $X$ & & 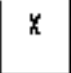 \\
\hline Fat Herend athempld & & & $\mathrm{X}$ & $x$ & $x$ \\
\hline Galored and Maters mpas & $x$ & X & $\mathrm{x}$ & & \\
\hline 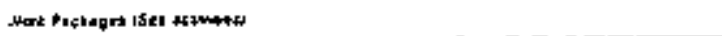 & & & & & \\
\hline 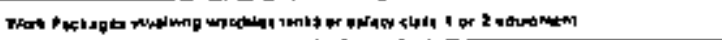 & & & $x$ & $x$ & \\
\hline nent to & & & & & \\
\hline
\end{tabular}

* Documents related to or invoiving radialogical control issues. aress or facilaties only

m. Fianduble oas wachlist tanks onily 


\section{COCGMEAT REW[EH MATR]'}

\begin{tabular}{|c|c|c|c|c|c|}
\hline ACIIYITIES. DOCLFERIS & {$[\mathrm{H}$} & is & FP & N5 & $\mathrm{F} \mathrm{C}^{*}$ \\
\hline \multicolumn{6}{|l|}{ 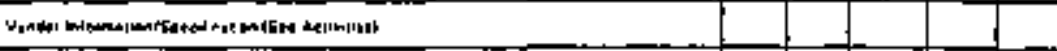 } \\
\hline \multicolumn{6}{|l|}{ 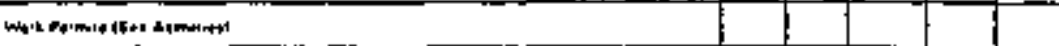 } \\
\hline 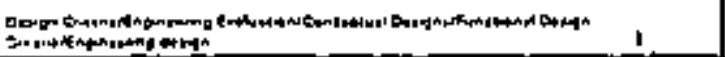 & $x$ & $\ddot{x}$ & $x$ & $\mathrm{x}$ & $x$ \\
\hline 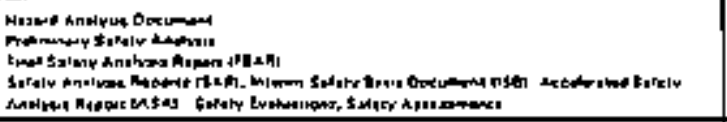 & $\mathbf{x}$ & Y & $x$ & 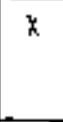 & $x$ \\
\hline 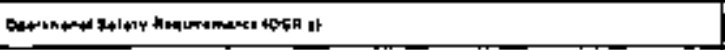 & & & $\mathbf{x}$ & $x$ & $x$ \\
\hline 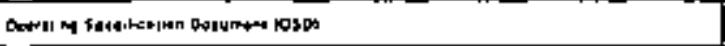 & & & 久 & $x$ & $\mathbf{y}$ \\
\hline 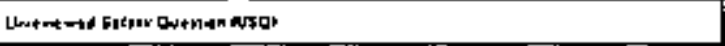 & & & & $y$ & $x$ \\
\hline \multicolumn{6}{|l|}{ 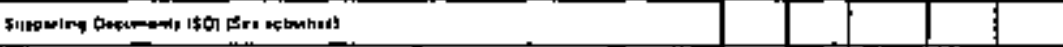 } \\
\hline \multicolumn{6}{|l|}{ 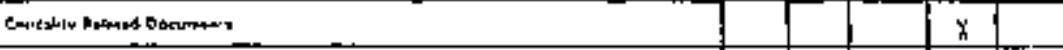 } \\
\hline Mar:l, & $\not$ & 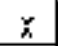 & $\mathbf{x}$ & қ. & $x$ \\
\hline 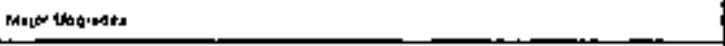 & $\Sigma$ & 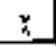 & 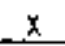 & $\mathrm{x}$ & $X$ \\
\hline Pags & & & & $x$ & $x$ \\
\hline \multicolumn{6}{|l|}{ 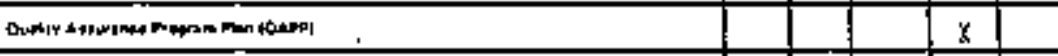 } \\
\hline 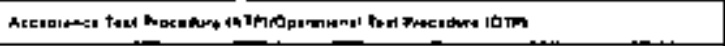 & $x$ & $x$ & $x$ & $y$ & $x$ \\
\hline \multicolumn{6}{|l|}{ 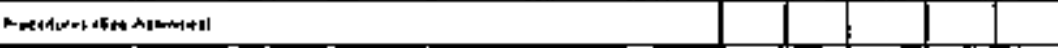 } \\
\hline \multicolumn{6}{|l|}{ 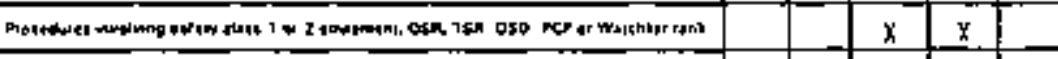 } \\
\hline 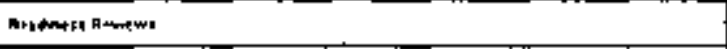 & $\mathrm{x}$ & i. & $x$ & $x$ & $x$ \\
\hline Wexil tranater & & & & $x$ & $x$ \\
\hline \multicolumn{6}{|l|}{ 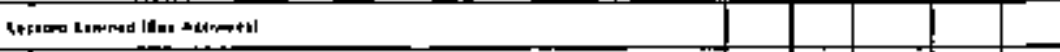 } \\
\hline 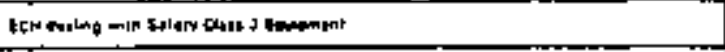 & $x$ & $x$ & & & $X$ \\
\hline 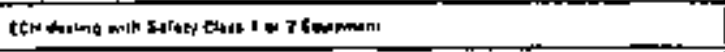 & & & $\mathbf{x}$ & 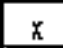 & $x$ \\
\hline 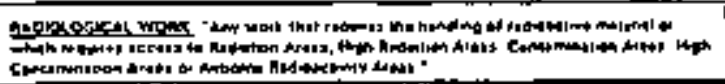 & & & & & $x$ \\
\hline
\end{tabular}

- Ooxuments rebated to or invalving rodiological control issues. arajs. Or raclities only. 


\section{TWRS SAFETY CORE GROUP ADIINISTRATION AND OVERSIGHT}

IMPLEMENTATION PLANSCHEDULE

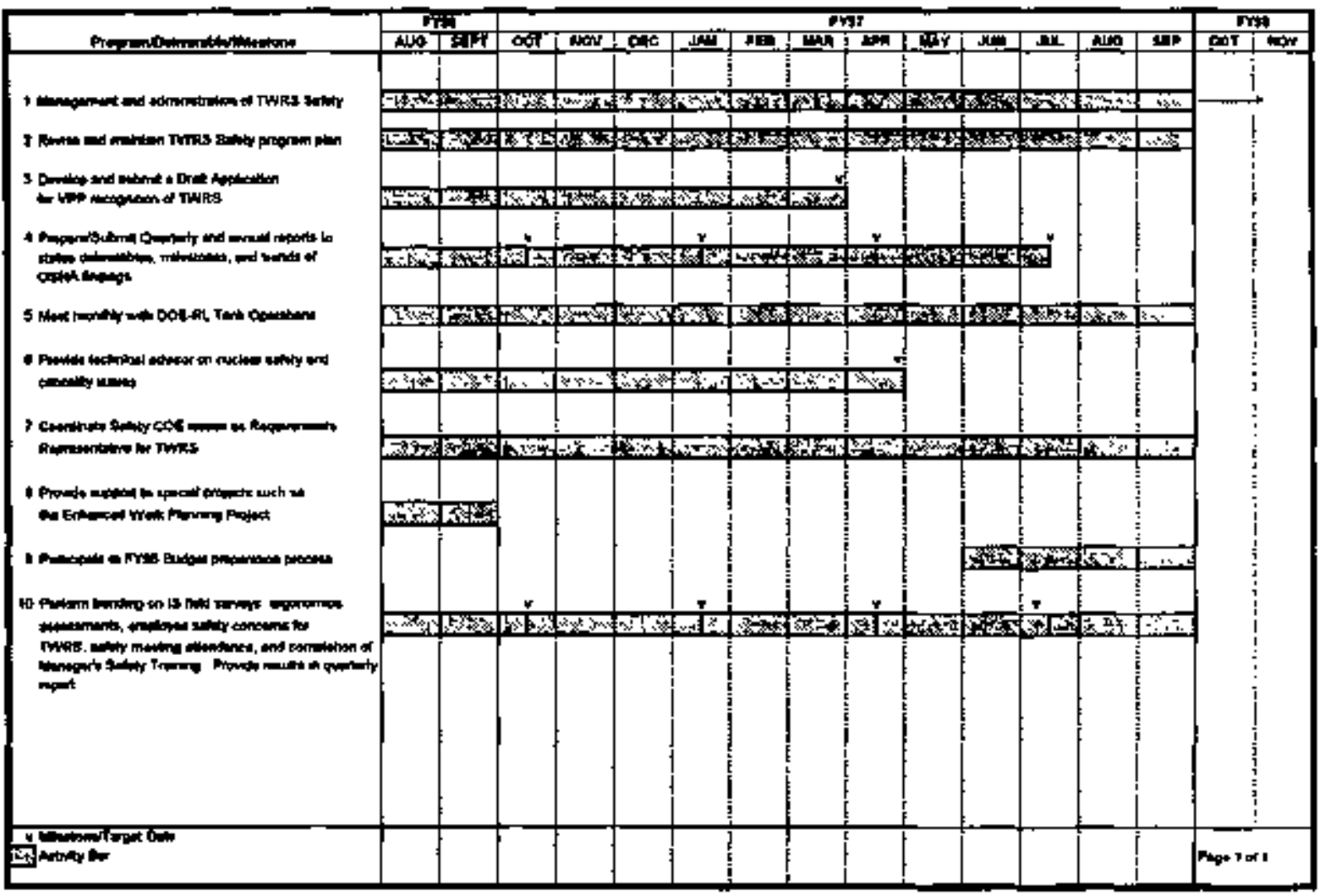


TWRS SAFETY CORE GROUP INDUSTRIAL HYGIENE

IMPLEMENTATKON PLANUSCHEDULE

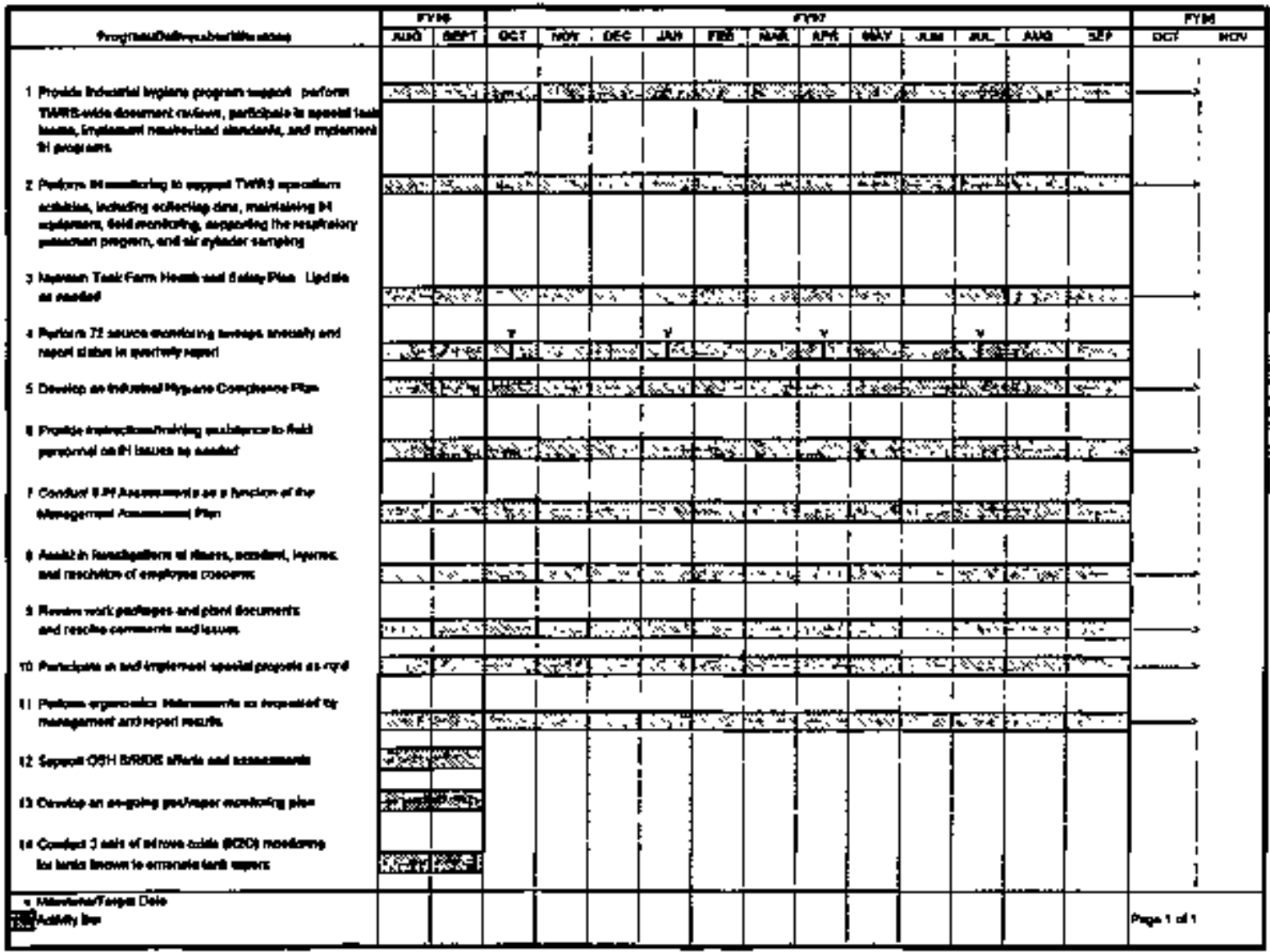




\section{TWRS SAFETY CORE GROUP INDUSTRIAL SAFETY IMPLEMENTATION PLANUSCHEDULE}

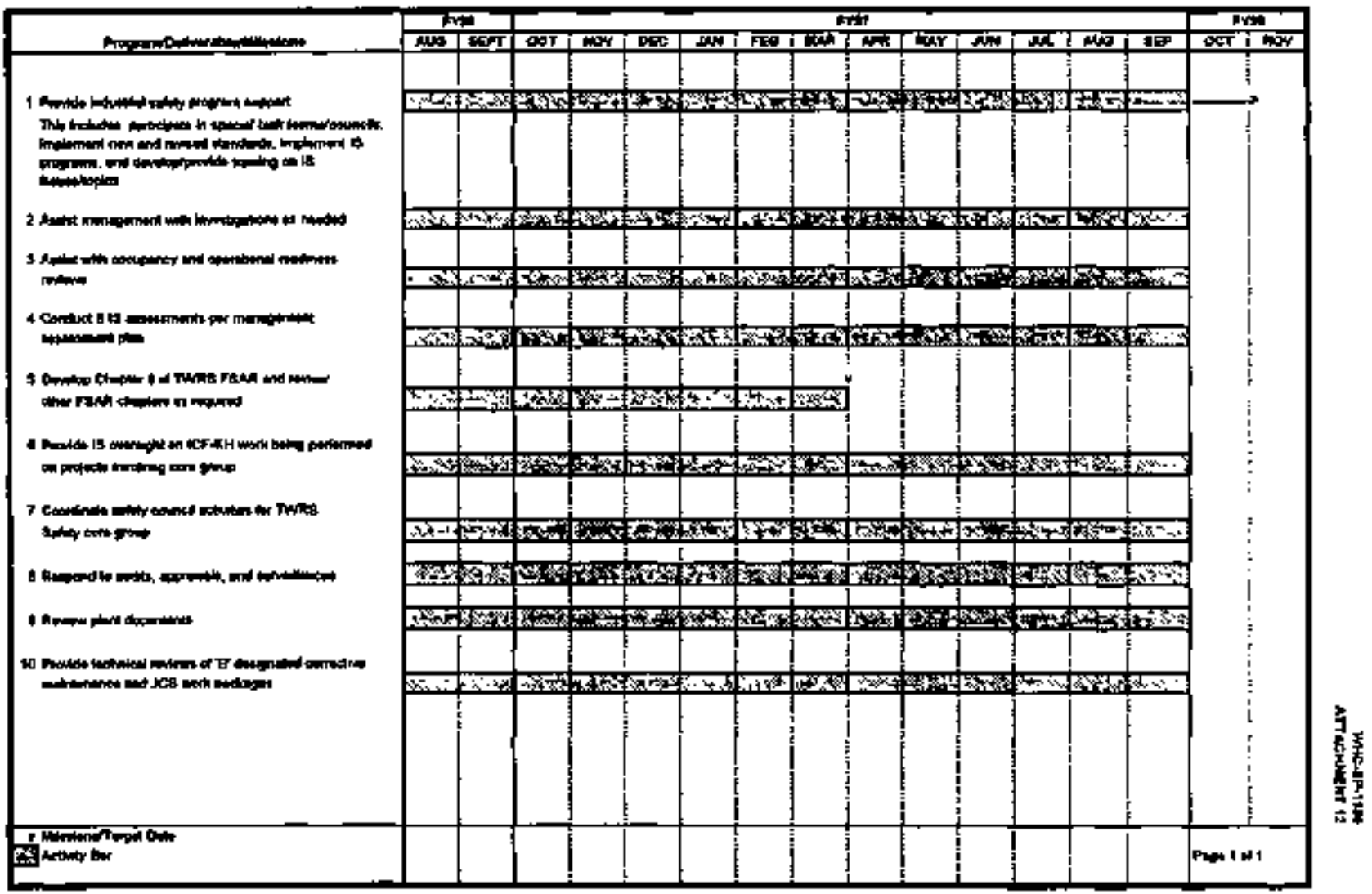




\section{TWRS SAFETY CORE GROUP FIRE PROTECTION}

IMPLENENTATION PLANUSCHEDULE

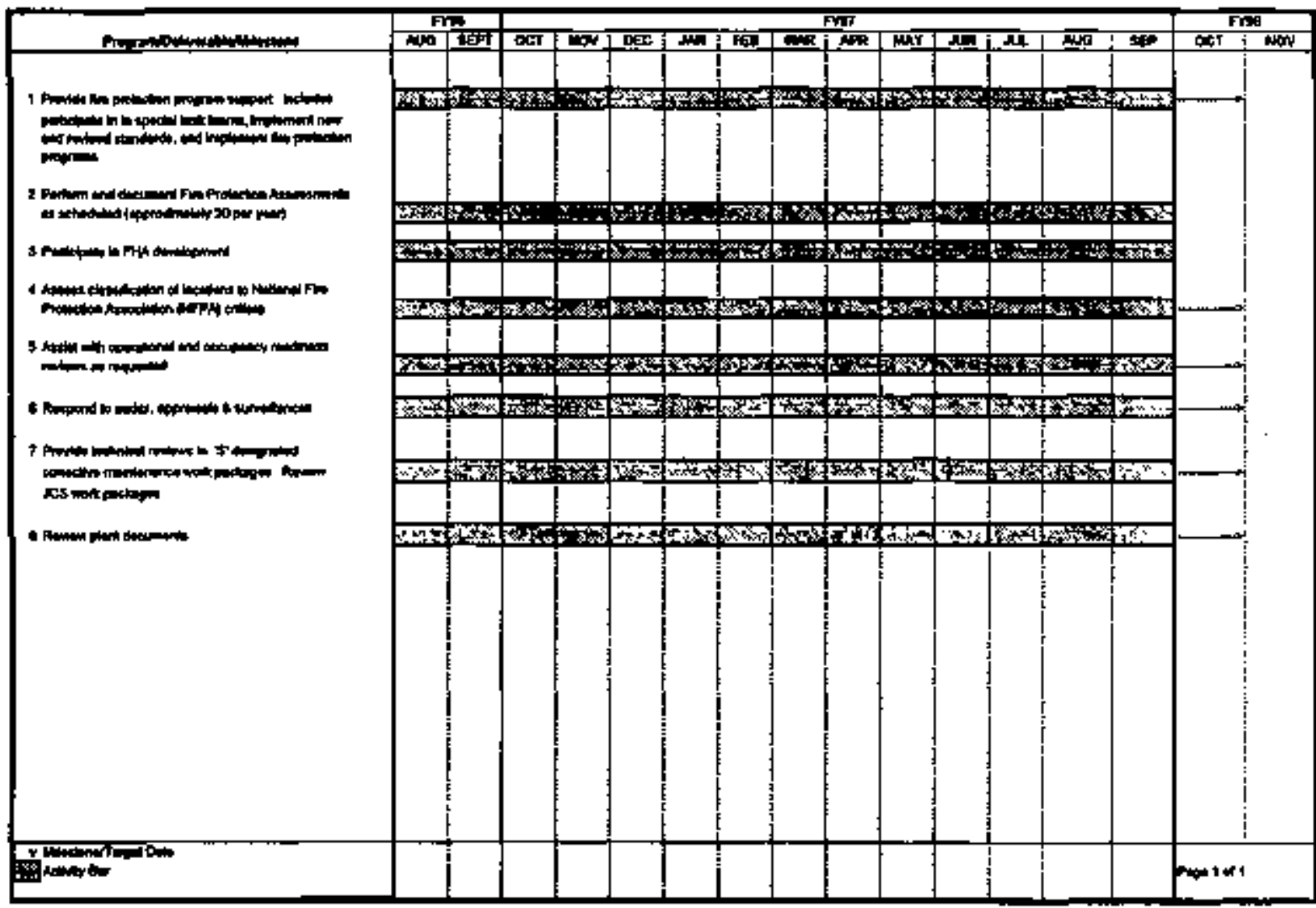


TWRS SAFETY CORE GROUP NUCLEAR SAFETY TMPLEMENTATION PLANISCHEOULE

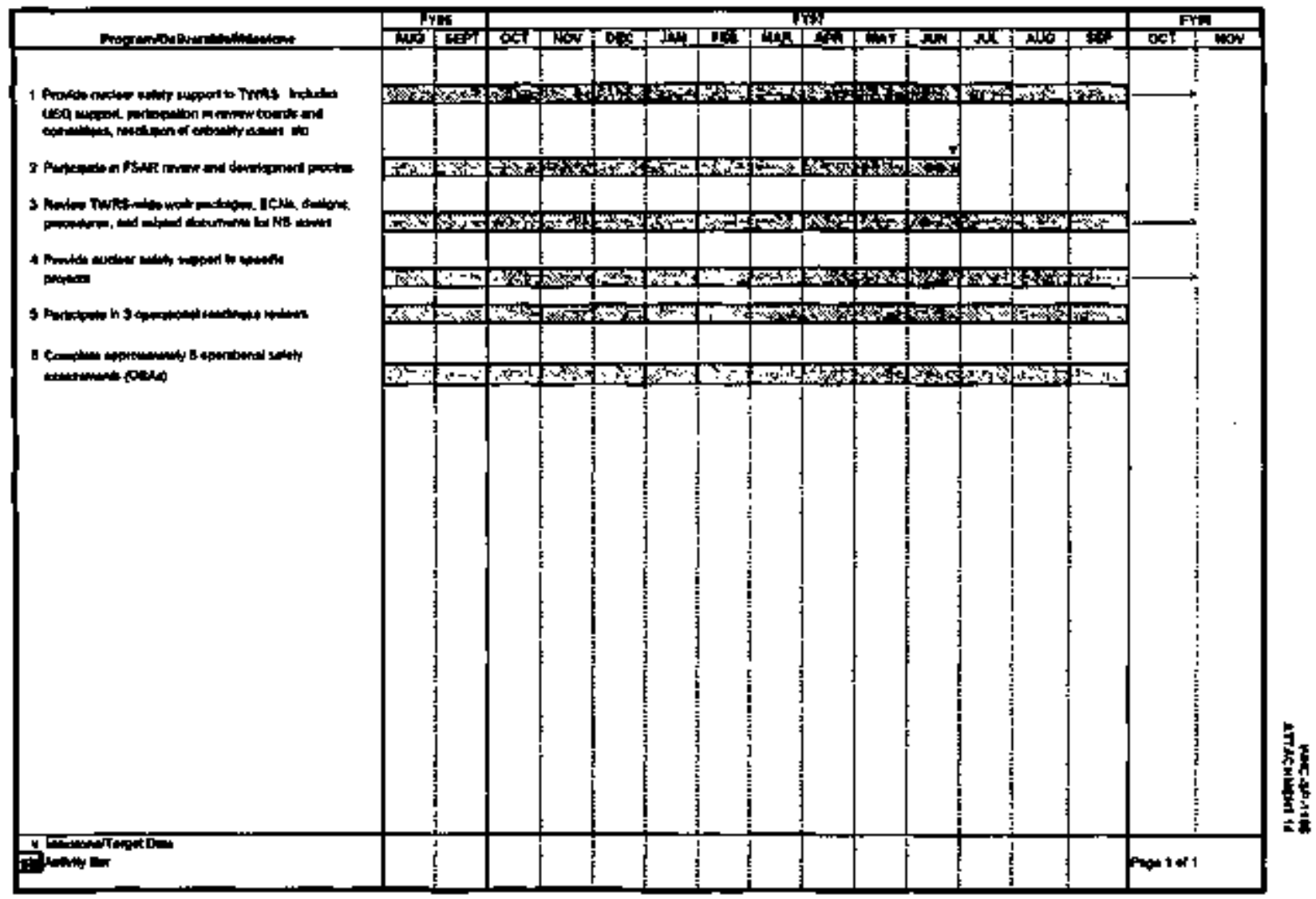


ANALYTICAL 5ERICES SAFETY

PROJECTED BASELITHE MORXLOAO

\begin{tabular}{|c|c|c|c|c|c|c|c|c|c|c|c|c|c|c|c|c|}
\hline \multirow[b]{2}{*}{ PRONECTEP WORKLDADا' } & \multicolumn{3}{|c|}{ FY 96} & \multicolumn{11}{|c|}{ FY का } & \multirow[t]{2}{*}{ FY9: } & \multirow[t]{2}{*}{ FYg9 } \\
\hline & $10 \pi$ & $\mathrm{A0O}$ & step & OCT NOW & DEC & $\mathbf{I A N}$ & FEB & ANR & ATR & MAY & נUN & JUL & AUR & SES & & \\
\hline Paperwotk Revions & $\begin{array}{c}x \\
12\end{array}$ & $\begin{array}{c}x \\
12\end{array}$ & $\begin{array}{c}x \\
100\end{array}$ & $\begin{array}{cc}x & x \\
0: & 0\end{array}$ & $\begin{array}{l}x \\
0:\end{array}$ & $\begin{array}{c}x \\
08\end{array}$ & $\begin{array}{l}x \\
08\end{array}$ & $\begin{array}{c}x \\
08\end{array}$ & $\begin{array}{c}x \\
08\end{array}$ & $\begin{array}{l}x \\
0 \text {. }\end{array}$ & $\begin{array}{c}x \\
0 B\end{array}$ & $\begin{array}{c}x \\
05\end{array}$ & $\begin{array}{l}x \\
05\end{array}$ & $\begin{array}{c}x \\
08\end{array}$ & \begin{tabular}{c|}
$x$ \\
0.8
\end{tabular} & $\begin{array}{c}x \\
0 *\end{array}$ \\
\hline 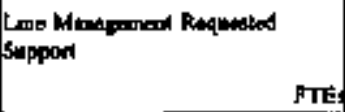 & $x$ & $\begin{array}{l}x \\
05\end{array}$ & $\begin{array}{l}x \\
05\end{array}$ & $\operatorname{lis}_{0 .}^{x} \times$ & $x$ & $\begin{array}{l}x \\
05\end{array}$ & $\begin{array}{l}x \\
05\end{array}$ & $x$ & $\underbrace{}_{05}$ & $\begin{array}{l}x \\
05\end{array}$ & $\begin{array}{l}x \\
015\end{array}$ & $x_{0 .}^{x}$ & 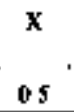 & $\begin{array}{l}x \\
05\end{array}$ & \begin{tabular}{l|}
$x$ \\
05
\end{tabular} & $\begin{array}{l}x \\
05\end{array}$ \\
\hline 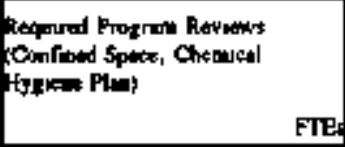 & 01 & $\begin{array}{l}x \\
01\end{array}$ & 01 & $\begin{array}{ll}x & x \\
01 & 01\end{array}$ & $\begin{array}{l}x \\
01\end{array}$ & 01 & $\begin{array}{l}x \\
01 \\
0\end{array}$ & $\begin{array}{l}x \\
0\end{array}$ & $\begin{array}{l}x \\
01 .\end{array}$ & $\begin{array}{l}x \\
0 !\end{array}$ & $\begin{array}{l}\mathbf{x} \\
\mathrm{aT} \\
\end{array}$ & $\begin{array}{l}\mathrm{x}^{.} \\
0 \mathrm{I}\end{array}$ & $\begin{array}{l}x \\
01\end{array}$ & $\begin{array}{l}x \\
01\end{array}$ & Q L & 01 \\
\hline 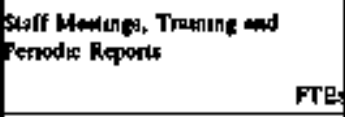 & $\begin{array}{l}x \\
02\end{array}$ & $\begin{array}{l}\mathbf{x} \\
02 \\
\end{array}$ & $\begin{array}{l}x \\
02 \\
2\end{array}$ & $\begin{array}{l}x \quad x \\
02 \quad 02 \\
\end{array}$ & $\begin{array}{l}\mathbf{x} \\
\mathbf{0 2} \\
\end{array}$ & $\begin{array}{l}x \\
02\end{array}$ & $x$ & $\begin{array}{l}x \\
02\end{array}$ & $\begin{array}{l}x \\
02\end{array}$ & $\begin{array}{l}x \\
02\end{array}$ & $\begin{array}{r}x \\
02 \\
\end{array}$ & $\begin{array}{l}x \\
02 \\
\end{array}$ & $\begin{array}{l}x \\
02\end{array}$ & 02 & 02 & $\begin{array}{l}x \\
02\end{array}$ \\
\hline Audı Support & $\begin{array}{l}x \\
01\end{array}$ & $\begin{array}{l}x \\
01 \\
\end{array}$ & $\begin{array}{c}x \\
01 \\
\end{array}$ & $\mid \begin{array}{ll}x & x \\
01 & 1\end{array}$ & $\begin{array}{l}x \\
01 \\
\end{array}$ & $\begin{array}{c}x \\
01\end{array}$ & $\begin{array}{r}x \\
01 \\
\end{array}$ & $\begin{array}{l}x \\
01\end{array}$ & $\begin{array}{c}x \\
01\end{array}$ & $\begin{array}{l}x \\
01\end{array}$ & $\begin{array}{c}x \\
01\end{array}$ & $\begin{array}{c}x \\
01\end{array}$ & $\begin{array}{l}x \\
01\end{array}$ & $\begin{array}{l}x \\
01\end{array}$ & $\begin{array}{c}x \\
0 .\end{array}$ & $\begin{array}{l}x \\
01\end{array}$ \\
\hline 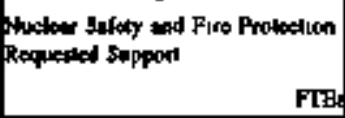 & $x$ & $\begin{array}{l}x \\
02\end{array}$ & $\begin{array}{l}x \\
02 \\
\end{array}$ & $\int_{02}^{x}: x$ & $\begin{array}{l}x \\
02\end{array}$ & $\begin{array}{l}\mathbf{x} \\
02\end{array}$ & $x_{2}$ & $\begin{array}{l}x \\
02\end{array}$ & $\begin{array}{c}\mathbf{x} \\
02\end{array}$ & $\begin{array}{l}x \\
02\end{array}$ & $\begin{array}{l}x \\
02\end{array}$ & $x_{2}^{x}$ & $\begin{array}{c}\boldsymbol{x} \\
02\end{array}$ & $\begin{array}{l}x \\
0 z\end{array}$ & $\begin{array}{l}x \\
02\end{array}$ & $\begin{array}{l}x \\
02\end{array}$ \\
\hline TOTAL PTE & 23 & 23 & 21 & 1919 & 19 & 19 & 19 & 19 & 19 & 19 & 19 & 19 & 19 & 19 & 19 & 19 \\
\hline FTEs Bodgone. & 22 & 22 & 22 & $22 \quad 22$ & 22 & 22 & 22 & 22 & 22 & 22 & 22 & 22 & 22 & 22 & 22 & 22 \\
\hline PTEs Awillate for Podh Forwari & +.1 & 4.1 & 0.1 & $4.3 \div 3$ & $\mathbf{t . 3}$ & 6.3 & $\bullet$ & 0.3 & $\omega$ & 0.3 & $\mathbf{0 . 3}$ & 1.3 & 13 & 4 & 0.3 & 0.3 \\
\hline
\end{tabular}

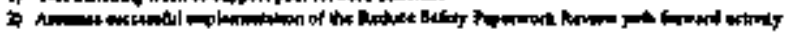


HLALYICAL SERYICES SAFETY

PATH FORNARD ACTIVITIES IHPLEKEKTHTION PLAN/SCHEDULE

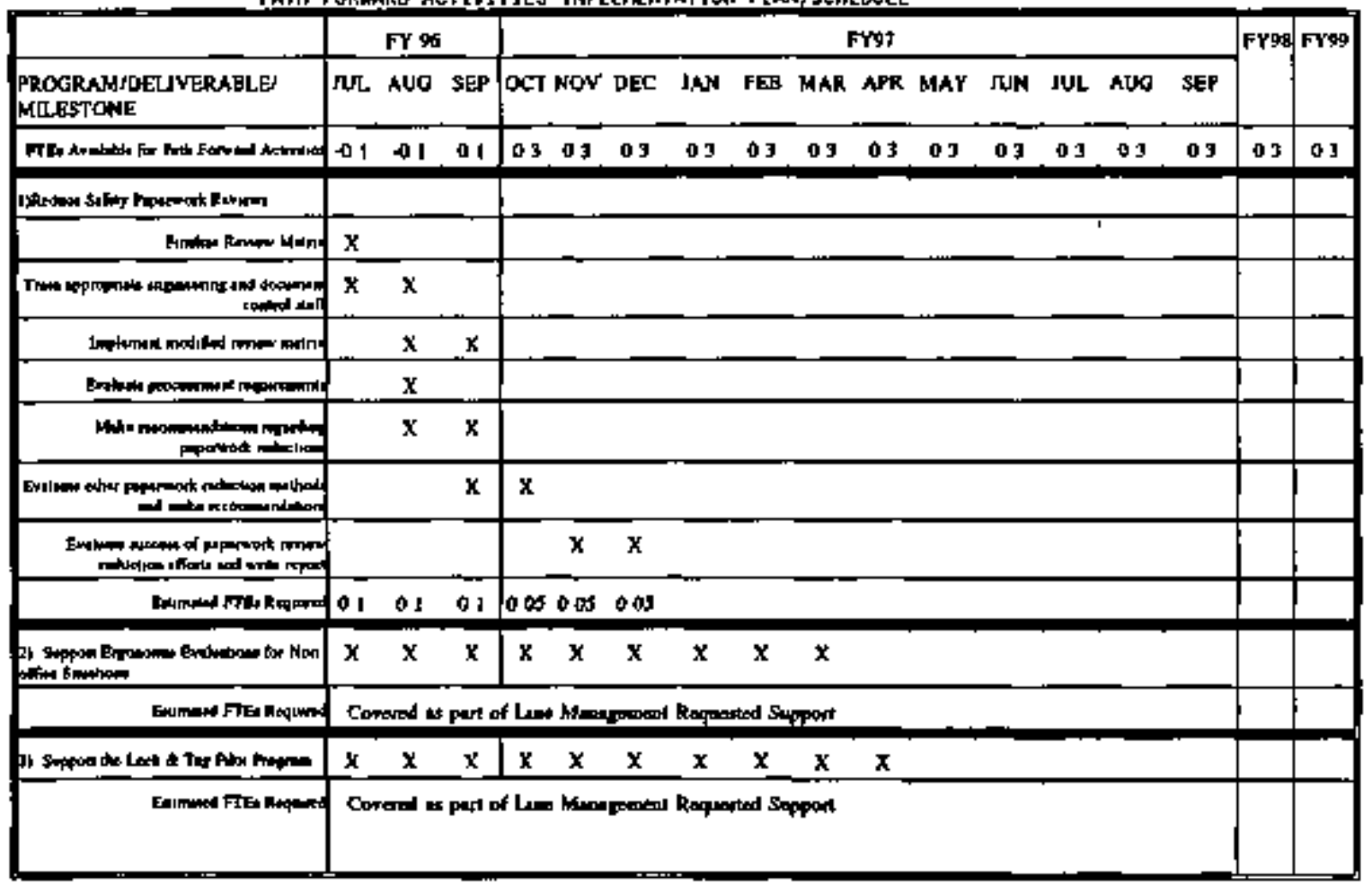


ANAYTICAL SERYICES SAFETY

PATH FORHARD ACTIYITIES INPLE EEMIMT JOH PLAH/SCHEDULE

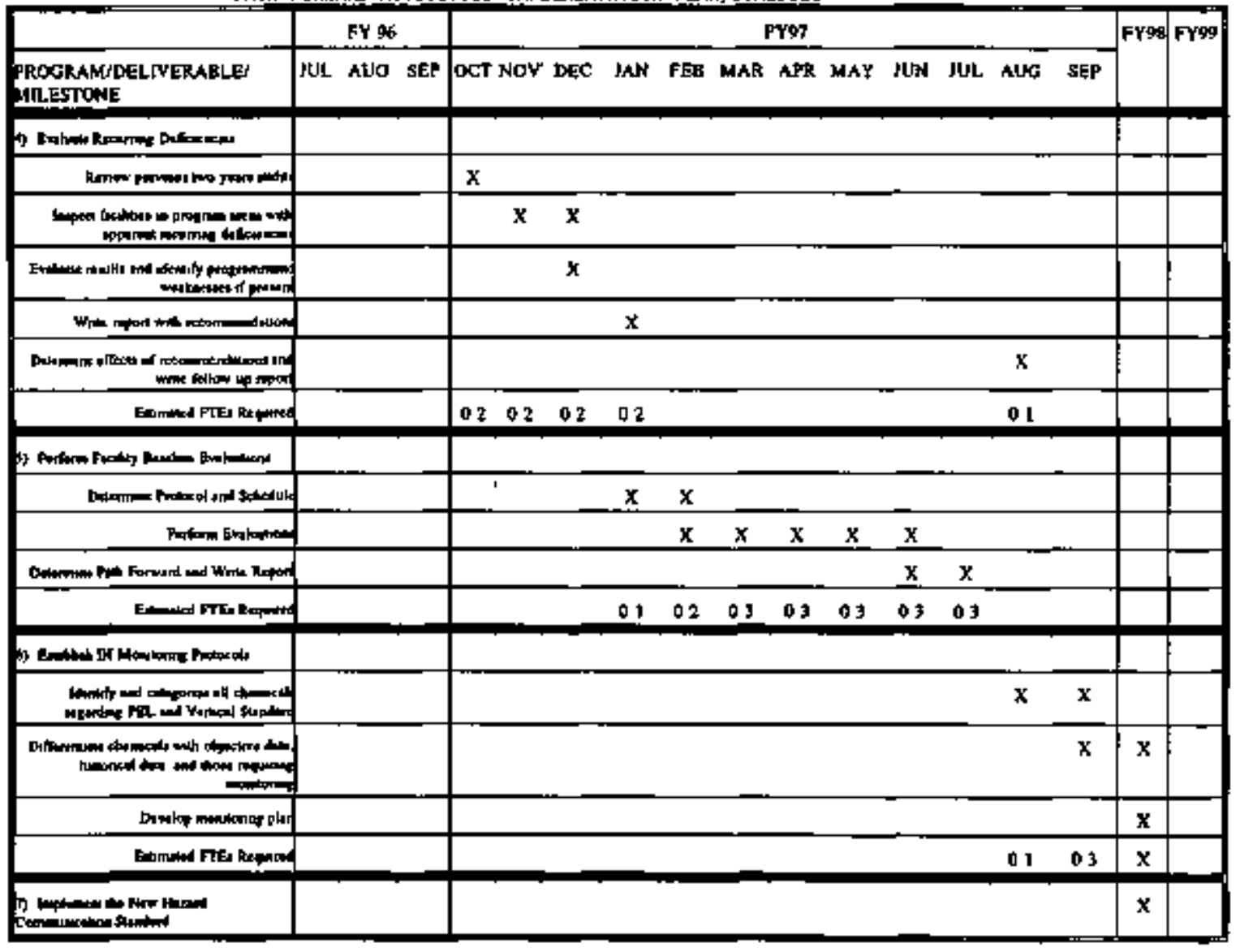


ANALYTICAL SERVICES SAFETY

FULL TIME EQUIVALENT SUMMARY

\begin{tabular}{|c|c|c|c|c|c|c|c|c|c|c|c|c|c|c|c|c|}
\hline \multirow[b]{2}{*}{ ACTIVTTY } & \multicolumn{3}{|c|}{$5 Y 96$} & \multicolumn{11}{|c|}{ FY 97 } & \multirow[t]{2}{*}{ Frged } & \multirow[t]{2}{*}{ Frg9 } \\
\hline & لإبا. & AUG & SEP & act Mor & DEC & JAN & FEB & MAR & $A P R$ & MAY & Iț & JuL & Alk & SEP & & \\
\hline Current Wortalond PTEs & 25 & 23 & $2 t$ & 1519 & 19 & 19 & 19 & 19 & 19 & 19 & 19 & 19 & 19 & 19 & 19 & 19 \\
\hline $\begin{array}{l}\text { I) Reduce Safedy Papermott } \\
\text { Roviows }\end{array}$ & 01 & 01 & 01 & 005005 & 005 & & & & & & & & & & & \\
\hline 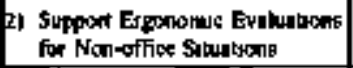 & \multicolumn{14}{|c|}{ Covered ad part of Lina Mmangenent Requeded Shpport } & & \\
\hline 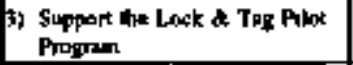 & \multicolumn{14}{|c|}{ 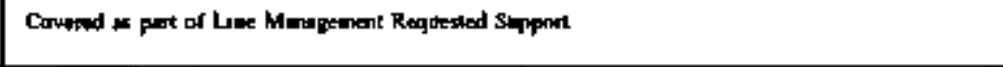 } & & \\
\hline 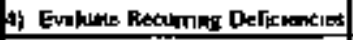 & & & & $02 \quad 02$ & 02 & 02 & & & & & & & 01 & & & \\
\hline $\begin{array}{l}\text { 5) Perform Futduy Bnoline } \\
\text { Exatuationt }\end{array}$ & & & & & & 01 & 02 & a & 03 & to 3 & 01 & 03 & & & & \\
\hline 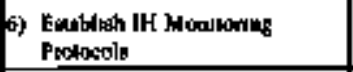 & & & & & & & & & & & & & of 1 & 03 & $\mathbf{x}$ & $x$ \\
\hline 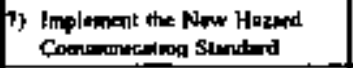 & & & & & & & & & & & & & & & $\mathbf{x}$ & $\mathbf{x}$ \\
\hline TOTAL FIE: & 24 & 23 & 22 & $215 \geq 15$ & 215 & 22 & 22 & 22 & 22 & 22 & 22 & 22 & 21 & 22 & $x$ & $x$ \\
\hline FTt Bedpeldod & 22 & 22 & 22 & 2222 & 22 & 22 & 22 & 22 & 22 & 22 & 22 & 22 & 22 & 22 & $\mathbf{X}$ & $x$ \\
\hline 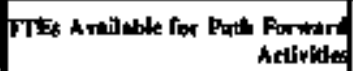 & -12 & $A 2$ & $\mathbf{A}$ & A.ts b.s & 0.05 & 06 & tet & 1.t. & to & 10 & 0.0 & 50 & 0.1 & 10 & $\mathbf{x}$ & $x$ \\
\hline
\end{tabular}




\section{SAFETY COMMUNICATIONS}

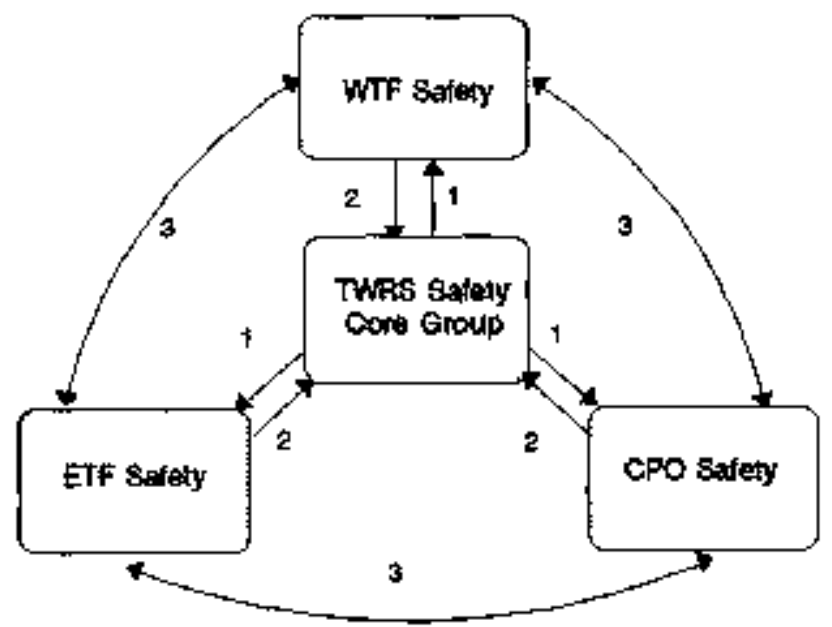

Communlcalion Link 1

- External or genization hilormation

- Reguirements/Regulation changes (info from COE)

- Program impiementetion stralegies

- TWRS-wide training programe

- Input to facllity required reading program

- Trending information

Communiostion Link 2

- Provide inpul tor quarterly reports lo DOEJThS menegement

- Input on liedd aoflvities ior DOE Interface, SubTAP, and external commitees.

- Keep core toam imlermed on fleld sadety issues

- Forward ste safelyfargonomic survey into lo core lor 1rending

- Personal monitoring regulta

Communioation LInk 3

- Exchango ideas on solying saiely issust

- Addrass oonsislency and application of programs for applicalion in the tient

In addition to the above, salety porsonnel atlend Hartort-wide mealings for proiesstongls whin each disolpling. 


\section{COMMUNICATIONS WITH EXTERNAL ORGANIZATIONS}

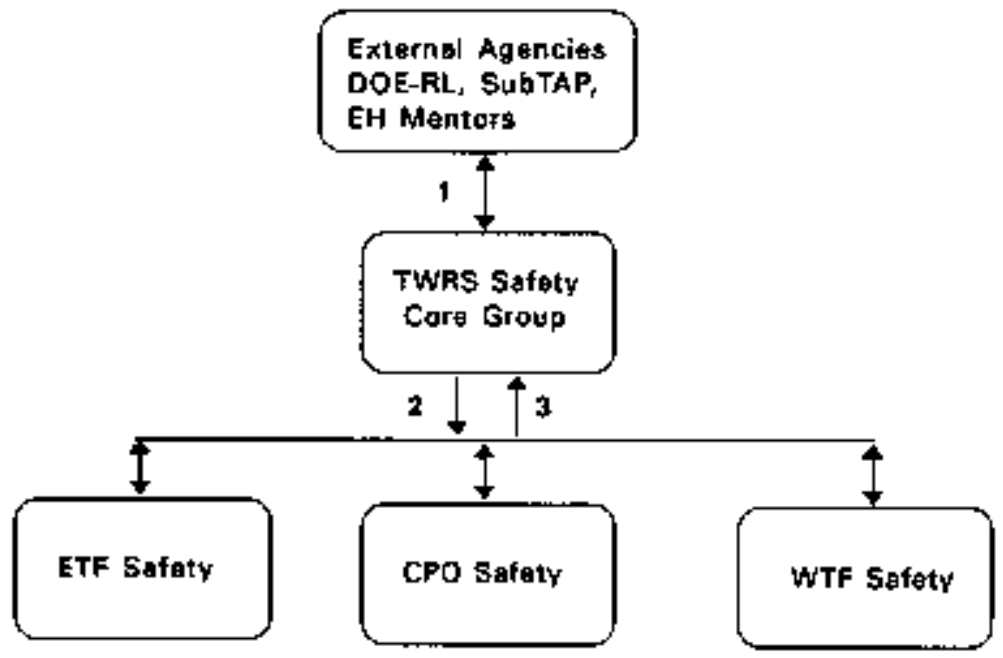

Communication Link ?

- Core to provide interface with organizations external to TWRS. This includes DOE-RL (feports and interface megtings), SubTAP ICoordingte meeiling, presentstions, and responses to recommendations]. EH Mentors (Work with mentors to resolve TWRS safety issues\}, and perticipate in safety related councils and committess (DNFSE, PAPC, PAC. etc.l.

\section{Communication Link 2}

- Relay intormation to field personnal from DOE-RL, EH, SubTAP, safety committees. and other toxiernal agencias.

\section{Communication Link 3}

- Provida input on field ectivitios and safety lsswes for inclusion in Ouarterly Rtport, DOE Interfece meetings, SubTAP sessions, and sofety committoes. 


\section{SAFETY CENTER OF EXPERTISE COMMUNICATION CHANNELS}

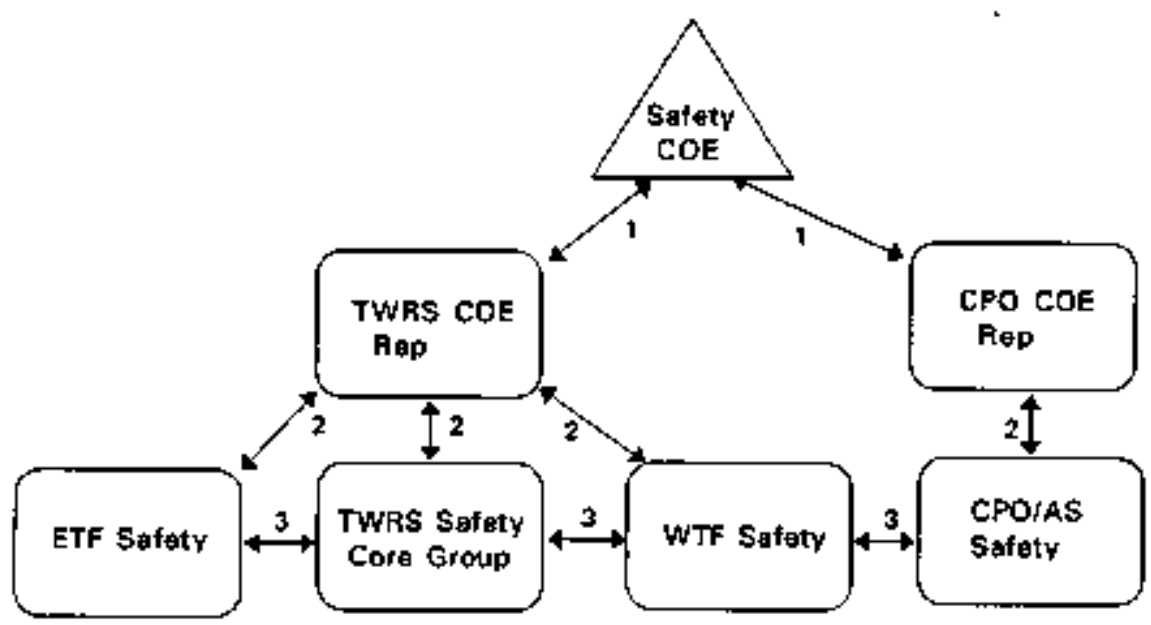

Commundestion LInk 1

CDE representatives provide the interface between TWR5 and CPO and the Safty Center of Experrtse. Topics of uxchange Includt:

- Hantarof-wide pregram difections

- Ropulatiandraquirement charges

- Sile satetr Inlianilves

- Field itsues with posential sho-wide impact

r Trending of sately dats

Communle日tion Lisk 2

- COE Reps wall conmunicote infomation to tank fam field, core anf CPO selety personnel through cemait, formal memos. phosk. or required reading programt. is wpropriets.

- Fenk Farm field. cora, and CPO safety personnesl will provide indormalion on TWRS gafety kague $B$ to the CDE through the represemalive.

Communiçatgan Unk 3

- CPO. fiald. and cor antety parsonned ensure conslsreni aragram Implementarian throughout TWAS.

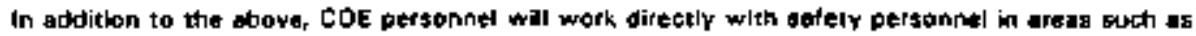
documant and program reviews and incident/eccidenl invegtipations. 


\section{DOCUMENT REVIEW FLOW DIAGRAM}

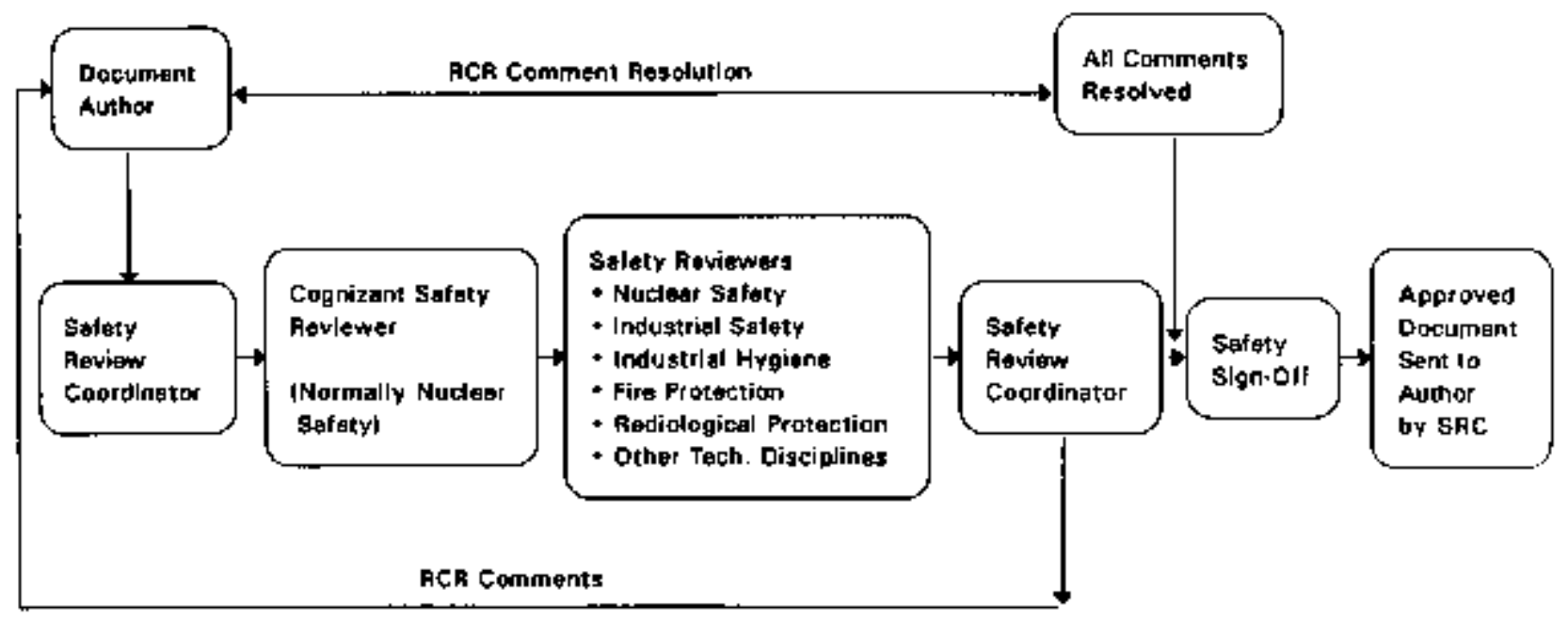




\section{The}

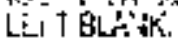


Wh-5P-1185, Rer, O

\section{DISTRIEAT ]UN}

\section{Humbar of conoles}

\section{ONSITE}

26 Meftinghouse Haford Congar

\begin{tabular}{|c|c|}
\hline 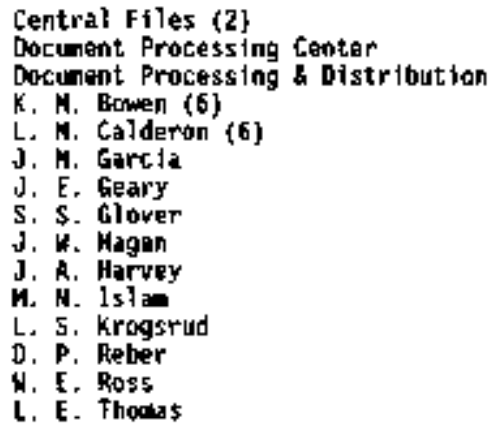 & \\
\hline
\end{tabular}


inivi.

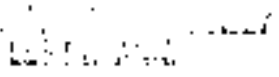

